Keywords: North Carolina; Mewboorn: Mewborn; Newborn; Newbern; Palatine; early American settlers

\section{Tracing Early American Settlers: Mewboorn and Mewborn Origins}

\author{
Ian G Macdonald
}

Abstract: This monograph is a study of a family of early settlers in North Carolina. It follows a single family from its progenitor in the early $18^{\text {th }}$ century and traces seven generations of descent. The progenitor's origins are explored; family myths critically examined; possible links to the Palatine migration of 1710 considered. Wills, court records and land transactions are used to establish relationships and confirm identities in the $18^{\text {th }}$ century. Census records from 1850 and burial records, particularly from findagrave.com, have enabled later generations to be well characterised as have published family bibles in some lines of descent. A mapping technique has been employed to trace family development, and migration, between 1790 and 1840 when censuses indicate numbers, ages and sex of household members, though with only the head named. Patterns in these censuses have been used in developing hypotheses for identity leading up to the full naming provided from 1850 .

Descent from the progenitor, Thomas Mewboorn, is traced in stages through 56 family trees covering the seven generations.

A strength of this paper is that it shows what can be achieved today in American genealogy by using online sources only. The study has been carried out from the UK. This may also be a weakness, and searches in American archives may be able to shed light on some areas of hypothesis. That, however, is how science progresses. It does not invalidate what has been done so far.

\title{
Introduction
}

The Mewborns are recognised as members of the Order of First Families of North Carolina, ${ }^{1}$ having been there before it became a royal colony in 1729.

This monograph describes descent from Thomas Mewboorn of North Carolina, the progenitor of the Mewborn family in Carolina and the United States of America.

The name is variously rendered. Mewboorn is the earliest form but that gave way to the more easily spelt Mewborn. Some found Newborn easier still. Unfortunately, that is a fairly common name in England, so those name holders can be confused readily with unrelated later settlers. Others speaking Germanic languages often changed a 'Neu' prefix to 'New' and no doubt felt that being Newborn in a new land was an appropriate start. Newbern is often used too, particularly among descendants of Nicholas, Thomas's eldest son. Fancier spellings also appear - Mewborne, Mewbourn or Mewbourne, and the same with an ' $\mathrm{N}$ ', but these can come and go. Note that Hanks Dictionary of American Family Names makes little attempt to explain Mewborn and Mewbourn saying simply "English: unexplained. Perhaps a variant of Newborn. This name occurs frequently in NC...".2

There is no right or wrong to these - a person can be called whatever they choose. Insistence on any particular spelling is foolish (though government agencies will disagree). The important thing is to recognise that any of the variants can turn up and that change can take place from generation to generation. It complicates the tracing of descent but that is just part of the fascination of genealogy. The researcher has to learn to relax and under no circumstances be dogmatic about the nature of the names.

( 2020 The Author(s). This is an open access article distributed under the terms of the Creative Commons Attribution License (http://creativecommons.org/ licenses/by/4.0/) 
The study does, however, follow the name, in whatever form it takes, down the male line of descent from Thomas Mewboorn and the lines from his six sons. The six lines give the monograph its structure. It is not well balanced. A couple of lines are particularly prolific, one is almost non-existent. Poor, or non-existent, records in the late $18^{\text {th }}$ and early $19^{\text {th }}$ centuries leave gaps where descent cannot be demonstrated immediately. Some more recent Mewborns cannot be linked back to Thomas. They have the name but lack provenance. One day additional family bibles or testamentary records may turn up that provide evidence of links that at present are uncertain. If that happens then new editions of this work may appear.

The descent from Thomas that is offered here is based largely on cited primary sources, so can be fairly relied on. Elsewhere, many chunks of family tree have been published online, placed by family members. Unfortunately, most are flawed by their failure to cite sources or, worse, by copying or citing other flawed trees. Those chunks will mostly have been derived by a historian of the family working back from the present (and usually running out of steam when the backward links are not apparent). This study moves forward in time from Thomas using the evidence that records offer. The structure is therefore sound though, as suggested, there may be a few offshoots that have been missed - but not many, I hope. The monograph covers the first seven generations - members of the seventh generation being identified but not fully characterised. That tends to take things some way into the $20^{\text {th }}$ century so it should be relatively straightforward for any present-day descendants to fill the gap to themselves. I hope that proves to be the case.

A number of secondary sources are cited in this work and references given as endnotes. This has not been done, though, for the multitude of facts which support the many trees drawn to show the descent, and that illuminate the modest amount of the main text. However, all of the references (around 1,700 of them) can be found in the online tree hosted by the Guild of One-Name Studies at https://mewborn.one-name.net.

Please note that this is not a family history. It does not offer much by way of insights to the lives and doings of the characters who appear, and the communities they lived in; it is simply an unravelling of descent, an attempt at resolving the complexity, confusion and obscurity that surrounds the Mewboorns. The resolution is considerable though still partial, but the task has been fun. The author is completely unrelated to the Mewboorns and has taken them on just for the hell of it. Carpe diem, quam minimum credula postero.

\section{The Start of it All}

This first part seeks to add clarity to the origins of the Mewborns and to provide a defined foundation, constructed from historical facts, on which to develop a sound structure for the family's descent and spread during its first 200 years or so. It examines possible origins, describes what is known about Thomas Mewboorn and his children, and discusses an analysis of early census records and how that may shed some light on the Dark Ages between 1750 and 1850 where records are thin on the ground.

By setting aside myth, legend, wishful thinking and romantic longing for noble origins, a clearer and more plausible story can be allowed to emerge that is just as remarkable in its own way. It illustrates the early development of the USA and the realities of that process.

\section{Origin and origin myths}

\section{The England myth}

The Mewborns are known first from Carolina and North Carolina where lines can be traced from a Thomas Mewboorn who died in 1749 at Bertie County, NC. A will that year provides hard evidence for him and members of his family. The question that arises, though, is When did he first arrive there?

Carolina gained its first permanent British settlement in 1653 on the Albemarle Sound at the mouth of the Chowan and Roanoke rivers. However, there is nothing to indicate any Mewborn presence in those earliest days. As we will see, the best we can suggest is that it may have started around the time of the division in 1710 that formed North and South Carolina - so an early $18^{\text {th }}$ century origin.

The first myth, found in some family lore and in Pedigree Resource Files on www.familysearch.org, is that Thomas was born around 1699 in Northumberland, England to a Moses Mewburn. However, no evidence is put forward for this claim in any of the places it is offered. The claim is also repeated in various trees on Ancestry.com, though still with no supporting evidence. In a variation on the theme, Marjory Oliver states in her history of The Suttons of England and North Carolina ${ }^{3}$ that Thomas was born in England in 1668 but, once more, offers no evidence though, thankfully, makes no claim for where he was from or who his father might have been.

The English Mewburns, Meburns and Meaburns have been well studied. ${ }^{4}$ Extensive searches show no record of a Thomas being born in Northumberland around the relevant time, and there is even no record of any English Mewburn (prior to 1895) ever having been called Moses ${ }^{5}$. There is no evidence, therefore, of an origin in England. Later we will see that Thomas Mewboorn may have arrived in the Americas by way of England and that subtlety may have been lost in subsequent oral transmission. 
A possible cause for at least the Moses part of the myth is that researchers may have accepted an error in Ancestry.com records. Searches produce an index record with a probate date for a Moses Mewborn at Bertie on the $3^{\text {rd }}$ of October $1719^{6}-$ apparently pointing to someone who, given that death date, might have been from the mid- $17^{\text {th }}$ century. In fact, this index record is linked to the will of Thomas's son Moses written on the $3^{\text {rd }}$ of October 1766, and which achieved probate in March 1767. There is no 1719 will and, therefore, no evidence of an early Moses.

The Moses myth is also perpetuated in The Descendants of Moses Mewboorn of England. ${ }^{7}$ That 'book' offers no evidence in what is a poorly researched, descendant report (that even omits most Newborns and all Newberns) in which hardly any meaningful sources are cited. Little credence can be attached to it.

Popular legends

If the Mewborns or Mewboorns did not come from England then where did they come from, and how does that name come to be in the USA? At least three views have been expressed.

One theory relates to the early history of North Carolina. The Mewboorns lived in counties (Bertie, Chowan, Edgecombe, Dobbs, Lenoir) inland and north of the first state capital of New Bern. That town gets its name from Swiss settlers who arrived at roughly the same time as the Palatine migrants in 1710. The Swiss had great difficulty in securing tenure at New Bern and some eventually moved inland to those areas where the Mewboorns are first found (areas - spun-off from the early Albemarle County - lightly colonised much earlier by English settlers coming down from Virginia). This raises the possibility that names such as Mewboorn and Mewbern were corruptions of New Bern. So, was the first Moses, if he did exist, actually Swiss? Well, no. As it happens, Thomas Mewboorn can be shown to have been in place at Bertie no more than six years after New Bern was founded in 1710. It seems highly improbable, therefore, that the name was adopted from the new town and almost immediately given a corrupt spelling (even more so if the Collins commentary given later is correct and the original town name was Neuse Bern, after the river on which it was built.).

Mrs John Bennett Boddie's version of the name's origin, in her Historical Southern Families ${ }^{8}$ is, however, intriguingly different. She says:

The first Thomas Newbern (spelled variously Newborn, Mewborn, or Newboorn) came from the vicinity of Heidelberg in Germany, on the river Neckar, in the Grand Duchy of Baden. Because of the religious persecutions of the time, he migrated to England with about 12,000 other persons and from thence to North Carolina, where he settled in New Bern. In 1716, Thomas Newbern bought land in the area which is now Edenton, Chowan County, North Carolina.

This tale is clearly based on the real migration of the Palatines (some of whom may indeed have come from Heidelberg though the total catchment area was much larger). This is discussed later and, incidentally, was economically inspired and was only peripherally to do with religion ${ }^{9}$. However, Boddie then gives 1704 as the birth year for Thomas, which would make him twelve years old when she claims he was buying land. The use of Newbern (and Newborn, Mewborn and Newboorn) in Boddie's work is also a slanted treatment. When we look at original records, we find that Thomas and his children use only the Mewboorn spelling in their wills. These wills are the only documents we have for them that they were specifically responsible for creating. The wills are also the only documents found that carry their signatures, and invariably they sign as Mewboorn. Subsequently it is particularly the line derived from son Nicholas in which the Newbern spelling is used consistently. It was a choice they made in that line, but there is no historical precedent for it.

There is yet another version of the origin set out by Bonnie McCarthy in 2015 in the Public Member stories section on Ancestry.com. It appears in material largely devoted to the John Parrott Gray family, and their Bible (and which also favours the ' $N$ ' spelling). There the ancestor becomes 'Anton Thomas DeGraffenreid Newbern Mewborn'10 - a remarkable name and one that certainly covers most of the bases, though obviously nonsensical. Her account is as follows:

It has been handed down on my husband's father's side of the family that our Newbern name came about because of two brothers who fought and went their separate ways. Baron Christopher de Graffenried and Thomas were those brothers. Thomas decided to take the name of the new town that his father Christoph de Graffenried had named here in the new world, the town of New Bern North Carolina, after his home in native Bern Switzerland. This was something for the time as the de Graffenried name had been honored for centuries. Father Christoph returned to Bern Switzerland and the Baron and Thomas stayed and made their home here. According to the pamphlet "History of Deraffenreit Mewborn, Newbern and Kindred Families" by Cora L Newbern and A Dewey Newbern ${ }^{11}$ the will of Thomas Mewborn (Newbern) dated 23 Feb 1749 was the first to bear the name. The will was probated Nov 1749 at Cashey Bridge, Albemarle, North Carolina. The name was signed to the original will and in bold legend scrawled across the page in their grandfather's old bible, "I and my family shall hence forth be known as 'Mew Born'. So the descendants who write the name Mewborn are following his example and those that write it Newbern are following what was his intent. Thomas did not append the apellation "Gentlemen" to his name as was the custom among those of gentle birth nor did he affix the Seal which doubtless bore the motto of the deGraffenrieds. That seal handed down from father to son along the senior line for generations was kept by their grandfather in a wooden box which contained the old family bible which accompanied the founder (Christoph) and first ancestors to America. While their grandfather was bedridden in the last months of his life the seal disappeared. His widow who survived him by many years, grew old and the bible, a rare edition was discovered to be missing. This was after 1921 . She believed it was stolen by a male black servant who knew its value to a collector. There were many pages of "de Graffensriedt" in the bible. It was remembered that I was the 18th generation to be on its family record. (I do not know if the "I" above is A Dewey Newbern or someone else as Dewey was born in Dec 1898). 
This is a profoundly confused account. The published history of the DeGraffenreid family (although suffering from overblown purple prose), ${ }^{12}$ and its description of the establishment of the New Bern colony by Christophe, makes no mention of any Thomas or of a dispute between any DeGraffenreid brothers. There was no need, therefore, for anyone to take a new name, particularly the confection offered.

The comment about Thomas's will, and the Mewborn (Newbern) spelling, is also wrong. An image of the will is available online. The name Mewboorn is the only spelling used in the will. Thomas signed the will as Mewboorn (evidently, he could write his name) and it was witnessed by his son, Thomas, who also signed as Mewboorn. Neither signed themselves as 'gentleman' simply because they were not, and because they had no link to the DeGraffenreids. Orally transmitted evidence, as offered by McCarthy, of something supposedly written on a missing family bible is not sound evidence. The tale is too fanciful.

The spelling may, however, be important (though spelling was a fairly fluid matter in general at the start of the $18^{\text {th }}$ century). It is a fact that all members of the family in the first two generations used the Mewboorn spelling for their names when their wills were written. In some cases, this continued in use into the middle of the $19^{\text {th }}$ century in wills for later generations. The double ' $\mathrm{o}$ ' is distinctive. It is not often seen in English name spellings but is common in the Netherlands and adjacent areas, such as Schleswig-Holstein.

Incidentally, there is no known original list of the Swiss settlers who arrived in 1710. A compilation of names has been attempted at the New Bern Library (though its list is not claimed to be complete) ${ }^{13}$ and an earlier list was published in the North Carolina Genealogical Society Journal. ${ }^{14}$ The names on these lists are clearly Germanic, as one would expect, and none is even vaguely like Mewboorn.

\section{Historical Context}

A more likely origin for the Mewboorns is that they were part of the extraordinary migration of 'Palatines' that led to over 10,000 people arriving in England in 1709 (presumably the migration referred to by Boddie). The Palatines were notionally from the middle Rhine area - the Palatinate - but the double ' $o$ ' spelling of names is not found there. However, the migrants were joined by other disadvantaged folk as they made their way down the Rhine to the coast so, ultimately, some of the 'Palatines' were not from the Palatinate.

The principal shipments of people to England took place from Rotterdam. Many ended up in tents on the Blackheath and Camberwell commons around London and they became the subject of a major migrant crisis in England at that time. ${ }^{15}$ The crisis was resolved by shipping them onward to lands with capacity. It helped that the recently formed Britain was then a colonial power. Some 3,000 were shipped to New York in 1710 while others were sent to Ireland and a few hundreds, more relevantly, to Carolina.

The picture is complicated, however, by an addition of Swiss settlers to the 'Palatines', facilitated by Christoph DeGraffenreid. A useful summary of this migration, and the Swiss aspect, has been given by Donald Collins: ${ }^{16}$

The idea of a settlement in Carolina was conceived by Georg Ritter and Company of Bern, which saw an American colony as an opportunity to profit from mining ventures in the New World and financial grants from the Bernese and English governments for transporting the settlers to Carolina. The company purchased 10,000 acres between the Neuse and Cape Fear Rivers from the Carolina Proprietors, who offered the land at a low price. Graffenried himself purchased 5,000 acres and was given a title of nobility in the colony under the feudal system designated by the Fundamental Constitutions of Carolina. He also assumed direction of the entire project.

In January 1710 the Palatines sailed from Gravesend under John Lawson, surveyor general of Carolina, while Graffenried himself remained in England to await the Swiss. They endured an overly long voyage of 13 weeks, during which more than half of them died from close confinement, meager provisions, spoiled meat, and other hardships. Off the coast of Virginia, one of the ships, filled with supplies, was plundered by a French privateer. These misfortunes were followed by a fever epidemic when the Palatines reached land.

The survivors proceeded to the Chowan River, where they purchased supplies from planter Thomas Pollock, and then traveled through the sounds to the Neuse River. Lawson settled them at the fork of the Neuse and the Trent River. During the summer, almost all fell ill, and many sold their clothes to English settlers in the area in return for food.

When Graffenried arrived with the Swiss, he acted swiftly to relieve the situation. Adequate supplies were unavailable locally as a result of instability created by the Cary Rebellion, so he sent to Virginia and Pennsylvania for provisions. In order to avoid friction with the Indians, Graffenried paid them for the same lands that he had already purchased from the Carolina Proprietors. He then began to develop the settlement which he called Neuse Bern, or Bern on the Neuse. This was later corrupted by the English into the present name, New Bern. Lots of 250 acres, located primarily along the Trent River, were assigned to families, while artisans, including carpenters, blacksmiths, and shoemakers, were to reside in town. Graffenried designed the town in the shape of a cross, with the intention of placing a church in the center. After a shaky beginning, the settlement began to prosper; the combined total of Swiss and German settlers was approximately 400.

Graffenried fell deeply into debt and was unable to obtain provisions for his settlement. He returned to England in 1713, hoping to borrow funds. Unsuccessful, he gave up his colony as a failure. The Palatines lost their lands to Pollock, who assumed ownership as Graffenried's chief creditor. In 1749 they were granted equivalent lands, which were spread out over an extensive area, thereby effectively dispersing Graffenried's original settlers. 
The small number of settlers remaining, after losses due to disease, war, and the hardships of the ocean voyage, intermarried with residents of other nationalities, and the Swiss-German community blended into the population at large. Their family names, however-including Metz (Metts), Kernegee (Kornegay), Eibach (Ipock), Mueller (Miller), and Kuntz (Koonce)-are still prominent in eastern North Carolina.

As a further twist to the migration story Wikipedia notes that "Parliament discovered in 1711 that several "agents" working on behalf of the Colony of Carolina had promised the peasants around Frankfurt free passage to the plantations". ${ }^{17}$ Thomas might well have heard of this.

The most complete scholarly treatment of the Palatine shipments and the Swiss settlers at New Bern is that carried out by Rohrbach. ${ }^{18}$ His careful compilation of known names again shows nothing remotely resembling Mewboorn among the Swiss or other migrants and settlers mentioned.

No certainties emerge from all these accounts, though the possibility that Thomas Mewboorn was part of the Palatine migration seems high. Thomas could readily have joined the flow as the migrants passed through the coastal regions of north Germany and the Netherlands, where double 'o' name spellings can be found. However, having discussed this matter with noted Dutch genealogists (John Boeren and Yvette Hoitinck) the naming issue is more complex. The 'boorn' suffix could be from the Low Countries, but is uncommon, and the prefix 'Mew' is not known there (though 'Mee' is quite common). The whole name does not appear in the Dutch Database of Surnames (http://cbgfamilienamen. $\mathrm{nl} / \mathrm{nfb} / \mathrm{index}$.php?taal=eng). The only name in use at the period that is vaguely similar is Meijboom though it is a bit of a stretch to get from that to Mewboorn. Yvette noted that a search of German sources at http://meta.genealogy.net/for $M^{*}$ born shows the names Maiborn, Mayenborn, and Meyborn as possible candidates, but again the transition to Mewboorn is not obvious.

It should also be noted that in the North Carolina Historical and Genealogical Register the vast majority of names appear to be of English origin so Mewboorn is all the more curious.

The conclusion is that the name seems more Germanic than Dutch. Maybe then, Schleswig Holstein is the most likely point of origin and some unconvincing initial attempt at anglicisation may have led to Mewboorn? Or did Thomas invent his name on arrival in his new homeland? The mystery remains.

Lists of names of Palatine migrants have been created, ${ }^{19}$ though like the Swiss list, they are likely to be quite incomplete. The names, again, are clearly Germanic, but none bears even a distant resemblance to Mewboorn. The same is true of Palatines who were sent to New York, ${ }^{20}$ and of lists compiled for those on some of the ships used in transporting them. ${ }^{21}$ That absence of a comparable name can be interpreted either as meaning that Thomas was not a 'Palatine', at least not one from the Rhine Palatinate, or that he simply did not remain with the other immigrants once reaching the colonies. It also seems unlikely that Thomas Mewboorn had much to do with the New Bern settlement. He was long settled in Bertie while the Swiss and German Palatines were still struggling to gain any entitlement to land.

That is not to say that he might not have been involved in the early stages of developing the town. His skills as a blacksmith would have been valuable and he may have been indentured for a period after his arrival to supply those skills. The New York Palatines were noted, though, for resenting the notion of indenture, and attempts to hold them to it failed. ${ }^{22}$ It is possible that Thomas did work for a period deploying his skills and saving his earnings until, from 1716 , he was able to start buying land. That, though, is simply another hypothesis that may never be proved.

\section{Thomas Mewboorn, his children and grandchildren}

Thomas Mewboorn is known best from the will he left in 1749 at Bertie in North Carolina. He tells us he was a blacksmith, but he was also by then a plantation owner. However, when did Thomas first appear in North Carolina?

We might hope for a clue in the Order of First Families of North Carolina ${ }^{23}$ which apparently aims to give a sound account of those early times. It gives this brief comment on Thomas's land transactions:

Thomas purchased land in Chowan Co., NC, on 30 Mar 1722 from William Smith and his wife Rachel, 30 acres on the Sound called Hardy's Old Field, adjoining Thomas Pierce, Jr., Alexander Smith, and Henry Cogdale, according to Chowan Co., NC Deed Book C\#1, p. 375. He had served as a witness to several land transactions before this purchase, however, the earliest being on 10 Sept 1719, according to Chowan Co., NC, Deed Book W\#1, 9. 189.

Unfortunately, this is only a partial account of Thomas's appearance in the records.

A trawl through the North Carolina Historical and Genealogical Register ${ }^{24}$ (looking for all name variants such as Mewboorn, Mewborn, Mewbern, Newboorn, Newborn, Newbern) has produced a more extensive and informative set of records (these, though, are index records created from transcriptions by Hathaway so are limited in content and may not always be correct). 
Vol. 2; p. 285. Henry Bonner to Thos. Newbern: 8ber 16, 1716. Test, Jno. Nairn.

Vol. 1: p. 105. John Yelverton, to Matthew Bryan. Power of Attorney; September 10, 1717. Test, Edward Wingate, Thos. Newborn.

Vol. 2; p. 617. John Nairn to his friend Thos. Rodes. 50 acres North side Morattuck River; Sept. 5, 1721. Test, Thos. Mewborn, Sam'l Williams.

Vol. 2; p. 288. William Smith to Thomas Pierce. 70 acres part of 100 acres known as Poplar Neck, (other part sold to Thomas Newborn) given said Smith by will of his mother, Mary Smith, decd, (on the Sound). Mch 19, 1723-4. Test, Thos. Mewborn, Elizabeth Burwell, Wm. Smith,

Vol. 2; p. 295. William Smith and wife Rachel to Thomas Mewborn. 30 acres part of land known as "Hardy's Old Field," lately in possession of Thos. Pierce, Jr.: Aug. 3. 1723. Test. Sarah Fleder, Thos. Calloway.

Vol. 2; p. 286. Thomas Mewborn to Edmund Gale; Apl. 22, 1724. 100 acres N. E. side Mattacomack Creek, or Queen Anne's Creek joining on lands that were Edw'd Wingate and John Nairn's, where the said Mewborn did lately lived. Test, E. Moseley, Wm Badham.

Vol. 2; p. 446-7. Pagett, Sam'l to Thomas Mewborn. 160 acres on Queen Anne's Creek, and Chowan River Pocosin, May 20, 1729. Test, Thos. Lovick, Rt. Hicks.

Vol. 2; p. 448. Thomas Mewborn to Wm. Badham. 160 Acres on Queen Anne's Creek and Chowan River Pocosin, near Tindal Swamp, bought of Samuel Pagett, March 1, 1729. Test, Jo. Jenure, Kennedy O'Brien.

Vol. 2; p. 452. Thomas Mewborn to Thomas Pierce. Assigns deed for 50 acres purchased March 30, 1732, of Wm. Smith. Nov. 2, 1732. Test Thos. Smith, Cornelius Leary, Wm. Horton.

Importantly, the earliest transaction is in 1716 , less than six years after the arrival of the Palatines. It implies that Thomas was most likely of full age at that time.

Interestingly for those who feel that the spelling of the name has significance, the first record gives Newbern, the second Newborn, the third Mewborn, the fourth Newborn and Mewborn. Eight out of eleven renderings of the name plump for Mewborn. Whether that says anything about Thomas or more about the recorders is a moot point.

Ancestry.com provides some index records also hinting at early evidence. A tax list apparently exists from 1721 (though there is no image or transcription) so Thomas was definitely of full age at that point. ${ }^{25}$ The deed granted in 1722 to Thomas by William Smith is listed, ${ }^{26}$ as is the one from Saml Pagett in 1729. ${ }^{27}$ Thomas, in turn, made grants to William Badham in $1729{ }^{28}$ and Thomas Piesee [Pierce] in $1732 .{ }^{29}$

We also know that Thomas had 100 acres by deed at Queen Anne's Creek in Chowan in $1720 .{ }^{30}$ These timings are significant since Queen Anne's Creek was a prime location in the Chowan/Albemarle area. As today's visitor center has it:

"In 1712, the General Assembly voted to establish a town north of the Albemarle Sound. Town lots were laid out on Queen Anne's Creek and in 1722 the town was named for Governor Charles Eden." ${ }^{31}$

Thomas was investing in prime real estate and was there at the establishment of Edenton (though back in 1710 it was known as Roanoke and had been renamed Queen Anne's Town in 1715). His name, however, does not appear in local histories so we must assume that he focused his energies on the development of his plantation. In any case Edenton was far from a metropolis and the visitor centre and Wikipedia quotes William Byrd saying of it in 1728 :

"They may be 40 or 50 Houses, most of them Small, and built without Expense. A Citizen here is counted extravagant, if he has Ambition enough to aspire to a Brick-chimney. Justice herself is but indifferently Lodged, the Court-House having much the Air of a Common Tobacco-House." ${ }^{32}$

The records so far found give 1716 as the earliest confirmed date for Thomas's presence as a landowner - though the exact place and nature of that first transaction is unclear. That timing also places Thomas as separate from the German and Swiss settlers still trying to establish themselves at New Bern and still struggling with uncertainties over land ownership there. In 1716 Thomas had funds enough to acquire land independently. Importantly too, there are no other Mewborns among these early records suggesting that Thomas arrived on his own.

As a landowner in 1716 it also implies that he was born on or before 1695. We know he was a blacksmith and if he had completed his apprenticeship before joining the Palatines, he might have been about 21 in 1709, placing his birth as 1688, or earlier. That date will be used in this study.

As already suggested, following his transportation to the colony he may have sought, or been pushed into, indentured employment (as a kind of compensation for the expense of the travel). That was typically for a seven-year term, though could be shorter especially for skilled workers. The timing allows, therefore, for arrival in 1710; a period of indenture in which thrift and hard work enabled him to scrape together enough money; then the purchase in late 1716, at about the end of the (perhaps slightly curtailed) indenture period, of a first property. Continuing hard work clearly enabled him to extend his properties, helped by marriage to a property owner (or so we are led to believe in family lore), and to become a relatively prosperous settler. 
His death is certain, to the extent that a will was written, and probate granted, both in 1749, in North Carolina. ${ }^{33}$ In the will, he offered no clues as to his origin. He described himself as a blacksmith, but it is clear that he also had significant land holdings and was a plantation owner in Bertie County. He bequeathed 280 acres and mentioned having distributed other land previously to family members. The will identified his wife as 'Elannar'. Her maiden surname is unknown but family accounts state that Thomas was her second husband, and that she had been previously the wife of John Goreham of Bertie County. Goreham died in 1717 and his will shows that his widow, 'Elenor', inherited his plantation at Queen Anne's Creek. ${ }^{34}$ We know from Thomas's land sale record in 1724 that he had been living on the Creek at that time, so he must have been acquainted with Elenor. What is odd about this is that Queen Anne's Creek is where Edenton was built and is in Chowan County on the other side of the Chowan River from Bertie, where both Goreham and Mewboorn made their wills. Perhaps owning land on both sides of the river was not uncommon (and of course Bertie was separated administratively from Chowan only in 1722).

Documentary evidence for Elenor marrying Thomas Mewboorn is lacking, as is any evidence for her maiden surname (trees online offer Uln, Hayd and Hyde, though without any supporting evidence).

Thomas's will distributed land and property among his living children - six sons and one daughter. We assume there were no others (at least living). Son Thomas appeared to be the principal beneficiary, but it was made clear that Nicholas had already had land settled on him. Nicholas was also to benefit from Thomas junior's portion if Thomas junior were to die. These factors are taken to imply that Nicholas was, in fact, the eldest (and Thomas the second) son. For the purposes of this study the other children are then assumed to have been born in the sequence in which they are first mentioned in the will.

The will has been transcribed as follows (Note, from 1739 Albemarle ceased to be a county. Bertie became a Precinct in 1722 (being divided from Chowan) and became a County in 1739.):

In the name of God Amen, I Thomas Mewboorn of Bertie Precinct, in ye County of Albemarle, in ye province of North Carolina, blacksmith, being sick and weak in body but of Sound and perfect memory thanks to almighty God for same - and calling to mind ye mortality frailty of man and that it is appointed for all men once to Die, I Doe therefore make constitute appoint, and ordain this to be my Last will and testament in manner and form following, First my soul I Recommend in to ye hands of Almighty God that gave it hopeing through the merrits of my blessed Redeemer to Receive a Joyful Resurrection at ye last day, My Body to be buried in Such Christian like manner as to my Execut hereafter named Shall meet and as touching Such [worldly?] Estate as it hath pleased Almighty God to bestow on me in this life I dispose of ye same in manner and form following:

Imprimi's To my Son, Thomas Mewboorn, the plantation containing one hundred acres where I now live lying between John Oaks and John Oxley's land on Flatswamp, which Land I Give to him and his heairs for ever and in case he Die in his minority or without heirs then to fall to my son, Nicholas.

To my Son, Joshua, one hundred acres of Land Joining to the plantation lying down Flatswamp which land I give to him and his heairs for ever.

To my Son, Nicholas, seventy eight acres of Land lying upon broad branch which I give to him and his heairs for ever he having received a sufficient part in land \&c alredy.

To my Son, Moses, my stilyards which I give to him and his heairs for ever.

To my Son, Thomas, ten head of cattle, them and theyr increase which I give to him and his heairs for ever.

To my Daughter, Mary, one Gallon bason which I give to her and her heairs for ever.

To my Son, George, one Dark bay horse branded with two years on the near buttock which I give to him and his heairs for ever.

To my Son, George, the cuppers tules four head of cattle, them and theyr increase which I give to him and his hears for ever.

To my Son, John, one bay mair colt branded with $M$ on the near buttock two head of cattle, them and theyr increase which I give to him and his hears for ever.

To my Son Joshua, one chestnut mair with a blase face brand with TY upon the of buttock and with M on the near buttock two head of cattle them and theyr increase which I give to him and his heairs for ever.

To my Son, Nicholess two head of cattle, them and theyr increase which I give to him and his heairs for ever.

One black horse, one bay mare foals left for the use of plantation.

The Smiths tules for the use of my children and as for my household movables with what Cattell is left I give to my wife and children and after the Decease of my wife to be equally divided amongst my five Sons Thos, George, John, Joshua Nicholess and I Constitute appoint and ordain my true and well beloving wife Elannar Mewboorn, to be Sole Executor of this my Last will and testament

Lastly I Constitute appoint and ordain my true and wellbeloved wife of this my my Last will and testament Utterly revoking and making void all former wills ratifying and confirming this and no other to be my Last will and testament in witness wherof I have here unto set my hand and affixed my seal this Twenty Third Day of February Ano Domine one Thousand Seven hundred and Fourty Nine

Signed Sealed Published honered and Declared In ye sd Thomas Mewboorn to be his Last Will and Testament 


\section{THOMAS MEWBOORN (seal)}

In the presence of us

Edward Rice Thomas Mewboorn

This will, written on the $23^{\text {rd }}$ of February 1749 , achieved probate on the $15^{\text {th }}$ of November $1749 .{ }^{35}$ It provides the start point for further exploration.

There are no records that give birth dates for any of the children (and why Moses is not included is a mystery). However, it is apparent that all, except probably Nicholas, were under age at the time of the will since the principal beneficiary, Thomas, is described as "in his minority" - for legal purposes under 21. From that, to construct a tree, Thomas has been allocated 1729 as a birth year, to make him just under age, and the others have been spaced out at yearly intervals on either side of that. The resulting dates then fit reasonably well with what we know of Thomas's grandchildren. In other words, to when they seem to have appeared and how they are treated in the wills and court records that we have for five of the subsequent lines.

Thomas named his wife as Elannar. Family accounts consistently state that she was the widow of John Goreham before marrying Thomas. Unfortunately, there are no primary source records to confirm that assertion. John Goreham left a will in $1717^{36}$ and his wife Elenor appears in court proceedings in her Goreham name in 1718 and 1719. It is uncertain when she married Thomas (if the family assumption is correct), but the likelihood is that it was later in the 1720 s rather than earlier since the probability is that the children were produced later, so a 1726-27 date is preferred. There is also nothing in the records - no probate or other court papers - to indicate when she may have died. The family tree that emerges from this, for the first three generations is shown in figure 1. In that figure, a w indicates the availability of a will and a $t$ indicates some other testamentary or court papers.

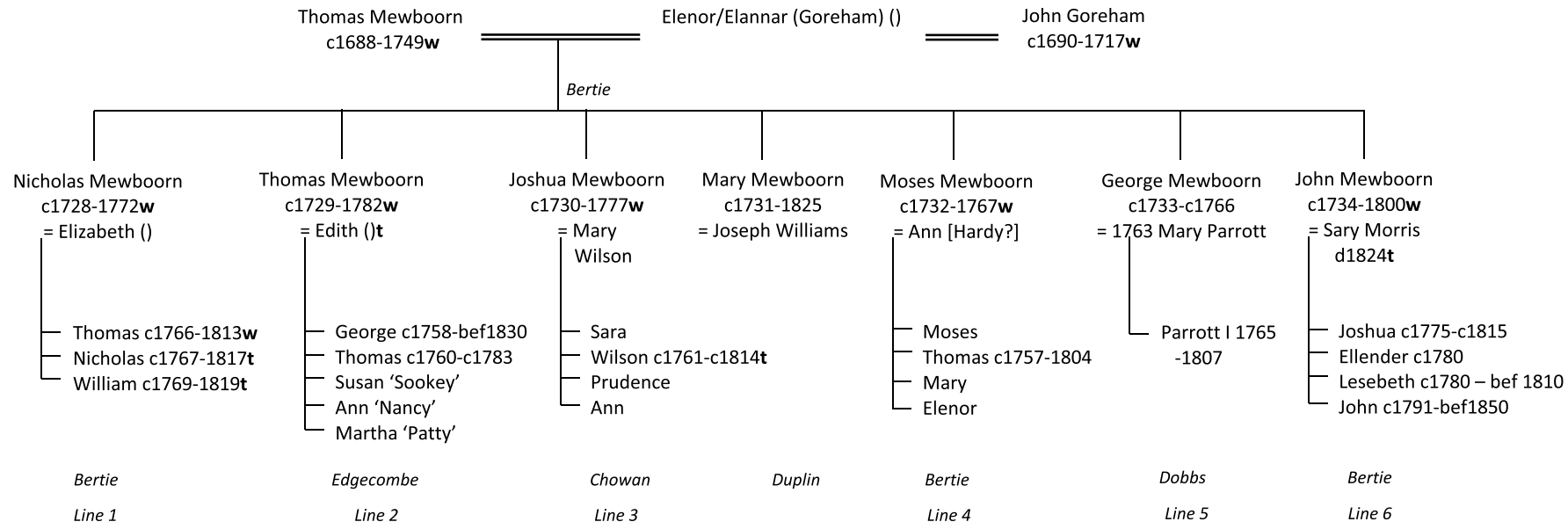

Figure 1. Thomas Mewboorn, his children and grandchildren.

There are aspects of Thomas's life that remain obscure. A close study of land records might help to develop a better understanding of early family movements and inter-relationships. We know that Thomas was at Chowan, on Queen Anne's Creek, until at least 1729 (thus, presumably, in the early days of his marriage to Elenor). However, 20-years later he was at Bertie on the other side of the Chowan River and giving out land at Flatswamp. Flatswamp, in Whites township, can still be found on Google maps, nine miles from Windsor and nineteen across the river to Edenton. It is today still a thinly populated area, wooded along the Flat Swamp Creek and with only occasional patches of open farmland. What occasioned the move from Chowan is unknown as is the date when it took place. We do not know where Nicholas was given his first piece of land or where the second piece at Broad Branch is, but generally speaking he lived and died at Bertie. In turn his eldest son remained at Bertie but the other two lived at Chowan. The second son, Thomas, was given land at Flatswamp but then moved to Edgecombe. Third son Joshua was also given land at Flatswamp but appears to have lived at Chowan, as did his son Wilson. The other three sons were not bequeathed any land. Moses stayed at Bertie, George went to Dobbs and John stayed initially at Bertie but was in South Carolina at the time of his death. All told, three of Thomas's grandsons moved to Chowan but whether that was to live on land originally held by Thomas is not known.

The names of Thomas's children come from his will, while the names of his grandchildren also come largely from wills left by the children. Thomas's children carry English given names. These can all, at a stretch, be rendered fairly closely as equivalent 'germanic' names if they were to be used in the argument over the 'Mewboorn' origin - but it would be a poor argument. Moreover, having a wife who was possibly of English origin, and living in a British colony provides some pressure to fit in. 
Some assurance for some names of descendants (including one son and most of the grandsons) comes from the earliest census records, from 1790 onwards, though before 1850 these records named only the head of the household. Inhabitants were counted by age and gender groupings in these early censuses and the enumerations can sometimes be matched with the full set of names that became available from 1850. There are, though, great uncertainties and difficulties in bridging gaps for the whole century between 1750 and 1850 . Families of Mewborns appear in North Carolina in 1850 whose members cannot be linked back readily to the progenitor, Thomas. However, moving forward from Thomas there are also uncertainties of descent, particularly from Thomas jr and Moses, and possibly even from John so there is a glimmer of hope that some of the emergent families in 1850 are descendants of the first Thomas. DNA studies among present-day name holders might offer additional evidence but, as yet, few Mewborns are known to have tested.

Migration is an important factor in the history of the family. There was official encouragement to move west into less-exploited lands and, for example, at the end of the Revolutionary War in 1783 many men re-settled in Tennessee. Tennessee, of course, had originally been the westernmost part of North Carolina, but with the barrier of the Appalachians dividing the two. A move to Tennessee was clearly not such a stretch for Mewborns in North Carolina and some made that move in the late $18^{\text {th }}$ and early $19^{\text {th }}$ centuries. Subsequently, it was not so difficult for other family members to envisage migration and, in consequence, the family gained confidence and steadily spread out.

\section{Making sense of the early censuses}

The censuses carried out prior to 1850 were enumerations rather than identifications. Only the head of household was named. However, those in the household, though not named, were counted within specified age bands, separately by sex. The patterns can be compared across subsequent censuses to gain a rough idea of the numbers and ages of the various household members (though, over a ten-year gap, the likelihood of deaths and movements out complicates matters and makes conclusions less certain, as does the possibility that not everyone enumerated was necessarily a relative of the head of the household, let alone a child of theirs).

Nevertheless, with caution, the information can be used to develop hypotheses about who people might be related to once they appear as named individuals in their own right in later censuses (e. g. are old enough to appear as heads of their own households) - particularly from 1850 onwards where names and ages, and therefore implied birth years are available.

Throughout this process, though, it must be remembered that the allocation to age bands (or even, later, to specific ages) was not always carried out either carefully or accurately by the householders or the enumerators (indeed, if the householder was not there when the enumerator rode up he might take information from whoever was around, whether properly knowledgeable or not).

In this chapter, the tracking is carried out by householder name, for those names that appear in the earliest censuses. One is a son of Thomas, others may be grandchildren; other names appear suddenly that can only be for younger descendants who have matured enough to establish their own households, and who may previously have existed just as one of the numbered creatures - but from which household?

There is an important cross-over from 1840 to 1850 when for the first time all names are given. Where householders appear in 1850 who had not previously appeared and who claim to have been born in North Carolina then there is a reasonable expectation that they were among those numbered in 1840 (or earlier). Place and age may then serve to point to a possible father. New appearances in 1860 can be examined with similar expectations since they might have been numbered youngsters in 1840 and not yet independent (though they should be identifiable in 1850 living with a householder).

The line of descent is most uncertain between 1800 and 1840 when two generations could have been fitted in after progenitor Thomas's grandchildren. Most of them would have been unnamed in the early censuses, having yet to establish their own household, and some of them may have migrated away from North Carolina following government encouragement to head out West. We can identify possible sons and broadly when they may have been born - but linking them to named people in new locations from 1850 onwards is a much chancier business (those from a generation following a migration will not even have been born in North Carolina).

Of the six lines from progenitor Thomas:

1. Nicholas's descendants are largely traceable, despite their migrations. They are mostly known as Newbern.

2. Thomas's descendants create some problems. Those from his younger son Thomas via grandson Archibald are well established, but those from his grandsons via eldest son George are much more doubtful. There are candidates to link back to, but exact parentage is less certain in the absence of hard records. Two layers of hypothesis have been constructed leading to a possible descent from George (in some cases leading to the Newberns still living at Currituck). However, there is no certainty that the right conclusions have been reached and researchers with better access to local records may find evidence that leads to different conclusions. 
3. Joshua's descendants via great-grandson Charlton Augustus are well established.

4. Descent from Moses is problematic. It seems possible it may have occurred via his son Thomas, and a grandson, Thomas (probably the son of Thomas), but is dependent on some unproven supposition.

5. George is believed to have had just one son, Parrott, from whom a well-studied descent at Falling Creek and Tyson's Marsh is known and has good support from published family bibles and research within the family.

6. Finally, with John, we have a clear line from his younger son John and grandson Eli. Descent from the eldest son, Joshua, is more uncertain though a line from grandson William seems possible. However, descent relies on an assumption that records from Kershaw in South Carolina relate to this John. If that assumption is wrong, then the hypothesis fails.

There are issues, therefore, in three of the lines -2 . Thomas, 4. Moses, and 6. John.

We have some good records in the form of wills and court records in the earlier days and we have good records from 1850 onwards through the censuses. The days of the early Federal censuses, 1790-1840, where only the householder is named, represent a crepuscular period where tantalising glimpses of possible links can be theorised about. However, to make sense of the early census structures names have to be assigned to numbers and that is fraught with difficulties and is often dependent on assumptions based on uncertain premises.

To gain some insight, census entries for all the early censuses have been tabulated in a spreadsheet. Conformity between census periods can be checked and they can be used to search for candidates who may have migrated away from the point of origin. This does not offer certainty in matching since ages suggested to the enumerator were often based on guesswork (the parents typically had no birth records at this time) and is made more difficult by the same names being used in different families (lots of Johns, for example).

The example in table 1 illustrates the difficulty of working with this material (the shaded sections represent the age bands used in the censuses - in practice, using differently coloured bands is more effective than shades of gray). Note that slave owning is characteristic of the Nicholas line and helps to provide assurance that we are looking at the right people.

Table 1. Example of births tabulated by age bands from early censuses.

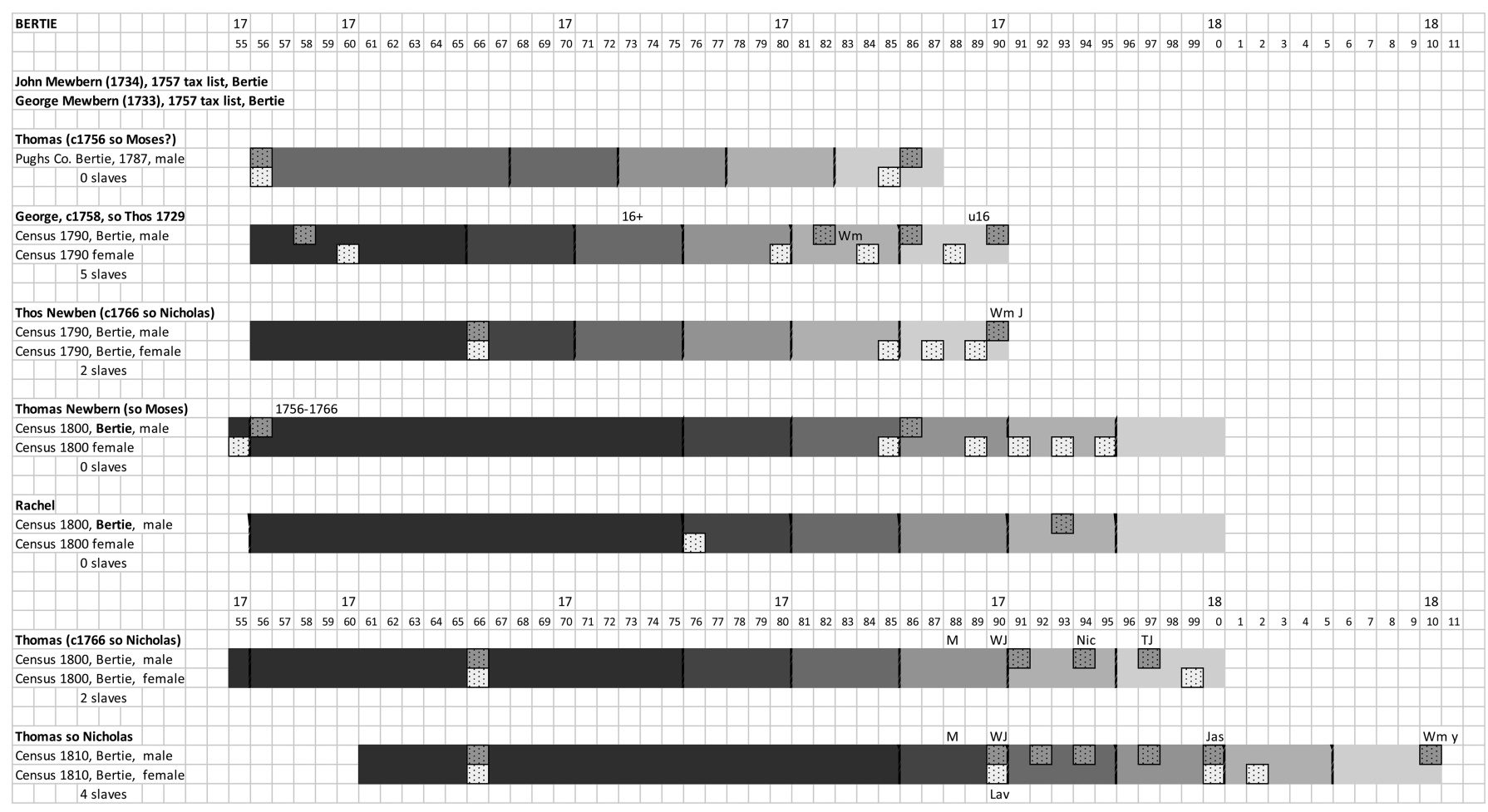


Mysteries remain. There are three records for previously unknown female householders at Bertie - Rachel in 1800, Eliza in 1810 and Elizabeth in 1830. As householders, the likelihood is they are widows, or an adult only-child whose parents have both died. The question is What family is each from?

- Rachel's age in 1800 is between 16 and 25, so born between 1775 and 1784 , and she is with a male under ten (and no slaves).

- Eliza in 1810 is 45 and over, so from 1765 or earlier, and is with one male 16-25 and one female 16-25, and no slaves.

- Elizabeth in 1830 is aged 70-79, i.e. born 1751-1760, and was living with two females - one 5-9 and the other 15-19.

Eliza and Elizabeth could be the same person, though the absence of a record in 1820 is a concern. None is clearly identified and fitted to known family structures.

Based on all the records and on the analysis of censuses, the six lines descending from Thomas Mewboorn have been defined in the chapters that follow.

Note that a coding system is used in Section titles to help orient the reader.

At the top level L1, L2, L3 etc. identifies one of the six lines of descent - actually the second generation.

L1.1, L1.2, L1.3 etc. identifies the first, second and subsequent sons in a line - major headings and the third generation. L1.1.1.1, L1.1.1.2, L1.1.1.3 does the same for the fifth generation and the next set of sub-headings.

G indicates a generation, and the material and trees are generally presented in blocks of three generations: G1-G3, G3-G5 and G5-G7. The trees therefore overlap by one generation to help the reader follow the overall structure and pattern of descent.

This coding is not inherently important but simply acts as a means to structure the material in this work and to orient the reader. Even with just seven generations there are lots of people (and lots of shared given names) and it is not always easy to keep track of where you are.

\section{LINE 1 - from Nicholas Mewboorn, c1728}

Nicholas Mewboorn lived at Bertie. Evidence from his father's will has been interpreted as showing that he was the eldest son of Thomas Mewboorn and his birth is suggested to have been around 1728. Nicholas died prior to any censuses but he does appear in the 1768 Bertie County Tax List (with one slave) ${ }^{37}$ thus further confirming his presence and location.

We know details of his family from his will. The will was written in 1772 , though he did not die until some point in $1774 .^{38}$ The will tells us that his wife was Elizabeth, though her maiden name is not known and there is no trace of a marriage record.

We do know from probate records and later marriage records that Elizabeth married twice more after Nicholas's death. ${ }^{39}$, 40 Mrs John Bennett Boddie gives Sparter as a maiden name for Elizabeth but offers no source evidence for this; indeed, it may even have arisen through confusion from his son Thomas's marriage to an Elizabeth Sparkman (which Boddie gives as Elizabeth Jones, despite there being a record for the Sparkman marriage).

The main part of Nicholas's 1774 will has been transcribed as follows:

"... I Nicholas Mewboorn of North Carolina in the County of Bertie ...

Item. I give \& bequeath to my to my [sic] Dear \& Loving wife Elizabeth all my Stock of Horses Cattle Hogs \& sheep \&c \& all my other Moveables of what kind or nature [?] (Negroes Excepted) all which I give to her During her natural Life or Widowhood and after her Marriage or Decease to be equally Divided between all my Children

Item. I give and bequeath all my Land to be Equally Divided between all my Sons - the Plantation with his an equal Part to my old son Thomas

Item. As to my Negroes the Negro woman Lyd I desire she should be sold \& my Debts to be paid with the money as far as it will go and the Negro man Joe I Desire should be Hired out yearly to the Highest Bidder till my oldest son Thomas comes to the age of Twenty one years and at the Expiration of that term of time his hire to be for my wife to help to raise my Children

Item I give \& bequeath the abovesaid Negro man Joe to be Equally divided among all my children at the Expiration of the above Term of time to wit my son Thomas's Minority my son Thomas to have the sd Negroes \& Pay the last of my Children \& Equal Dividend of his the sd Negroes value

Item I give \& leave to my Dear \& Loving Wife the one third Part of sd Land \& Plantation During her Natural life and the use of the other two thirds till my son Thomas is twenty one years of age 
Item I [?] Constitute \& ordain my Brother Thomas Mewboorn \& my friend William Hardy Executors of this my Last will \& testament \& trustees for my wife \& children ... In Witness whereof I do hereunto set my hand and seal this 24 th day of September in the year of our Lord $1772 . . . "$.

Note the use of the Mewboorn spelling.

The will identifies only wife Elizabeth and the eldest son Thomas. The other sons, Nicholas and William, are known, however, from their appearance in subsequent court papers relating to the settlement of the estate, particularly the apportionment of slaves. These records give names for the people who have inherited so there is no doubt about sons Nicholas and William. The will makes clear that all children are under age, therefore born after about 1751. The court papers are interpreted as implying births in the latter part of the 1760s, and birth dates have been estimated and applied accordingly.

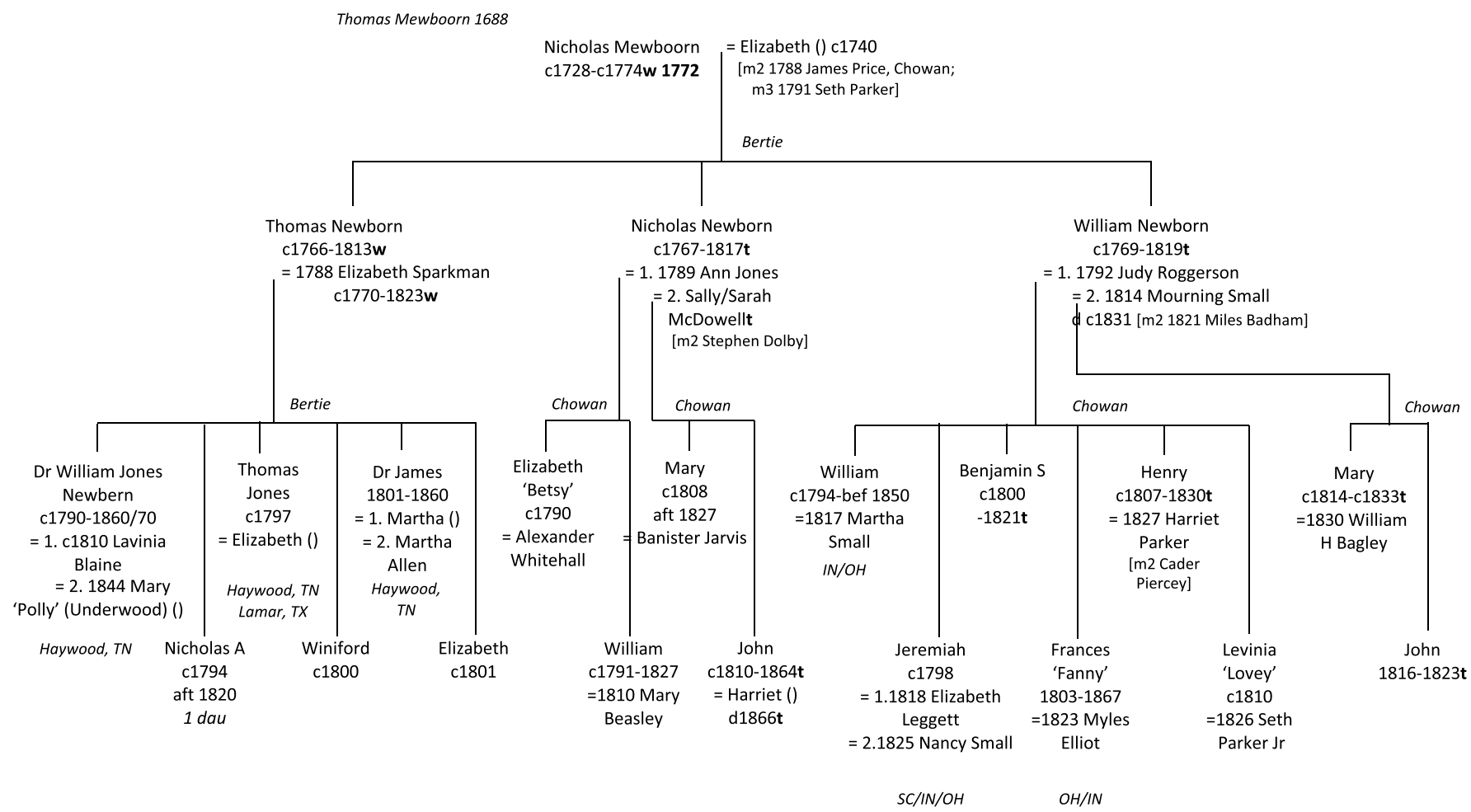

Figure 2. Descent from Nicholas Mewboorn, generations 2-4.

Descent can be traced from all three sons. Thomas and his descendants remained in Bertie while Nicholas and William settled in Chowan. Marriage records provide good evidence for their wives, other than for Nicholas Jr.'s second wife, Sally, known only from probate records (which include the fact that she, in turn, was married again to Stephen Dolby, who had acted as guardian to some of the children). She was left land in the will of her father, Stephen McDowell, in which she is named Sarah Newbern, confirming the link. ${ }^{41}$

Son Thomas left a will, as did his wife, Elizabeth Sparkman. There are no wills for Nicholas and William but there are various records relating to guardianship of under-age children and again to the apportionment of slaves. A significant number of names from the fourth generation is known, therefore. However, that is not to say we have them all.

\section{Thomas 1766, L1.1: G3-G5 - Bertie, NC to Tennessee}

Thomas was the eldest son of Nicholas. He is believed to appear, though unnamed, in the censuses for 1790,1800 and 1810 at Bertie and the bands for age suggest that his birth year was probably about 1766. He preferred the Newborn spelling, while his children favoured Newbern. There is a record of his marriage to Elizabeth Sparkman in 1788. From that date, and from mentions in wills, and in censuses it has been possible for estimates of the birth years of the children to be made (though no records have been found giving specific dates for any of them). The children continued to live and start families at Bertie for some time until William Jones, the eldest, moved first to Knox, then to Haywood, Tennessee. He was followed before 1840 by Thomas Jones and James. The sons appear in early censuses in their own right and, in turn, some of their sons can be found in the 1850 census. However, a good number of male household members remain unaccounted for and may represent opportunities for future researchers to expand the family, if new records can be found. 
We have a will for Thomas, the main part of which has been transcribed as:

"...I Thomas Newbourn... nineteenth day of July... one thousand eighteen hundred and thirteen

First I lend to my well beloved wife Elizabeth, negro man James \& negro woman Sarah, her natural life or widowhood, I also lend my wife Elizabeth one of either bed \& furniture, \& one mare named Punches, her natural Life or widowhood, and after her marriage or Death all of the above mentioned propertys to be sold and Equally Divided between all my children. I also lend to my wife Elizabeth, my plantation whereon I now live together with two hundred \& fifty Acres of land, adjoining said plantation \& [Mizells; line added in] her natural life or widowhood \& after her marriage or Death, I give and bequeath the above mentioned Two hundred \& fifty Acres of land to my son James Newborn, to him and his heirs for Ever. I give and bequeath to my son Wm Jones Newborn, Two hundred \& fifty Acres of land, adjoining my son Jameses land beginning on at Cuekelmaker Swamp, and Running out to the back line, to bull branch, to him and his heirs forever. I Give \& bequeath to my son Thomas Jones Newborn Two hundred \& fifty Acres of land, adjoining my Son Williams land, so as to Inclose the Rollins place and the moruel Islands and the Ded woods along the little ditch in bull branch and out so as to get the number of acres to him and his heirs forever. I also Give and bequeath to my Son Nicholas Newborn Two hundred \& fifty Acres of land biging [sic] at my Son Thomases line on the Run of Cucololmaker Swamp then up the [?] Cases of the Run of Said Swamp to Reuben Harrisons line and along said line so far as to Include Two hundred \& fifty Acres of land to Join Thomases land to him and his heirs forever. I will that all the Rest of my out Lands be sold at one two \& three years [Concoldits?] \& the Money arising from the Sales of said lands to be equally divided between my Two Duaghters Elizabeth \& Winifred. I will that my negro man andreye \& all the Rest of my property be sold. I will that my Son Nicholas have three months Schooling \& my son Thomas have six months Schooling \& my Son James have Eighteen months Schooling \& my Two Daughters to have each Twelve months Schooling, the Schooling of all the above mentioned Children, to be paid out of the monies arising from the Sales of my property. Then I will that all my Just Debts be paid, and the overpluch of the moneys, if any, to be Equally divided among all my Children. Lastly, I will that my Children all live with my wife, and I hereby make and ordain my worthy friend Charles Sowell \& my son Wm Jones Newborn Executors of this my last will and testament" etc.

Note that Thomas is called Newbourn in the will, a fairly uncommon spelling variant, while his sons are rendered as Newborn. Wife Elizabeth and all six children are named, confirming that aspect of descent. All children bar William Jones were to receive schooling, suggesting they were still under age (i.e. born after 1892). That corresponds reasonably with census information. Incidentally, the later inventory of Thomas's effects showed he was a cooper, as well as a farmer, with the makings of nearly 200 barrels in his stock.

Subsequent to Thomas's death we might have expected a census entry for Elizabeth in 1820 as the householder on Thomas's place, but that has not been found (neither is she with sons William or Nicholas). However, we do have a will for Elizabeth in 1823. The principal part of that has been transcribed as:

State of North Carolina Bertie County

In the name of god amen. I Elizabeth Newborn...

As touching such worldly goods as it hath pleased god to Bless me with I give and despose of the same in the like manner and form following first I give and bequeath to my Son James Newborn And my daughter Elizabeth Newborn

and also my Daughter winiford Newborn and I also give my Son James Newborn my oldest horse \& also to my daughter Elizabeth Newborn and Winiford Newborn one yoke of oxen \& also to my son James Newborn I give one bed \& also to my daughter Elizabeth Newborn one bed \& also to my daughter winiford Newborn I give one bed

and all my cattle and hogs to be Devided between my son James Newborn and Elizabeth Newborn and to my daughter winiford Newborn

\& also all my Sheep to be sold and the money devided between my son James Newborn And Elizabeth Newborn and winiford Newborn

And also all the rest of my property to be sold and other Money divided Equaly devided between the them three and besides a enough to pay my debts out of my estate

\& also to my daughter winiford I give an Chist \& also to my daughter Elizabeth Newborn one loom And I also give my son William J Newborn five shillings Sterling \& also to my son Nicholas A Newborn five Shillings Sterling \& also to my son Thomas J Newborn Five Shillings Sterling ...

Set my hand and seal this $27^{\text {th }}$ day September in the year of our Lord $1823 \ldots$

NB desire for my Son James Newborn to be executor...

Proved November term 1823

Elizabeth's will is firmly wedded to the Newborn spelling and is focused on James and her two daughters, perhaps indicating that they were all still living together (while the three older sons were by then independent). The absence of James as a householder in the 1820 census is further evidence that he was still under age at that point. Figure 3 shows the tree assembled from wills and census information. 
Thomas Mewboorn 1688

Nicholas Mewboorn 1728

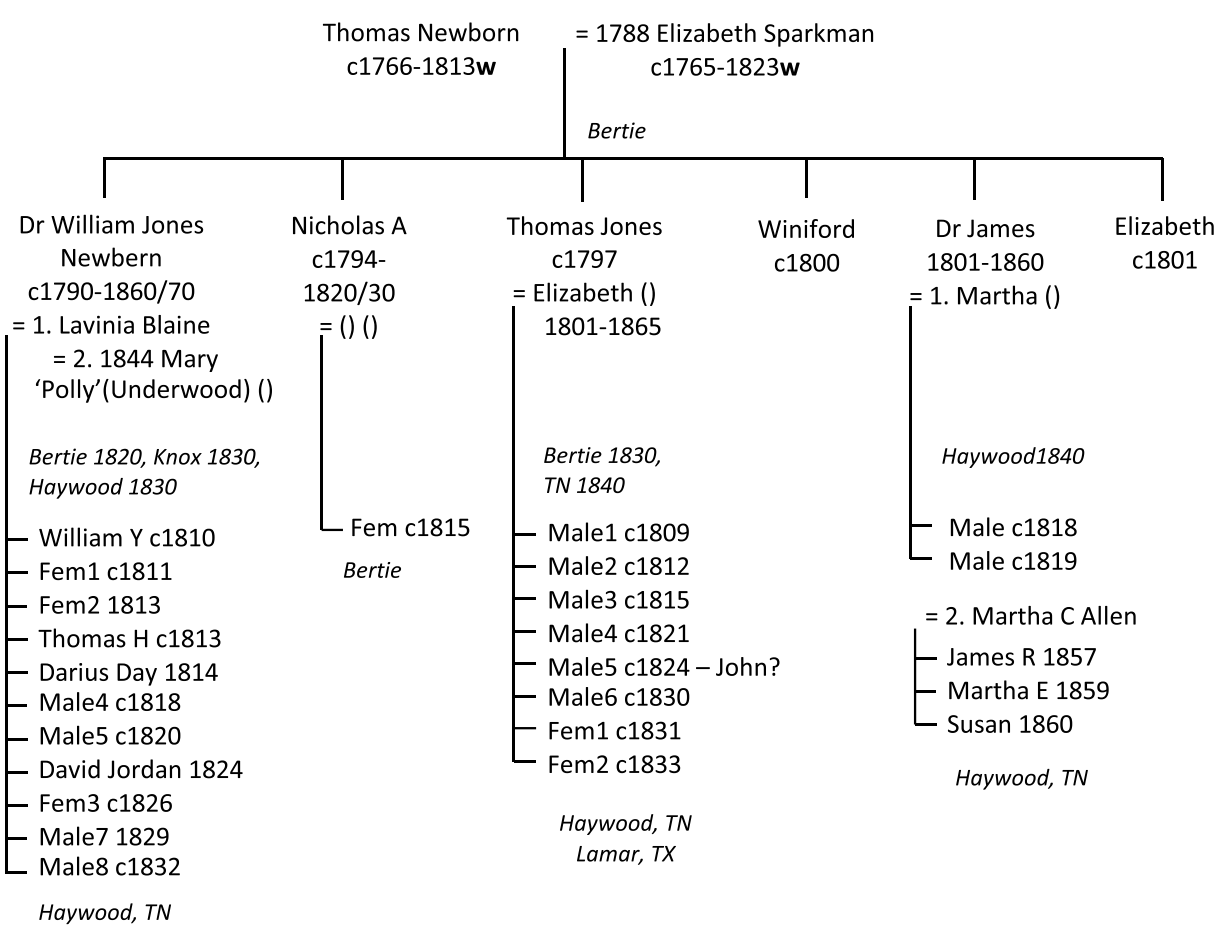

Figure 3. Descent from Thomas Newborn, c1766, generations 3-5.

Two of Thomas's children became medical practitioners, arguably an increase in status from the farming, and an indication that the 18 months schooling bequeathed to James by his father was a sound investment.

William Jones's descent can be established clearly. Early censuses indicate that both Thomas Jones and James had young males, possibly sons, living with them but what their names might have been is uncertain. Thomas Jones moved later to Lamar, Texas so significant migration is a feature of this line.

Dr William Jones was still at Bertie in 1815 when he appeared in the tax list for William Sparkman's District. He had 285 acres with a $\$ 570$ valuation; 1 White Poll and 2 Black Polls. ${ }^{42}$ He was still at Bertie in 1820, but by 1830 had moved west to Tennessee - carved out of the original North Carolina - first to Knox then to Haywood where he was last seen in the 1860 census. The numerations would allow for William $\mathrm{J}$ and his wife Lavinia Bains to have had as many as 8 sons and 3 daughters. However, records provide links to only four named sons. Some online trees claim that a George Washington Newbern, born about 1830 and who lived at Hardeman, was a son, but since he consistently claimed to have been born in Virginia, and that his parents were born in Virginia that seems unlikely. Even William's second marriage in 1844 to Polly Underwood took place at Gibson, Tennessee.

The other children were under age at the time of Thomas's death and appear in court papers.

Nicholas A has Charles Sowell appointed guardian on the $10^{\text {th }}$ of November 1813 , but by 1820 he appeared as a householder with a female of around his own age and another female under ten - potentially a wife and daughter. However, that was the last that has been found of him.

Thomas Jones also had Charles Sowell initially appointed as his guardian, but his brother William Jones took over in 1817 (helping to make a plausible estimate of his brother's birth year). He appears at Bertie in the 1830 census where male household members (one under 5 , one between 5 and 9, two between 15 and 19, one between 20 and 29) represent potential for descent. There may be some doubt as to whether the three oldest were sons of Thomas J. Might they have been orphans of the vanished Nicholas A?

Thomas Jones is named in a tax list for Haywood, TN in 1837 with a 300-acre holding. The 1840 census shows him with a possible wife and as many as 7 children - 5 males and 2 females - about five of whom were probably born at Bertie before the move to Haywood. What happened 
next is quite uncertain. A Thomas $\mathrm{J}$ of about the right age and born in North Carolina, appeared in the 1850 census at Lamar, Texas, but on his own, though another household at Lamar at the same time for a John Newbern may well be a son (given that the name is relatively rare). Another son might be the Thomas $\mathrm{J}$ who is listed in the Confederate Army for the $9^{\text {th }}$ Battalion Georgia Artillery. The youngest son born around 1830 would be a good candidate for him, though what became of him subsequently is unknown. There is, however, a memorial entry on findagrave.com for a Thomas J Newbern at Paducah, Kentucky, but with no dates.

An entry for John of about 1824 is given later but the line appears to have ended soon after.

Dr James was a farmer and physician at Haywood, TN where he died in 1860 . There is a lack of clarity over his matrimonial state. The 1840 census shows him at Haywood with a household consisting of a female aged 30-39 (similar to his own age) and two males aged 20-29 who could have been sons. In 1850 he appeared with a wife, Martha, aged 45 and no children. That Martha matches the 1840 profile, while the 'sons' of 1840 would by then have been independent, though who they were and where they might have been living has not been established. James died early in 1860 and is buried in the Allen family cemetery at Brownville, Haywood. There is a census entry later that year at Haywood for a Martha C Newbern aged 26 (so, much younger than the first Martha) with a two-year old James and a one-year-old Martha. Also living with her was Charles Allen, a medical student. In 1866 Martha married Clinton Trotman then appeared with him in the 1870 census with young James Newbern and a ten-year old Susan Newbern (but no Martha) suggesting that Martha was pregnant at the time of Dr James's death. By 1880 Clinton was a widower. This is interpreted as James having been married twice, each time to a Martha, though no marriage records have been found. The second marriage may have been around 1856 to Martha Allen. Her maiden name is confirmed later in the death record for one of her Trotman sons (so the Charles Allen living with her in 1860 may have been a brother) and explains why James was buried in the Allen family cemetery.

The fate of Thomas's daughters, Winifred and Elizabeth has not been resolved.

William Y 1810, L1.1.1.1: G5-G6 - Madison, TN

William $Y$ Newbern was the first son to William Jones. What the $Y$ stood for has not been discovered. He settled at Madison, Tennessee and his family from four marriages is shown in figure 4 .

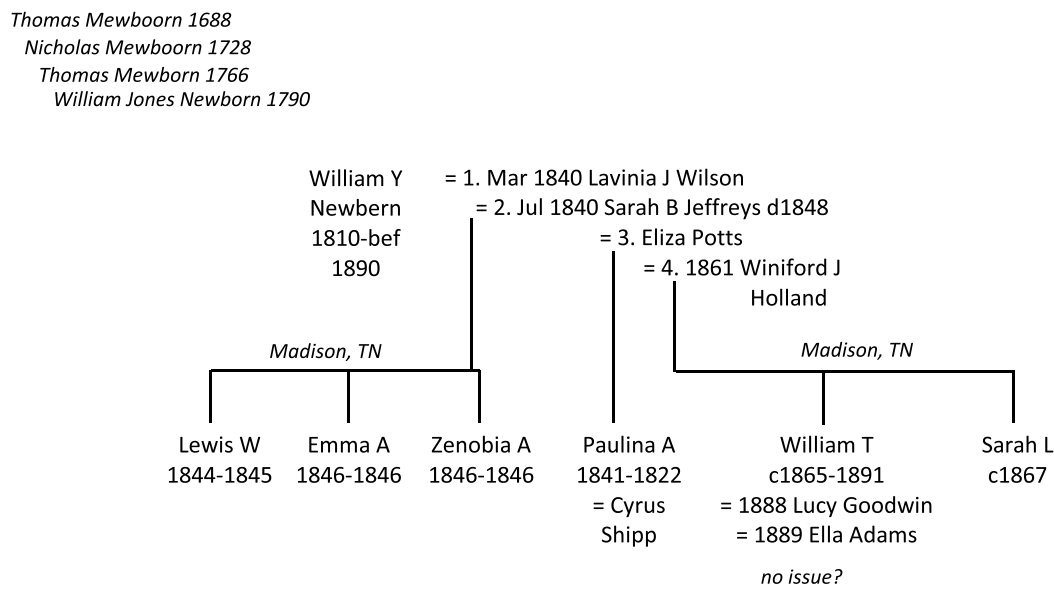

Figure 4. Descent from William Y Newbern, 1810, generations 5-6.

William $\mathrm{Y}$ is in all the censuses at Madison, TN between 1850 and 1880 and presumably died between 1880 and 1890, though no record of death or burial has been found. He married four times and there are records for three. The first marriage, to Lavinia Wilson, was brief and apparently childless and four months later, still in 1840, he married Sarah Jeffreys by whom he had three known children, though the first was not until 1844 and all died as infants. The third relationship, with Eliza Potts, is not blessed with any record of marriage. She does, however, appear with William in the 1850 and 1860 censuses as his wife. These censuses also record a daughter, Paulina, apparently born in 1841 after the first two marriages - but during the time of the second and before any of the daughters from the second. This is a curiously complicated situation and others may want to ask whether the records can be interpreted differently.

William had a son, William T in 1865, by fourth wife Winiford Holland, but he, despite marrying twice in the late 1880s, seems to have had no issue so this line ends there. 
Thomas Howe 1813, L1.1.1.2: G5-G7 - Madison, TN

William Jones' sons were a capable bunch and inclined towards medicine. Thomas Howe Newbern was a doctor as was his eldest son William Wilson. They lived at Madison, Tennessee where Thomas appeared in the censuses for 1860 and 1870.

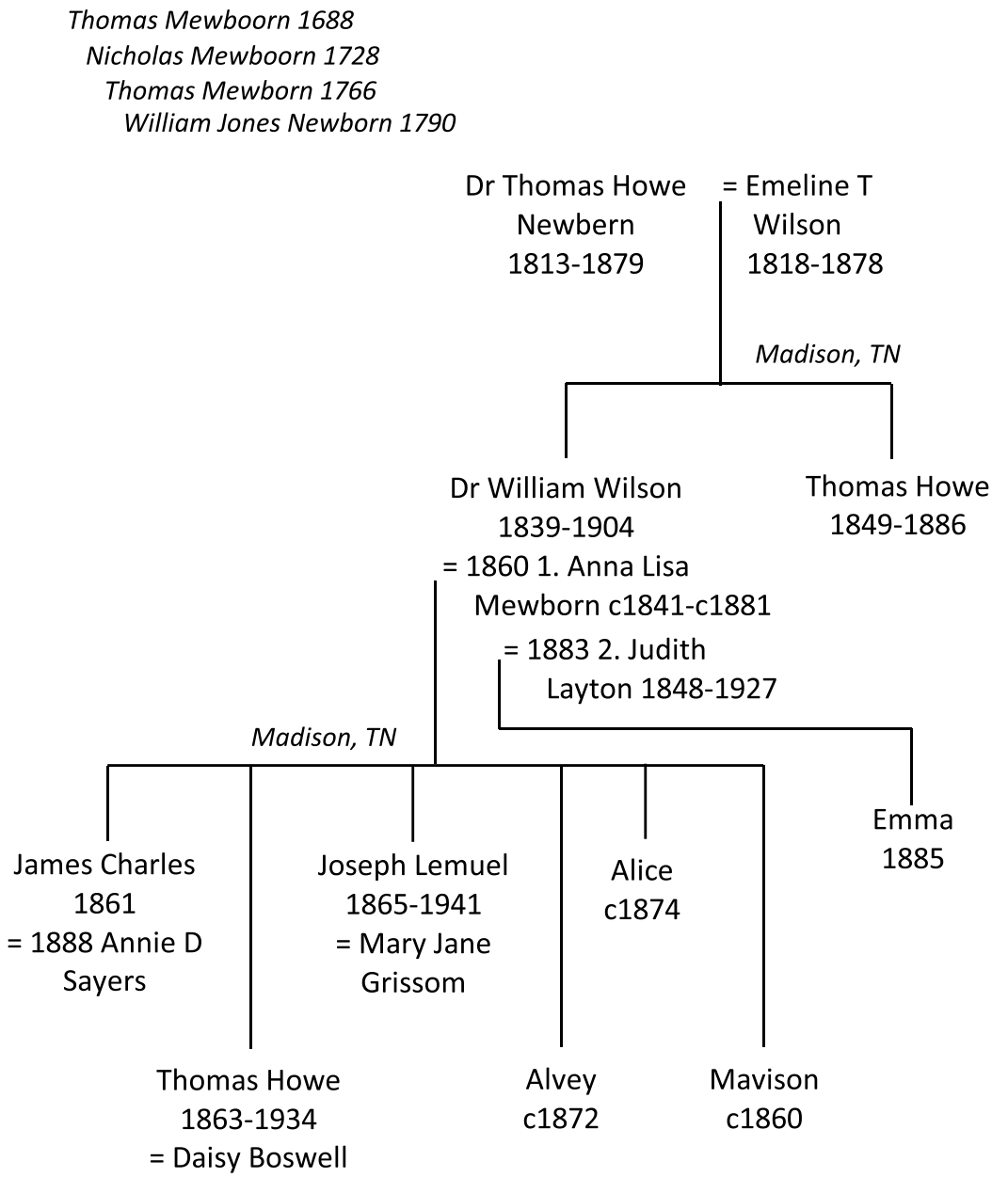

Figure 5. Descent from Thomas Howe Newbern, 1813, generations 5-7.

This family was also engaged in military matters. A Thomas $\mathrm{H}$ Newbern is known to have served in the Revolutionary War of $1861-65^{43}$ though which, if either, of the T.H.s he might have been has not been established. T.H. senior would have been quite old to have been serving while T.H. junior would have been young.

William Wilson Newbern also served as a Major in the Confederate army between 1862 and $1865 .^{44}$

As a footnote, we can see intermarriage between different family strands. Anna Lisa Mewborn, the first wife of Dr William Wilson Newbern, was a daughter of Charlton Augustus of line 3 from Joshua. Both were of the sixth generation. Anna died aged just 39 and two years later, in 1883 , William married Judith Layton. By 1900 he had moved to Memphis with her. His progeny lived on into the $20^{\text {th }}$ century and may have present day descendants.

Thomas Howe Jr (1849-1886) continued in the professional ranks, becoming a lawyer. He was living with his brother, William at the 1880 census. He never married.

Darius Day 1814, L1.1.1.3: G5-G6 - Madison, TN

Darius Day was another doctor and lived and practised in Madison, Tennessee. He was married, at 35, to Elizabeth Hill. They had two children before she died in 1854 aged just 25. A year later Darius died at 40. 


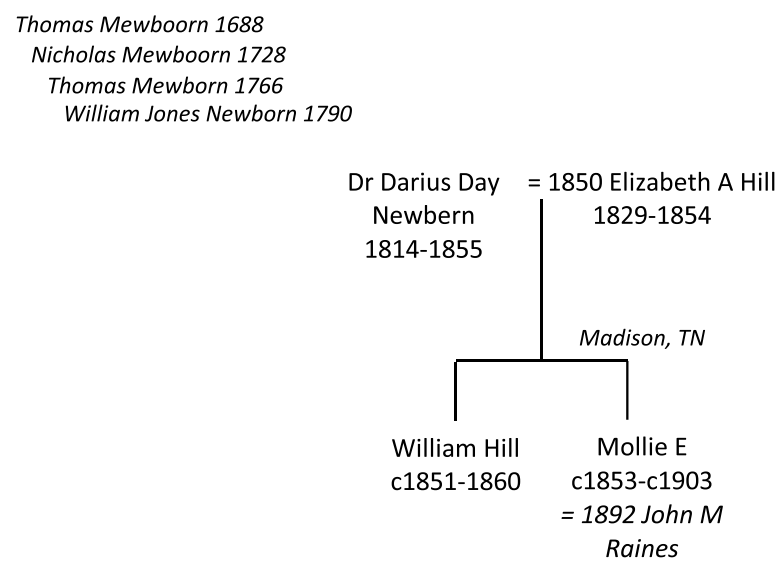

Figure 6. Descent from Darius Day Newbern, 1814, generations 5-6.

Darius and Elizabeth's son William died young and this line went no further. There is some doubt as to whether Mollie did marry John Raines and did die in 1903. The marriage record specifies a Mollie Newton and in the 1900 census she is listed as aged 31, i.e. born about 1869, much too late. The Raines claim comes from notes added to a findagrave burial record and must be doubted.

David Jordan 1824, L1.1.1.4: G5-G7 - Tennessee to Arkansas

David was the seventh child of William J and was born at Bertie. He too became a physician and by 1850 was living with brother Darius at Madison. Later that year he married Kitty Ramsey and had eleven children by her. In 1870 and 1880 they were at Hardeman, Tennessee, living in Bolivar. In 1870 he professed to being a merchant, but by 1880 was back to preferring to being known as a physician. He is buried at the Union Cemetery in Bolivar.

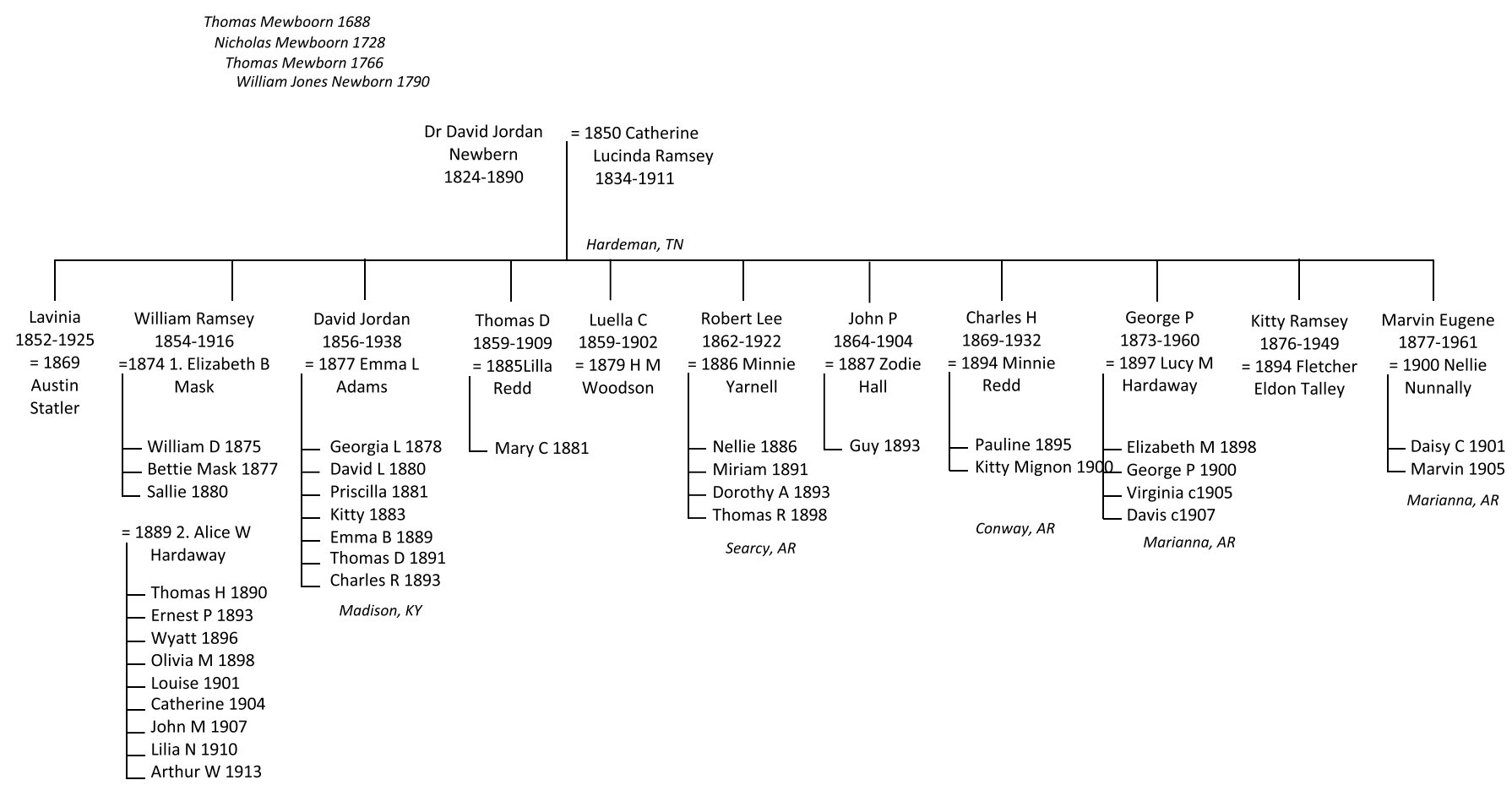

Lee, $A R$

Figure 7. Descent from David Jordan Newbern, 1824, generations 5-7. 
Of Dr David's eight sons:

- William Ramsey farmed at Hardeman, until around 1891-92 when he moved with his second wife to Mariana in Lee County, Arkansas. He moved again around 1910 to Donaghy Avenue, Conway, Faulkner, where he was living on his own means, perhaps retired at 55. William had several sons to carry on the line.

- David Jordan Jr. had a varied life as a merchant, labourer, drummer at a flour mill, and gardener. From 1880 to 1910 he was at Hustonville, Lincoln, Kentucky but by 1930 he was at Pulaski. He was buried back at Hustonville in 1938. David had three sons to carry on the line.

- Thomas D. worked as an agent in the fruit trade at Hardeman and appears there in censuses from 1870 to 1900 . Only one daughter is known from his marriage to Lilla Redd.

- Robert Lee, after farming, became a travelling salesman, living with wife Minnie Yarnell at Searcy, Arkansas. His only son died at 21.

- John P. was a nursery agent. He moved to Trenton in Gibson County where he married Zodie Hall. They had one son.

- Charles Henry was variously the proprietor of a general store and a travelling salesman. He was raised at Bolivar but after his marriage in 1894 to Minnie Redd, lived at Conway in Faulkner County where he appeared in censuses from 1900 to 1930 , and where he was buried in 1932. No sons are known.

- George Pierce was a dry goods merchant. He lived for a while in Memphis with wife Lucy but settled at Marianna in Lee County. He had two sons to continue the line.

- Marvin Eugene was a wholesale grocer. He lived for a while at Independence; was lodging at Newport in 1910 ; then in 1920 and 1930 was with wife Nell at Marianna where he died in 1961 and was buried at Cedar Heights. They had one son.

There are some fourteen sons in the seventh generation, several born in the twentieth century, so descendants of Dr David Jordan may well be with us today.

John 1824, L1.1.3.1: G5-G7 - Lamar, TX

John is taken to be one of the un-named sons of Thomas Jones who appeared in the 1830 census at Bertie and 1840 at Haywood, Tennessee. This relationship is assumed because he appears along with an older Thomas J, though in separate households, in the census at Lamar, Texas in 1850. John was registered as being 26 and having been born in North Carolina. That information can be equated, as a working hypothesis, as pointing to the fifth son of Thomas J, born at Bertie. Fifth son, of course, really means fifth numbered young male from the 1830 and 1840 censuses.

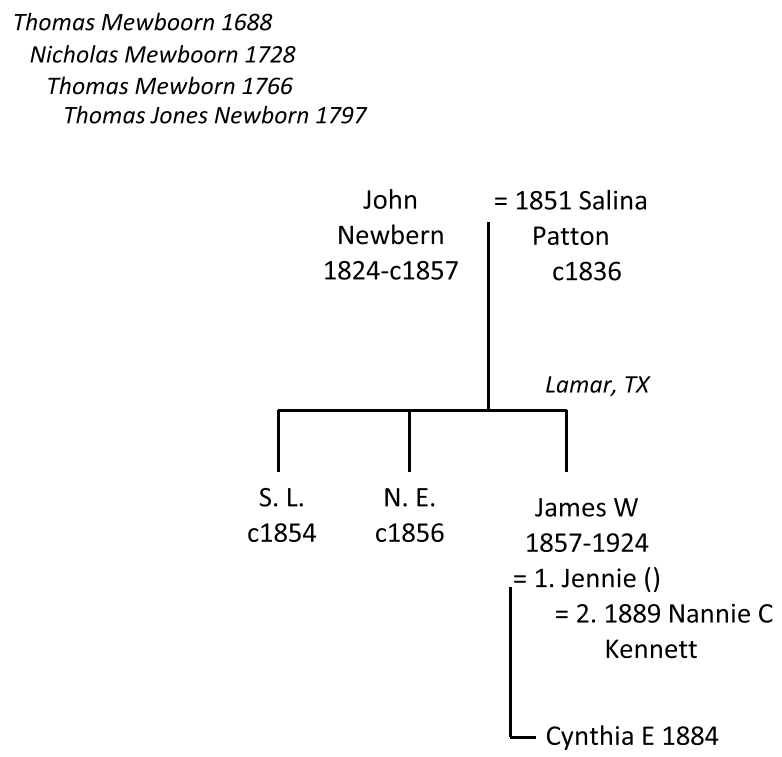

Figure 8. Descent from John Newbern, 1824, generations 5-7.

John's son James is known to have been born in April 1857 and since his mother, Salina, married Lewis Harmon in June 1859 we can be reasonably sure that John died between 1856 and 1858. Salina still had her three Newbern children with her in the 1860 census, but the two girls have not been found subsequently. James can be found farming at Lamar through the censuses until 1910. He had no sons, so the line ended there. 
James R 1857, L1.1.4.1: G5-G7 - Haywood, TN

James was the only son of James (1801) and Martha Allen. He was born on the $11^{\text {th }}$ of December 1857 at Haywood, Tennessee. He farmed there, married Anna Bond in 1878 and appeared in censuses from 1860 through to 1940 before dying and being buried at Oakwood Cemetery, Brownville.

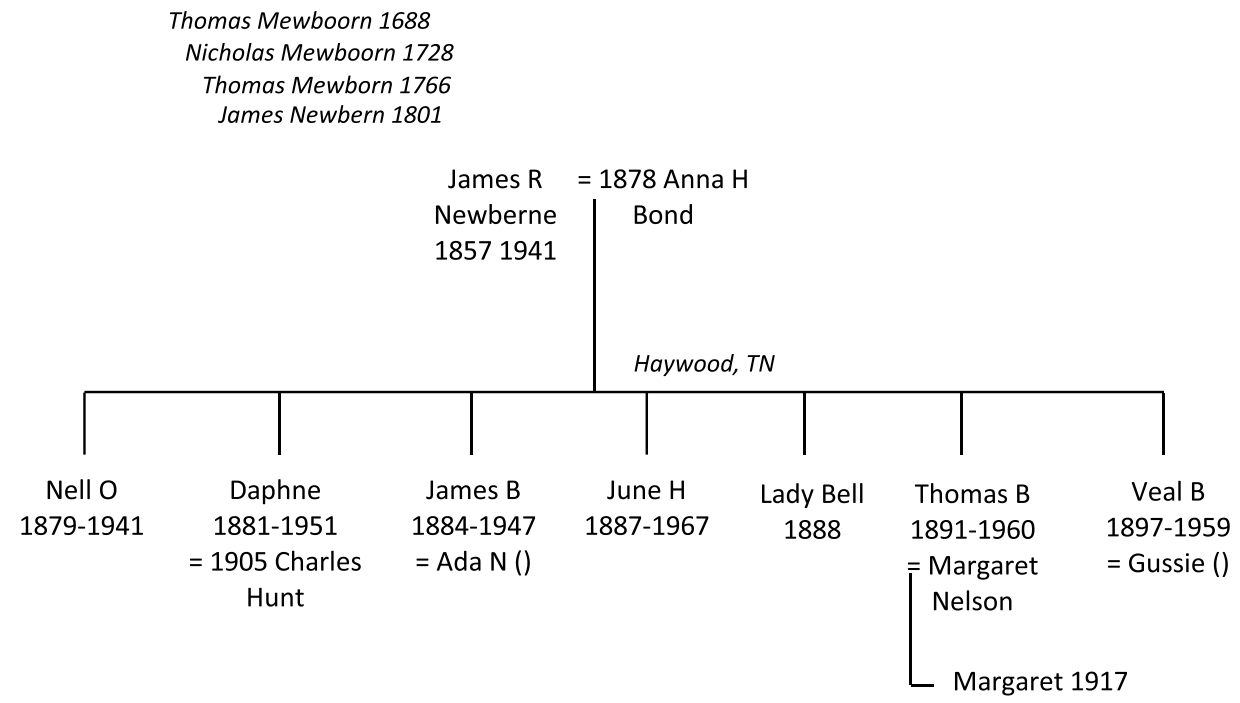

Figure 9. Descent from James R Newberne, 1857, generations 5-7.

There were four sons, but the line does not seem to have continued from any of them:

- James Bond appeared at Long Beach California in 1924 and 1925 as a salesman for the Fitzgerald Music Company and was registered with wife Ada, though no marriage record has been found. He was with Humphreys Music in 1928 but living alone at the YMCA, and by 1932 was registered as a voter in Los Angeles where he died in 1947. No evidence of issue has been found.

- Second son June H. farmed at Haywood, remained single, and is buried at Brownsville.

- Thomas Bond was manager of a piano store at Huntington, West Virginia in 1920 then became a piano salesman in Atlanta. He eventually moved to Decatur, Georgia where he was buried in 1960, having died in Birmingham, Alabama.

- Veal Bond was a travelling salesman. In 1928 he was in Tulsa and appeared there in the 1930 census. By the 1940 census was at the Shreveport YMCA as a single man. However, the city directory of 1940 for Little Rock, Arkansas has him apparently living with a wife, Gussie. No trace of that marriage has been found and his death certificate gives him as single (brother Tom was the informant).

\section{Nicholas 1767, L1.2: G3-G5 - Chowan, NC}

Although the first Nicholas of Line 1 lived at Bertie, his two younger sons, Nicholas and William lived at Chowan, across the Chowan River. In 1795 a Tax List shows them both in Capt. Howcott's District, along with Wilson, the son of Joshua from Line $3 .{ }^{45}$ Family members were evidently remaining fairly close. !767 has been allocated as Nicholas junior's likely birth year, given the wording of his father's will, while April 1717 is given as his death date in court papers. 
Thomas Mewboorn 1688

Nicholas Mewboorn 1728
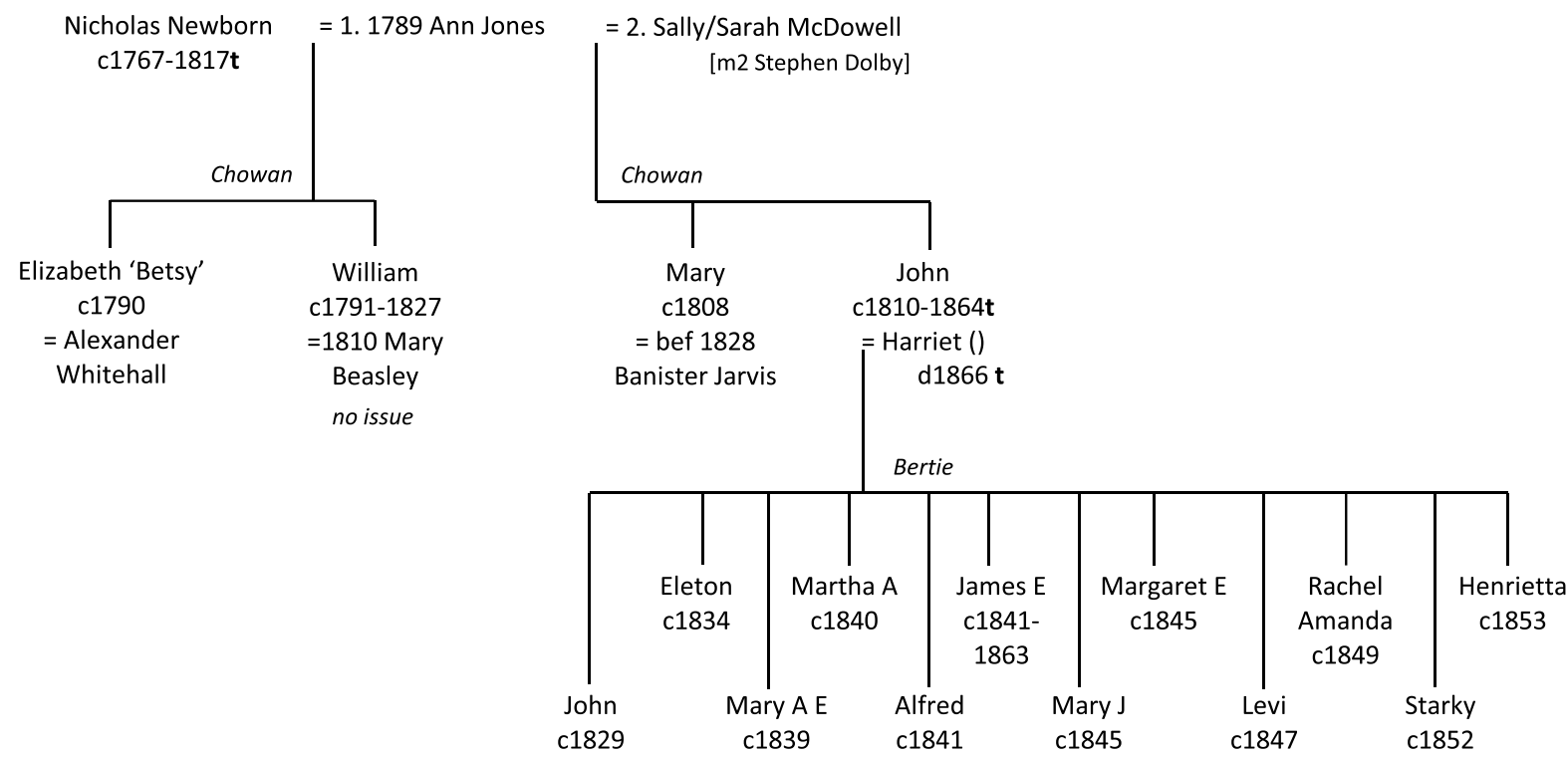

Figure 10. Descent from Nicholas Newborn, 1767, generations 3-5.

There is a marriage record at Chowan for Nicholas with Ann Jones in 1789. Later court records identify Betsy Whitehall as a daughter. They also show that his second wife Sally McDowell married Stephen Dolby, and in 1820 asked for 60 acres as her dower in the name Mrs Dolby. ${ }^{46}$ There is evidence for son William as a heritor when slaves were apportioned in 1824, and then evidence of his death when the slaves were reapportioned in 1827. A marriage of William to Mary Beasley in 1810 is not known to have had issue.

Nicholas's second marriage is known only from court papers from 1821, after his death. ${ }^{47}$ His wife's identity as Sarah or Sally McDowell is known from a petition lodged by William Bains and his wife Winifred that appears as a Sales Paper (image 20630) in the Nicholas Newbern estate where Bains was looking to claim against land formerly belonging to Stephen McDowell and where he describes a daughter of McDowell's as "Sarah intermarried with Nicholas Newbern." ${ }^{48}$ She also appears in her father's will which names "My Two Daughters Winifred Leighton and Sarah Newbern". ${ }^{49}$

In 1824 there is a court petition brought by Stephen Dolby at Bertie for the division of Nicholas's 'negroes'. The division went first to Stephen Dolby in right of his wife Sally, then Alexander Whitehall in right of his wife Elizabeth, then William, Mary and John Newborn. This establishes that the picture of descent is correct with four children from Nicholas's two marriages.

There are, however, slight incompatibilities among records relating to Mary and John.

Enumerated censuses in 1800 and 1810 show young people in the household that could be Mary and John - both being said to be under 10 in 1810.

There are guardianship papers showing John, orphan of Nicholas, placed in the care of Alexander Whitehall (presumably Betsy's husband) on the $9^{\text {th }}$ of December 1829 (having first been placed with his cousin William J). The papers are at Currituck, perhaps signalling the start of a long association with that County. The guardianship was renewed on the $27^{\text {th }}$ of February 1832 in the name of Zack Bray also at Currituck and indicating that John was still under age, so perhaps not born until 1812, or later.

In a division of negroes in April 1828 John was said to be still a minor - compatible with a pre-1810 birth. However, he appeared as a householder at Bertie in 1830 so may have been born close to 1809.

John became a waterman plying boats between Bertie and Chowan from Mill Landing. The censuses of 1850 and 1860 suggest a birth year of around 1801 or 1805 - apparently overstating his age a little. From all these conflicting pieces of evidence 1810 has been chosen to be John's birth year, perhaps early in that year, since he is believed to be one of the young males appearing in the 1810 census. 
John had possibly six sons with a wife Harriet, mostly difficult to trace:

- There is evidence of a John junior when Harriet petitioned for a dower in February 1864. The allocation mentions a boundary line with land of John Newburn Jnr. This John appears to have been born around 1829 and also plied his trade as a waterman at Mill Landing. John appears below.

- Eleton was born about 1834 and is characterised below.

- Alfred appeared in the 1850 census but thereafter there are no records for him.

- James E. was with the family in 1850 and 1860. He enlisted in Co. G, North Carolina $32^{\text {nd }}$ Infantry in April 1862. He died in October 1863, possibly while a prisoner of war, and was mustered out at Fort Delaware.

- Levi appeared at home in the censuses of 1850 and 1860 then vanished from the census records. However, his death is recorded at Edenton in 1919 when he was described as a widower. A marriage to May Coffield in 1895 at Chowan seems likely to be for him but May is equally elusive in the records and there is no evidence for any children.

- Starky appeared in the 1860 census but thereafter there are no records for him.

John 1829, L1.1.2.1: G5-G7 - Bertie, NC

John is a grandson of Nicholas, via his son John from Nicholas's second marriage to Sarah McDowell. John was a waterman at Mill Landing, like his father. He has not been found in the census of 1850 but appears at Bertie for 1860 (recorded in the next household to his father and registered as John Jnr), 1870 and 1880, first with Charlotte then with two Marthas. Marriage records from Bertie suggest he actually married five times and produced children from four of these liaisons - 15 in all as seen in figure 11.

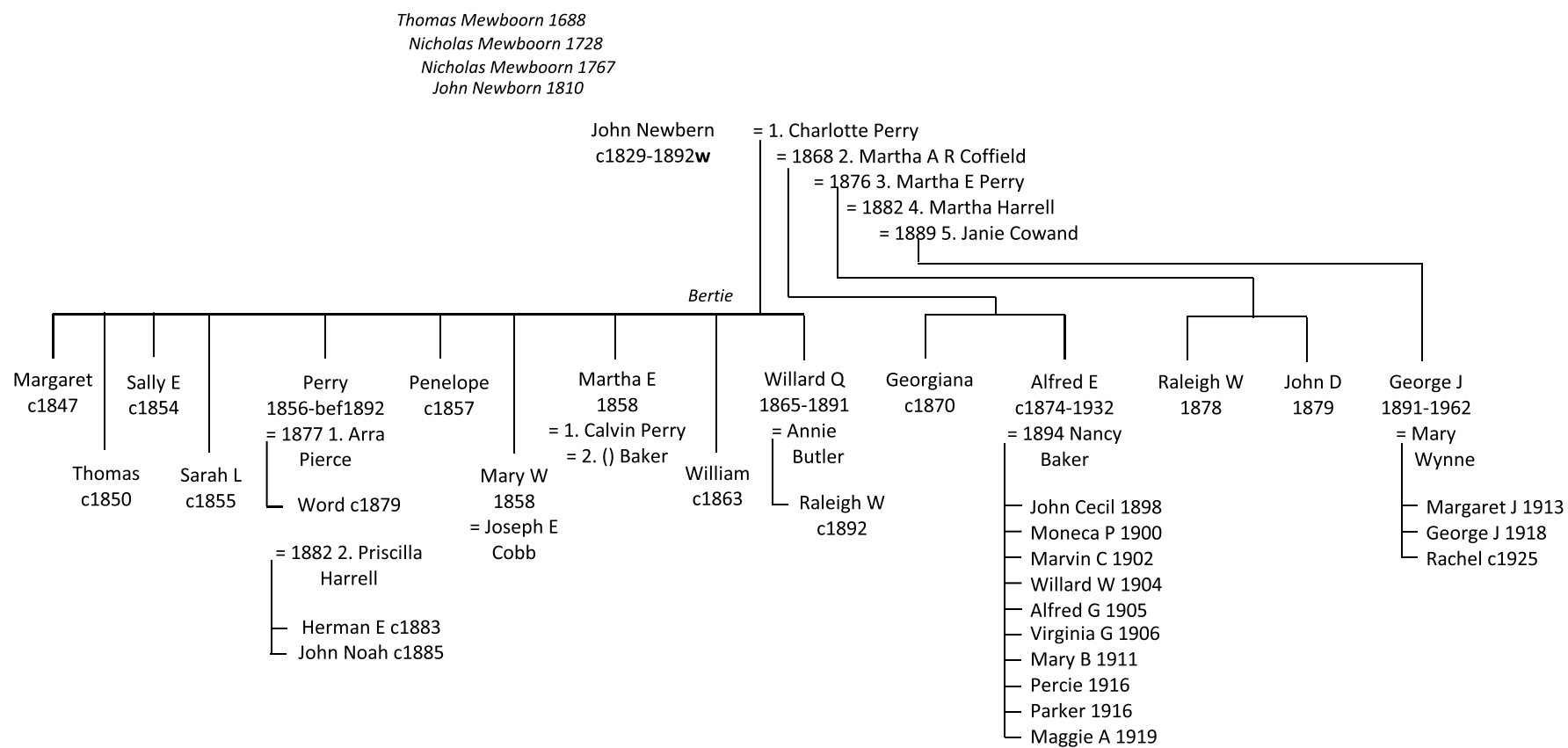

Figure 11. Descent from John Newbern, c1829, generations 5-7.

There were eight sons in all though only four are known to have married and had children. They were:

- Perry born 1856, from the first marriage with Charlotte Perry. He was himself married twice first with Arra Pierce in 1877. In 1880 he was working on Arra's father's farm and they had had a son, Word (apparently alive at grandfather John's death in 1892 though he has not been found subsequently). Arra evidently died soon after and Perry married Priscilla Harrell in 1882. There is of course no 1890 census for them, but Perry was dead by the time of his father's 1892 will. That will states that Perry had three children but by the time of settlement in 1899 only Herman and John were alive as heritors. Herman married Sallie Perry and had at least four children including one son before his death in in 1972, so the line may continue from there. John Noah married Lizzie Simons and farmed at Colerain where they had eight children including five sons, before his death in 1967. 
- Willard Q, also from the first marriage, died aged just 26 at Gould in 1891. He was working on his father's farm as a 15 -year-old in 1880 and married Annie Butler in 1886. A death record confirms that there was at least one son, Raleigh Willard born about 1892 (and he is named as a heritor from his grandfather's estate). Raleigh died at Nash in 1933 in an automobile incident, possibly from suicide although the death record is circumspect, recording death by "drowning (tho no eye witness to fall from bridge into river)." Raleigh also had a son, also Raleigh Willard.

- Alfred E was born about 1874 at Whites of the second marriage in 1868 to Martha Coffield. Alfred married Nancy Magnolia Baker in 1927 and they had 10 children at Whites before Nancy's death in 1927 and Alfred's in 1932 at Colerain. There were six sons to continue the line.

- George Judson was born in 1891 from the last of the marriages with Janie Cowand. They lived at Ahoskie in Hertford County where George became an auto dealer and had a son George Judson junior to continue the line.

Note. The settlement of John's estate in 1899 names two further heritors, Precilla Newbern (Perry's widow) and Narcissa J Newbern (could that be his own widow, Janie?).

Eleton 1834, L1.1.2.2: G5-G7 - Chowan, NC

Eleton was another waterman like his father. By 1860 he had his own household at Bertie and by 1870 was at Chowan as captain of a vessel. Things had taken a downturn by 1880 - wife Margaret was dead and Eleton was disabled, blind in one eye, reportedly through dissipation! Probate papers, in the name Ell (and sometimes Leonard), show that he died in 1881. Admon was assigned to a John Newbern, presumably his half-brother from 1829. It introduces some mystery, however, as the heritors are declared to be Arena Brown, Hattie Jane and Barney Arian. Arena/Irene and Hattie do not appear in censuses but figure 12 provides a compilation of possible children.
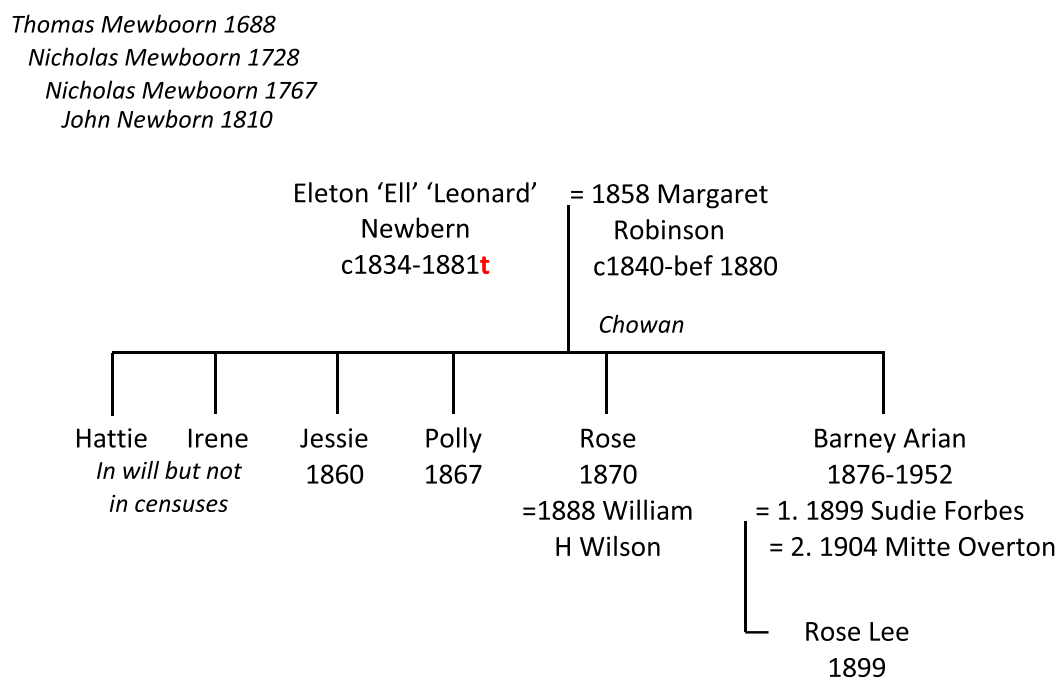

Figure 12. Descent from Eleton Newbern, c1834, generations 5-7.

The only son, Barney, also became a sailboat captain at Pasquotank, but the need for sail perhaps declined and later he worked as a labourer on a dredger in Virginia. He apparently had just one daughter from the first of his two marriages, so the line ended there.

\section{William 1769, L1.3: G3-G5 - Chowan, NC to Indiana}

Descent from Nicholas's third son, William, is complex involving significant migration and changes of name through Newborn to Newbern. He is listed as Newbern in the Tax List at Capt. Howcott's District, Chowan in $1795^{50}$ and that gives a good early fix for him. Census age bands from the 1790 to 1810 numerations suggest a birth between 1766 and 1774 . He is given an estimated date two years on from brother Nicholas.

William made a first appearance in the 1790 census at Chowan. That was on his own, since he did not marry firstly until 1792 with Judy Roggerson. He then appeared in the 1800 and 1810 censuses. We do not have a burial for Judy, but a second marriage was contracted in 1814 with Mourning Small. Two of his sons, William Jr. and Jeremiah were old enough to have established themselves independently as householders at Chowan by 1820, as was William's second wife, and widow, Mourning. In Mourning's case the enumerations fit exactly with her having all William's children in the household other than William Jr. and Jeremiah. 


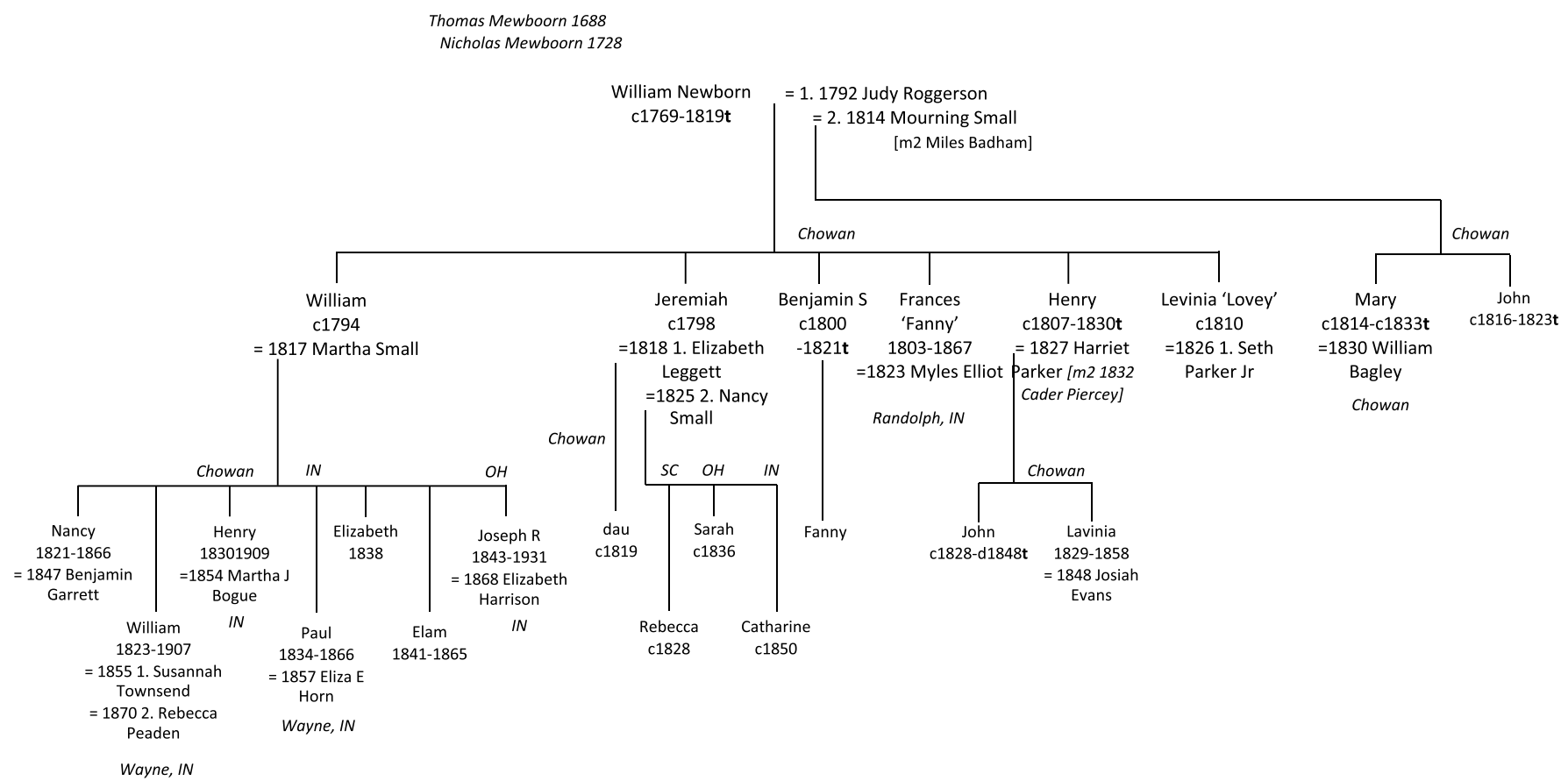

Figure 13. Descent from William Newborn, c1769, generations 3-5.

Birth dates for all the children are estimated relative to the marriage dates and appearances in court papers. William and Jeremiah were of full age by William's death, the others had guardians appointed so were all born after 1798.

- William Jr. contracted the second of this line's marriages into the Small family, with Martha, and raised his family at Chowan, appearing there in the 1820 and 1830 censuses. After that there were signs of significant migration. Later censuses show that by the late 1830's two of his children had been born in Indiana while the last, Joseph, was born in Ohio. In fact, William Jr.'s sons William, Henry Paul and Joseph all ended up in Indiana. No record for William's death has been found.

- Jeremiah married twice, the second time to yet another Small, but neither marriage produced sons. Information in the records for the daughters show that they moved to South Carolina, then Ohio and finally Indiana.

- Benjamin S is not easy to pin down other than through his death in 1821. At that point he owned property and slaves. Miles Badham was appointed administrator and probate papers name all the other children as heritors, thus providing further confirmation of who William's children were. Miles himself is a heritor as a result of his marriage to the widow, Mourning (Small).

- Daughter Fanny also went to Indiana, like Jeremiah, with her husband, Myles Elliot.

- William's youngest son from the first marriage, Henry, appeared in the 1830 census at Chowan (but died soon after). He had, however, married Harriet Parker. Their son, John, died at just 20; daughter Lavinia married but also died fairly young at just 29.

- Levinia, or Lovey, was the last of Judy Roggerson's children.

William's second marriage, to Mourning Small, produced two children:

- Mary, who married at about sixteen and died around nineteen. Her death generated more court papers that help understand the family.

- John, the youngest of all the children, was apparently numbered in the Chowan census with Mourning in 1820. Court papers following his father's death show that his guardian was Josiah Small, part of the close association between the Newberns and Smalls at Chowan. After John's death in 1823, when he was only about seven, further court papers show much wrangling over the re-distribution of property that he had been entitled to through inheritance from his father. A William gained administration, while a Nicholas was also bonded along with Myles Elliot. Elliot is the husband of Fanny, child of William Snr, so it seems likely that the administrator was her brother, William Jr. Nicholas might be their cousin, son of Thomas 1766, as there is no Nicholas among the children of William Sr.

William died without leaving a will and Mourning was assigned to be his administrator on the $14^{\text {th }}$ of December 1819 . An account was submitted on the $7^{\text {th }}$ of February 1821. 
William 1823, L1.3.1.1: G5-G7 - Wayne, Indiana then Ohio

William was the third of that name from the line of Nicholas and the eldest son of William and Martha 'Patsy' Small. He can be found farming at Franklin, Wayne County, Indiana in the censuses for 1870 and 1900 . In 1870 he was living with his younger brother Henry but with none of his children. His first wife Susannah had died, and he was yet to marry Rebecca; the children were scattered around.

By 1900 William was again widowed. He had retired from farming and was living with son Ollie and Ollie's first two children. William's children are confirmed in his will of 1902 which names "John W Newbern, Martha Ellan Barton, Mary Jane Duffee, George Newbern, Emma A Marshall, Clara E Newbern, Ollie Newbern, Amanda M Sieveke and my grandson Sherman Jeanes, son of my deceased daughter Judith Alice".

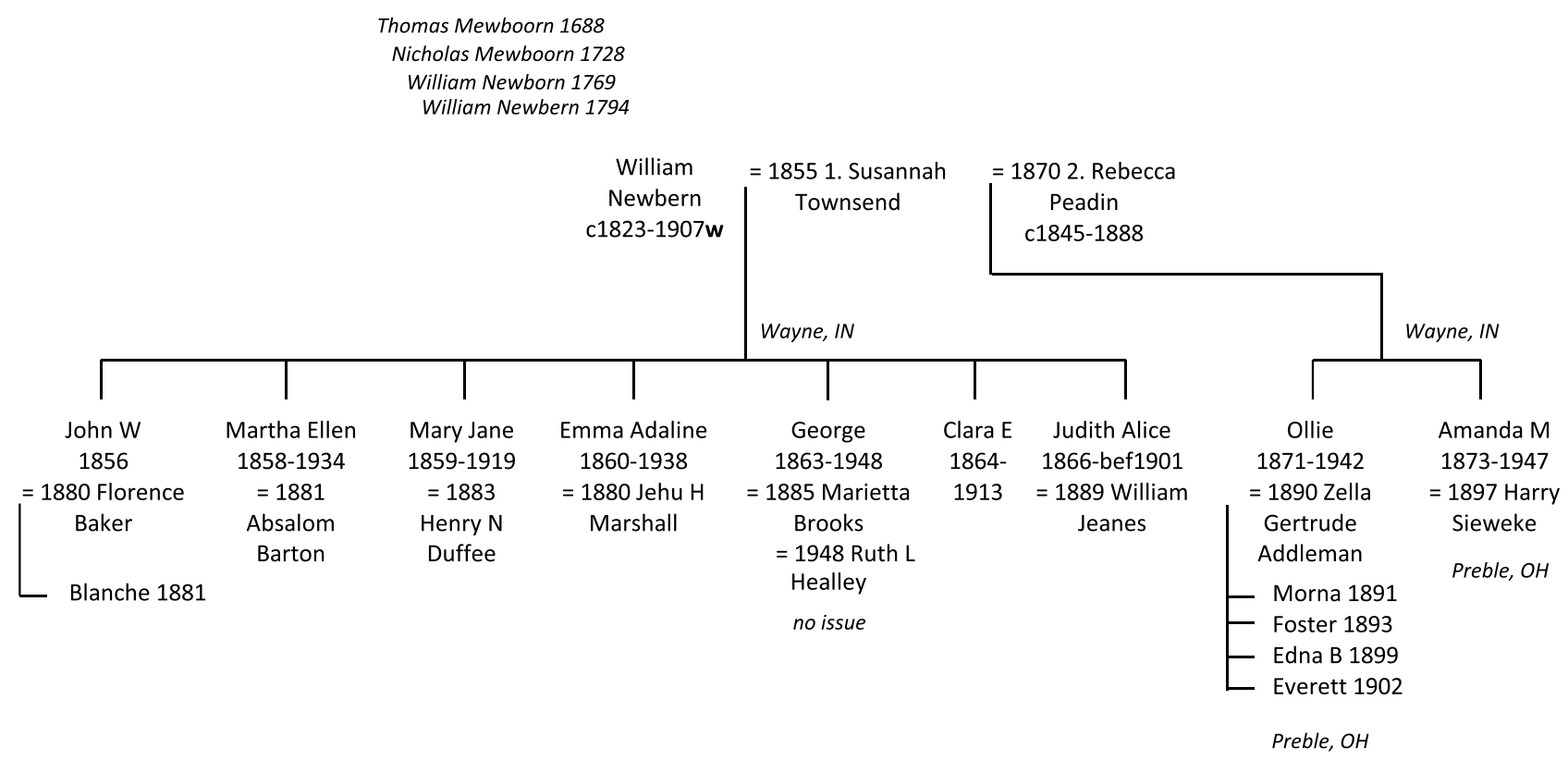

Figure 14. Descent from William Newborn, c1823, generations 5-7.

It is possible that the line continued from Ollie's sons. There were close links to Ohio. William and Rebecca Peadin were married at Preble, Ohio and both died there, though Ollie and Gertrude had both been born at Wayne and married at Whitewater.

Henry 1830, L1.3.1.2: G5-G6 - Franklin, IN

Henry, the second son of William and Patsy Small, listed himself as a farmer in 1860 at New Garden, then a farm hand at Franklin in 1870 and New Garden again in 1880. Henry married Martha Bogue in 1854. They were Quakers. There were no sons, so this line went no further. 

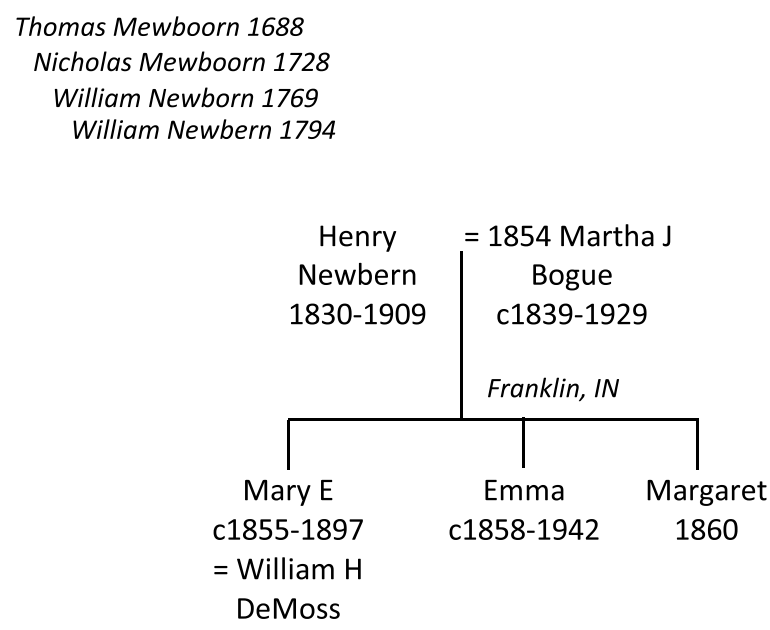

Figure 15. Descent from Henry Newbern, 1830, generations 5-6.

After Henry's death Martha lived with daughter Emma. Remarkably, in the 1910 census Emma claimed to be 28 rather than 52 and in 1920 went for 39 - she never married.

Paul 1834, L1.3.1.3: G5-G6 - Wayne and Miami, IN

Paul was the third son, born at Wayne in 1834. He married Eliza Horn at Wayne in 1857 and they had two daughters before his death from cholera at just 31. He appears at Richmond in the 1860 census with the whole family and was listed as a clerk. A Civil War Draft has him as a book-keeper.

\section{Thomas Mewboorn 1688 \\ Nicholas Mewboorn 1728 \\ William Newborn 1769 \\ William Newbern 1794}

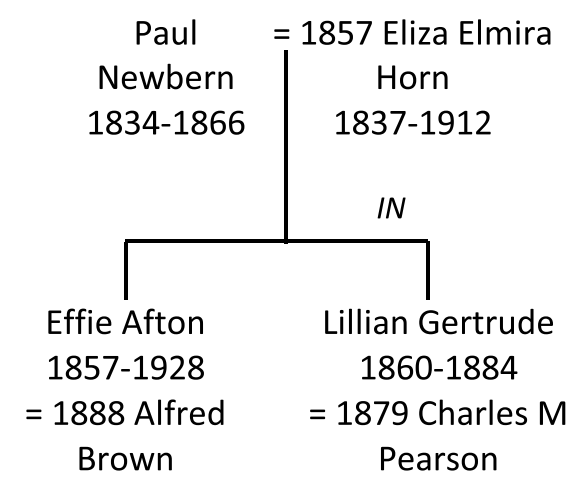

Figure 16. Descent from Paul Newbern, 1834, generations 5-6.

The two daughters married but the name line did not continue from here.

Elam 1841, L1.3.1.4: G5 - Franklin, IN

There is no tree for Elam. Technically he barely registers among the children of William and Martha. However, he featured in a significant historical event. He appears as a nine-year old in the 1850 census at Greensfork, Randolph in the household of Benjamin Garrett. Benjamin was the husband of William and Martha's first child Nancy, who is there in the household with her daughter, Amanda. Nancy's father, William, had died relatively recently and her mother, Martha, with siblings Elizabeth, Elam and Joseph were living with her in the Garrett household. The next significant record relates to Elam's death. 
Elam went to war, joining the Union army in Co. C of the $57^{\text {th }}$ Regiment of the Indiana Volunteer Infantry. He was taken prisoner by the Confederates then became part of a major tragedy when he was "lost in the wreck of the Sultana 27 April 1865." The war had just ended, and at Vicksburg the Sultana (with a legal capacity of 376) took on some 1,900 paroled prisoners from Confederate prisoner of war camps to ship them north. One of the ship's boilers had just been roughly repaired; the river was in flood and the ship was straining to go upstream; seven miles north of Memphis all three boilers exploded. The number of deaths is not certain but may well have been over 1,000 - the worst shipping disaster in US history. Elam was one of those who died.

Joseph 1843, L1.3.1.5: G5-G7 - Franklin, IN

Joseph was the youngest of William and Martha Small's children. He had a varied life being a grocer, salesman and buggy retailer - the last, in 1910, being perhaps unwise given the rise of the automobile. In the Anderson directory of 1930, he shows no occupation. He married Elizabeth Harrison in 1868 and they had two sons, Corman and Shirley to continue the line.
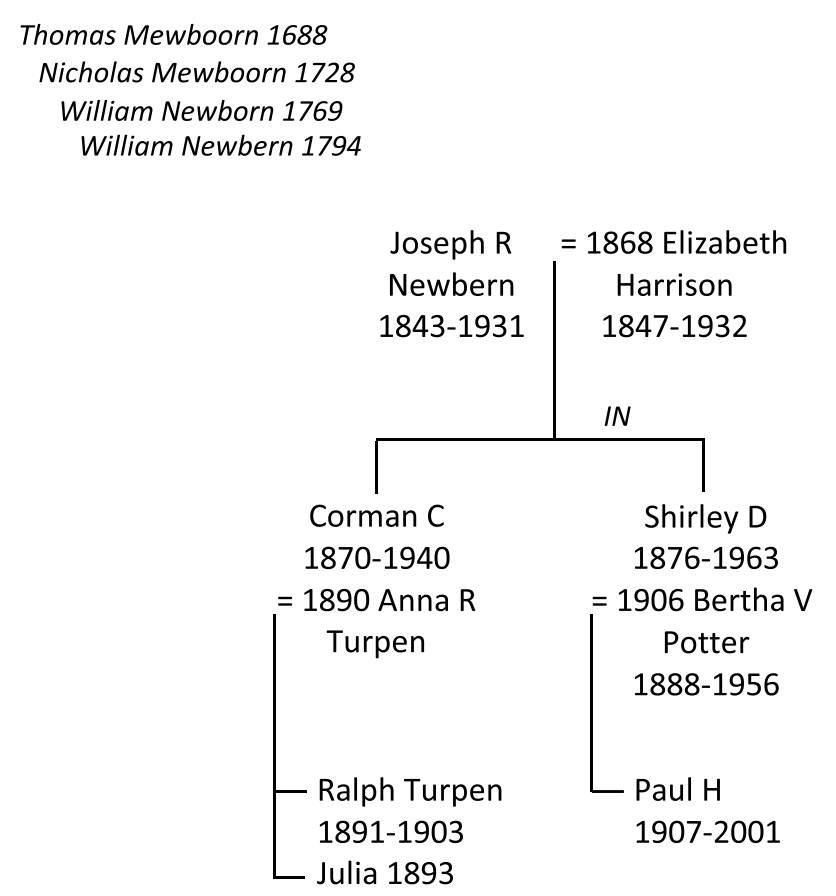

Figure 17. Descent from Joseph R Newbern, 1843, generations 5-7.

Corman had a son, Ralph, who died young and Shirley had a son, Paul from whom the line continued.

\section{LINE 2 - from Thomas Mewboorn c1729}

Thomas is believed to have been the second son of progenitor Thomas Mewboorn and has been given 1729 as his assumed birth year. He was a farmer and also a master cooper, which we know from his first appearance in the records when he accepted an orphan as an apprentice:

30 September 1767. William Ettenfield Warburton, orphan of Smithwick Warburton, aged about ten years, bound to Thomas Mewborn, Cooper. Signer:

Cullen Pollok. Witness: none. ${ }^{51}$

Thomas was also in the colonial tax list for Bertie County in $1768^{52}$ but then lived at Edgecombe (Edgecombe was formed from western parts of Bertie in 1741. Whether Thomas moved to Edgecombe or just found himself in it through the re-assignment has not been established. His presence in the Bertie tax list of 1768 suggests a later move, however).

Thomas died around 1782 so does not appear in Federal censuses. He did, however, leave a will (as Thomas Mewboorn) that allows us to make a start on defining the descent in this line. 


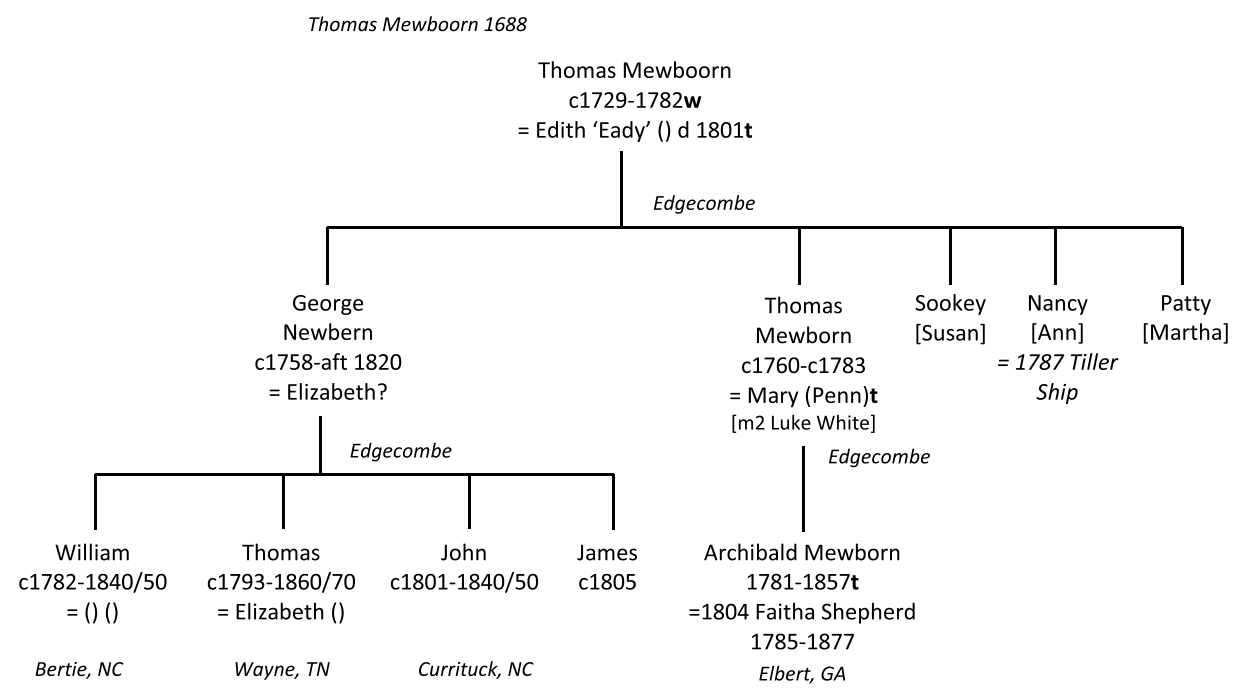

Figure 18. Descent from Thomas Mewboorn, c1729, generations 2-4.

The main part of Thomas's will of 1782 transcribes as follows:

I Thomas Mewboorn of the County of Edgcombe and State of North Carolina...

Item I do give and bequeath unto my son George Mewboorn The [Mannured] plantation whereon I now live together with all the Land to me belonging between the Little swamp and great Branch to him and his Heirs forever. Item I do give Unto my son Thomas Mewboorn all the Remainder of my Land not before mentioned to him and his Heirs forever. Item I do send unto my loving wife Edith Mewboorn One Negro wench Named Milly; during her Natural life and after my sd wife's decease it is my will that my Daughter Sookey Mewboorn Shall have the said Negro wench as I do give her to her and her heirs forever afterwards, Excepting the said wench shall have any Children hereafter it my will and hearts desire that my son George Shall have the first and that my son Thomas shall have the Next the Remainder to my said Daughter Sookey and her heirs forever. Item I do give unto my Daughter Nancy Mewboorn One Negro Girl Named Rose to her and her heirs forever. Item I do give and Bequeath Unto my Daughter Patty Mewboorn One Negro Boy Named Samson to her and her Heirs forever. Item I do give and bequeath Unto John Cannady One Cow and Calf. Item I do give and bequeath unto my loving Wife Edith Mewboorn all the Remaining part of my living not before mentioned. In the next place I do make ordain and appoint my well Beloved friend Charles Lee and my loving Brother John Mewboorn my Lawful Executors in and to this my Last Will and Testament. Signed Sealed and pronounced to be the Last Will and Testament of Thomas Mewboorn this $22^{\text {nd }}$ day of April 1782...".

The will identified a wife, Edith (The Order of First Families of North Carolina gives Grace () as the name of Thomas's wife though with no source cited. It can be correct only if she was a first wife. There is no question that Edith () was Thomas's wife at the time of his death). It also identifies three daughters by pet names, Sookey, Nancy and Patty, and two sons, George and Thomas. George was the principal beneficiary of the will and apparently the elder son. Nothing in the wording suggests that either son was under-age, therefore they were born 1761 or earlier. Dates close to that have been allocated to George and Thomas (but they could have been born as much as ten years earlier).

In 1801 there are court papers identifying William Rogers as the administrator for Thomas's wife Edith's estate when a writ claiming trespass was lodged by a Martha Mewbern. Then in 1803 there is writ against William Rogers as administrator for Judith Mewborn relating to costs awarded to Martha Mewborn. Martha may be the daughter 'Patty' named in Thomas's will, but it is unclear who Judith was. Might she have been a daughter of Thomas's son George?

\section{George 1758, L2.1: G3-G5 - Edgecombe, NC and some uncertain descent}

George is hypothetically an ancestor for some continuing lines of later Mewborns. However, proof for that is difficult to come by since there are no court papers relating to him and he lived at the time of un-named censuses. George inherited from Thomas at Edgecombe in 1782, but subsequent events are unclear due to a lack of records that identify his family.

There are no households at Edgecombe in the 1790 census, which is unexpected, but there is an entry for a George at Bertie. There are no other Georges of an appropriate age known among the Mewborn lines. We may suppose then that he set up home at Bertie while his father was still 
farming at Edgecombe and it was some time after his father's death before he decided to move there. There is a George at Edgecombe in the 1800, 1810 and 1820 censuses so we may presume that he moved between 1790 and 1800 . The patterns in these censuses are shown in table 2 .

Table 2. Edgecombe birth patterns from early censuses.

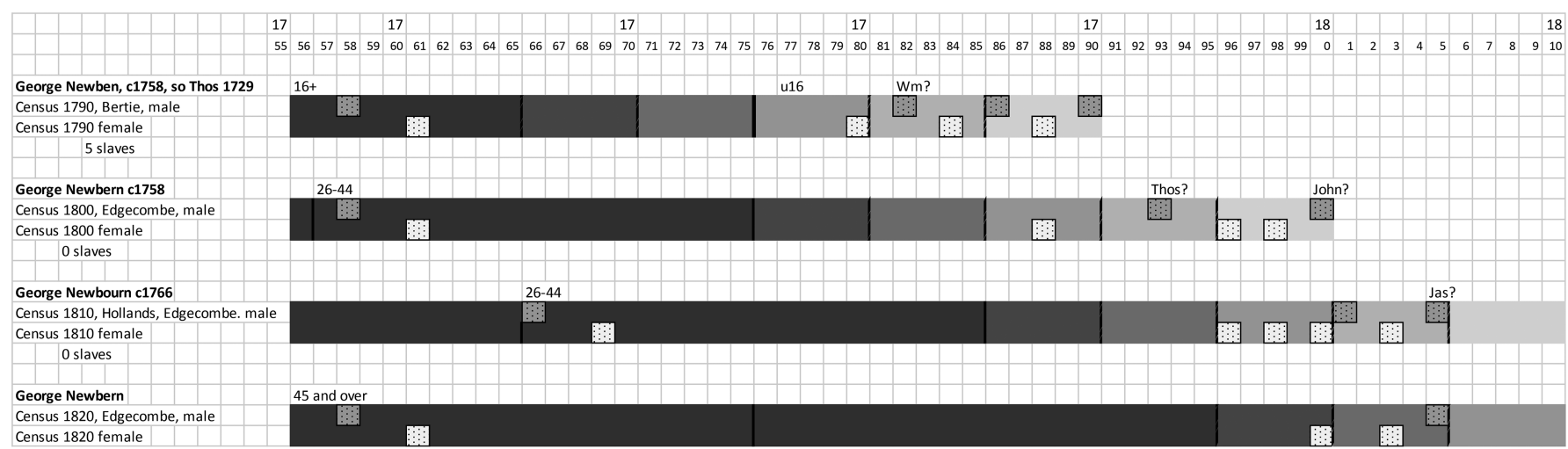

George has been allocated 1758 as a possible birth year. His father's will can be read that he was of full age in 1782 meaning a birth prior to 1761. It can also be interpreted to mean that he was older than his brother Thomas, to whom a birth of 1760 has been allocated. In George's case his appearance in censuses place him in age bands offering in one case an incompatible interpretation. In 1790 he is listed as over 16 , not very helpful; in 1800 his birth could be between 1756 and 1776; in 1810 between 1766 and 1786 (someway later than suspected), while in 1820 he finally is given as over 45 (pre-1775). The 1810 entry is at odds with the present interpretation of his father's will which suggests an earlier date. However, the other censuses can be viewed as consistent with an earlier date. His father's will has been taken as potentially more reliable than a census return, so an early date is preferred.

Note that George and his wife have been placed to match his supposed age deduced from his father's will. This is an example of the wish fulfilment that playing with the census patterns permits. He could equally be given 1766 as a birth year and then all four censuses would show compatible patterns with 1810 no longer seeming anomalous. However, that would be incompatible with the reading of his father's will. Note also that the positioning of the young males and females from 1790 is simply spaced every second year given the lack of age-specific information.

\section{George's household}

The pattern of household members found in the four censuses that George is associated with at Bertie and Edgecombe shows six young people born by 1790 and registered at Bertie, and another seven registered later at Edgecombe. The question then becomes, Who were they? Did they migrate from North Carolina? If so, are there plausible appearances elsewhere that can be matched to the rough years allocated to births for potential sons showing up here?

The males could show up as householders in their own right from about 1810 onwards. The next stage of investigation is, therefore, to look for plausible candidates of about the right ages and particularly, from 1850 onwards, who claim to have been born in North Carolina. Four candidates have been discovered and are hypothesised as possible descendants of George. They in turn offer possibilities of further descent. Note, however, that we are in the realm of hypothesis and no hard documents link the putative sons to George. Note also that five men are proposed as grandsons of George - William 1822 a possible son of the possible William from around 1782, and John 1816, Perry 1821, Sumner 1823 and Turner 1826 possible sons of the possible John from about 1801. The layers of supposition add to the level of uncertainty associated with these attributions even though they offer attractive means of tying up a few loose ends. DNA studies would provide the most convincing test of these hypothetical relationships. Figure 19 shows the patchy interpretation of descent from George. 


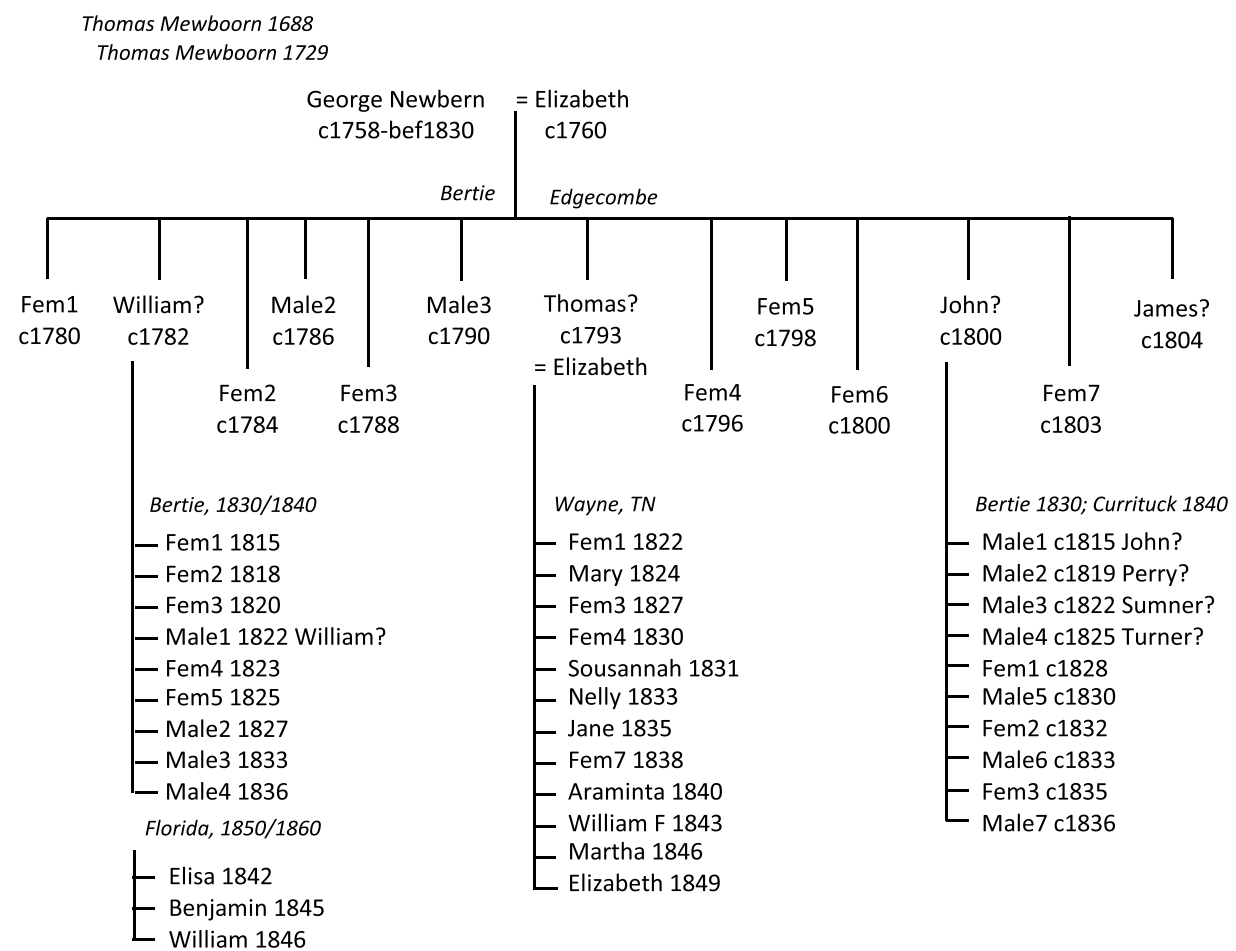

Figure 19. Hypothetical descent from George Newbern, c1758, generations 3-5.

At the 1790 census George had three males under 16 living with him at Bertie, i.e. born between 1775 and 1790 . These entries do not match with the Edgecombe censuses (other than the first male - now hypothesised to be William 1782) suggesting either some early deaths, or leaving home, or that George was looking after someone else's children, or even that we have two separate Georges (though that seems improbable as there is no evidence to make an argument for where a second one might have come from). The pattern of births suggests a move to Edgecombe around 1791-92.

In 1800, at Edgecombe, there is evidence for a further two males in the 1791-1800 bracket and three females in the same period. 1810 has another two males under ten (but no others besides George) - six males in total. All told, there may have been as many as seven young females, but they have not been traced. In 1820 George appears with a 16-25-year-old male (possibly one of the last two recorded males), a similarly aged female and an older female, presumably his wife. There are no other Mewborns at Edgecombe in 1820 so the males have either migrated or died.

There are no censuses showing any Mewborns at Edgecombe after 1820 and none for a George of the appropriate age elsewhere after 1820 so George is assumed to have died between 1820 and 1830 . His surviving sons could have been of an age to have appeared progressively with their own households in censuses after 1810 - although none appear at Edgecombe.

In fact, in 1830 (when George no longer appears) the names of three new householders appear in the censuses at Bertie. They are a 70-yearold Elizabeth (who had vanished, presumed dead, by 1840), a William and a John. The most likely explanation for them is that they are George's widow and two of his sons returning to their point of origin - that, at least, is the hypothesis offered. William and John could be almost twenty years apart in age and can fit with the first and fifth or sixth of the males from the early censuses. If any of George's other sons survived (and there are candidates) they could have migrated and established themselves elsewhere. The hypothetical framework for descent from George, is as follows:

William Newbern c1782, L2.1.1

William at Bertie in 1830 is of the right age to have been George's eldest son. He appears again in the 1840 census, still at Bertie. A William of the right age then appears at Duval, Florida in 1850, and again in 1860, latterly with a much younger wife. His stated age in 1850 gave an apparent birth date of 1780, while in 1860 it equated to 1783 . The estimate given here of 1782 fits neatly between these. He and his family may well, therefore, be descendants of George (appearing first in the 1790 census at Bertie) - DNA tests would be invaluable for confirmatory purposes. This line of descent seems reasonably secure. 
John Newbern c1800, L2.1.3

The John who appeared at Bertie in 1830 is said to have been born between 1800 and 1810 so can fit as a later son of George. He has been taken to be the fifth male in the household. In 1830 he had four young males in his household, one under five, two between five and nine and another one between ten and fourteen. There is no trace of this John at Bertie by 1840 and there are no candidates at Bertie for any of John's possible sons in 1840. There were, however, fresh appearances at Currituck - the easternmost county of North Carolina, beyond Chowan. Three Newbern households suddenly appeared there in 1840 - two Johns and a Perry. That, however, was not the first link with Currituck since, as we have seen, John (1812) the son of the second Nicholas and Sally McDowell had as his guardian Alexander Whitehouse at Currituck. Alexander was the husband of Betsy Newbern, John's aunt. There were family links to the area, though from a different line, from the 1820s through into the early 1830 s.

Several other Johns appear around the 1790s-1810s making this a particularly difficult migration to pin down with any great degree of assurance. The link from Bertie to Currituck is not clear, therefore, and only autosomal DNA testing is likely to resolve the relationships. What is presented here is a best guess for a strand of Newberns that thrives to the present day.

The elder of the two Johns is recorded as having been born between 1791-1800 (matching the age of the John recorded at Bertie in 1830, so possibly the fifth male recorded with George and the one who has been given 1800 as his birth year). He has not been found after 1840 . Perry's entry appears next to his on the census page, suggesting some closeness.

The younger John is said to be between 30 and 39 so possibly born 1801-1810. However, in 1850, 1860 and 1870 there is still a John at Poplar Branch whose age in those records gives a birth of 1815 or 1816 . Since there is no other John in that period it is likely that he is also the one in the 1840 census.

A possible match for Perry can be posited as one of the unnamed sons of the 1801 John. The Turner who appeared in 1850 can be matched to the fourth male from John's household at Bertie in 1830.

By 1850 the Currituck settlement had developed to be one household at Poplar Branch for John 1815, and two households at Knotts Island for Perry, whose age indicates that he was born about 1819, and for Turner born about 1825.

The Currituck migration was over a modest distance, if from Edgecombe, and since the settlers can be fitted to known birth patterns for descendants of George, it seems possible that they are indeed the right people and that we have identified some further descent from George. We can even extend the hypothesis by proposing Sumner Newbern from about 1822 who appears at Princess Anne in Virginia between 1850 and 1880 claiming North Carolina origin as being the third son of John, between Perry and Turner. The census patterns for Currituck are shown in table 3.

Table 3. Currituck birth patterns from early censuses.

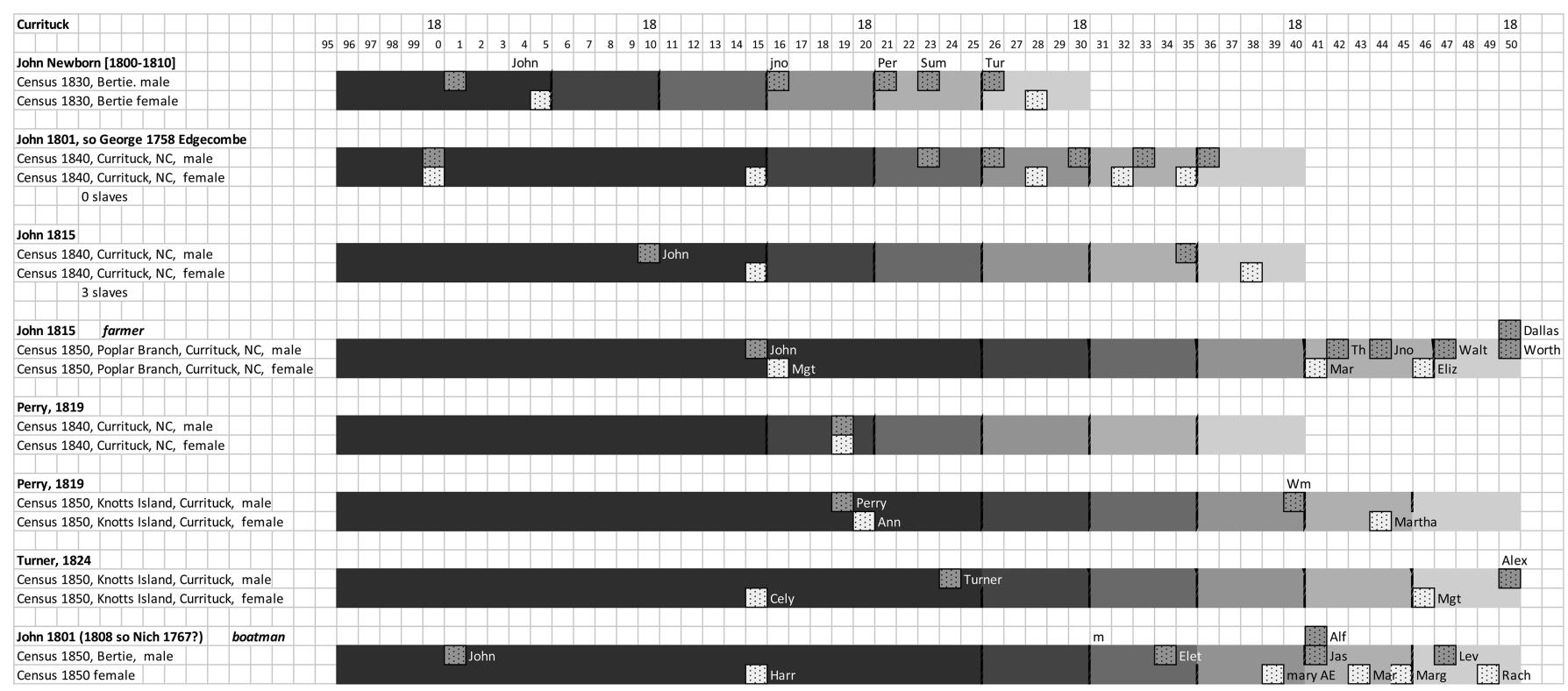


Thomas Newbern c1793, L2.1.2

A prime candidate for a more distant migration is a Thomas, according to his military record. He enlisted on the $11^{\text {th }}$ of September 1814 (while the War of 1812 was still going on) to the $8^{\text {th }}$ US Infantry and served 5 years, being discharged at Fort Gaines, Georgia on the $10^{\text {th }}$ of September 1819. He claimed to be 21 at the time of enlistment (so born c1793) and to have been born at Edgecombe - hence a candidate for descent from George. A soldier's land grant was made to a Thomas Newbern in 1819 - though the location is not stated in the online record. Land grants at that time were often made in Tennessee, an area that originally formed the westernmost part of North Carolina but had joined the Union as a State in 1796. A Thomas of the right age appears in censuses from 1830 to 1860 at Wayne, Tennessee (a plausible location) and he gives North Carolina as his place of birth. Thomas of Wayne, TN has been added to the hypothesis for George's descendants as possibly the fourth son. In 1850 Thomas and Elizabeth had seven daughters and a son, William F, with them at Wayne. They were alone in 1860 and the widowed Elizabeth was living with her (also widowed) daughter Nelly Flippo in 1870. Elizabeth was still looking after several Flippo children in 1880, and there may be a probate record for her in 1889. No further trace of the son William $F$ has been found after 1850.

James Newbern c1804, L2.1.4

Another migration candidate is the James who appears at Burke, NC In 1830. He is registered in the 1801-1810 age band (with a female 10-14). He could be the sixth son of George, notionally from about 1804. However, there is no further trace of him.

\section{Other considerations}

Two other males appeared in censuses in George's household at Bertie. Their births might have been around 1786 and 1790 . There are no candidates of appropriate age in North Carolina from 1810 onwards. If we wished to propose other lines descended from George, then we would need to seek candidates who appear in censuses at other places (i.e. who had migrated) but who are without clear antecedents. None has been found that seem worth pursuing.

\section{William 1782, L2.1.1: G4-G5 - Bertie to Duval, FL}

William 1782 no longer appears at Bertie after 1840. However, a William of about the right age turns up in Florida, as a farmer, in the 1850 and 1860 censuses with a young wife and family. In 1850 they were at St Johns Bar in Duval County where William registered North Carolina as his birthplace and gave his age as 74 (1776), while in 1860 it was 77 (1783). It is possible that this is George's son William of about 1782, seeking a new life after the death of a first wife (and the possible deaths of most of the children). Figure 20 shows what this might mean genealogically.

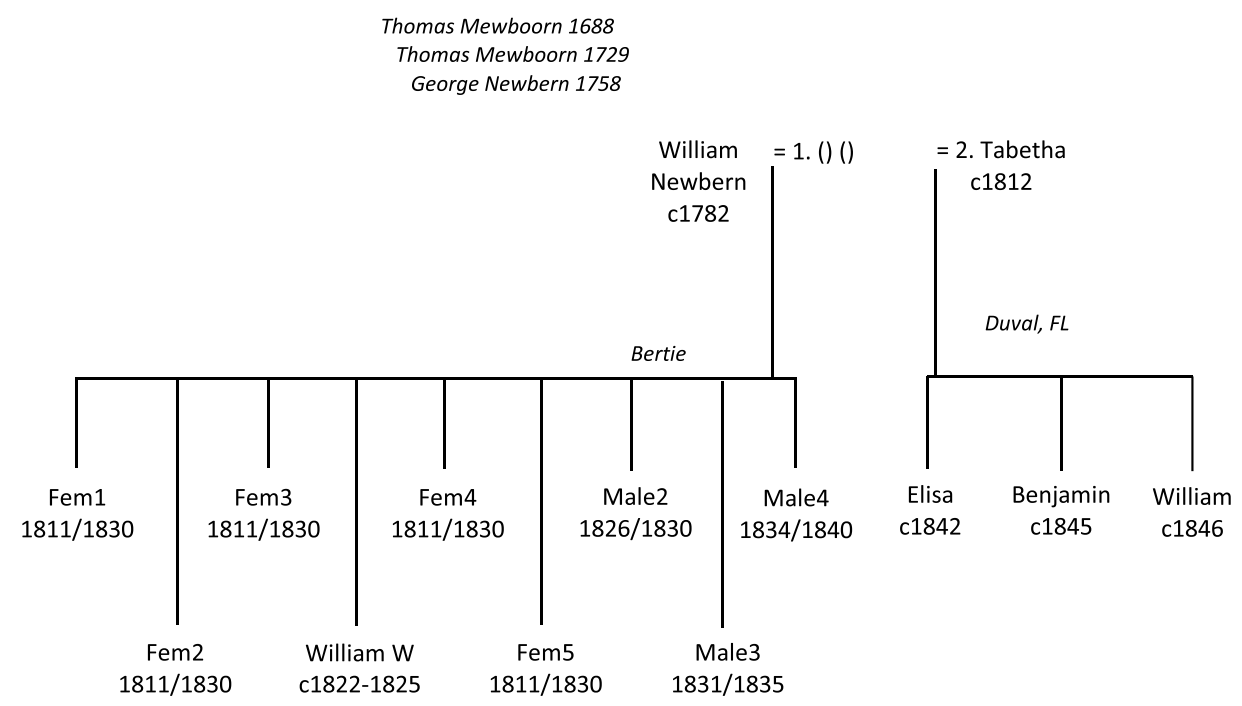

Figure 20. Hypothetical descent from William Newbern, c1782, generations 4-5.

Nothing is known of the Bertie family, if any of them lived. The only hypothetical link is to a William W of about 1822 . If we accept him then we have to accept the slightly unusual situation of there also being a William in the second family in Florida - perfectly possible but a little unusual.

Benjamin and Elisa were not with the Florida family in 1860, just William Jr. There is no trace of any of the children in Florida subsequently, so this line is assumed to have ended here. 
William 1822, L2.1.1.1: G5-G7 - Camden to Norfolk

By stretching our hypotheses yet further we might consider the William, born about 1822, who appears as a farmer at Camden, NC in the 1850 census. He could be a son of William 1782. He appears with wife Elizabeth and a family consisting of a daughter and three sons.

In 1860 he appears at Norfolk, Virginia with new Virginia-born wife Mary Creekmore. The four earlier children are present and one new son, John F. In 1880 the widowed Mary was living with two of her Creekmore sisters at Pleasant Grove and with three sons, John, Max and Robert.

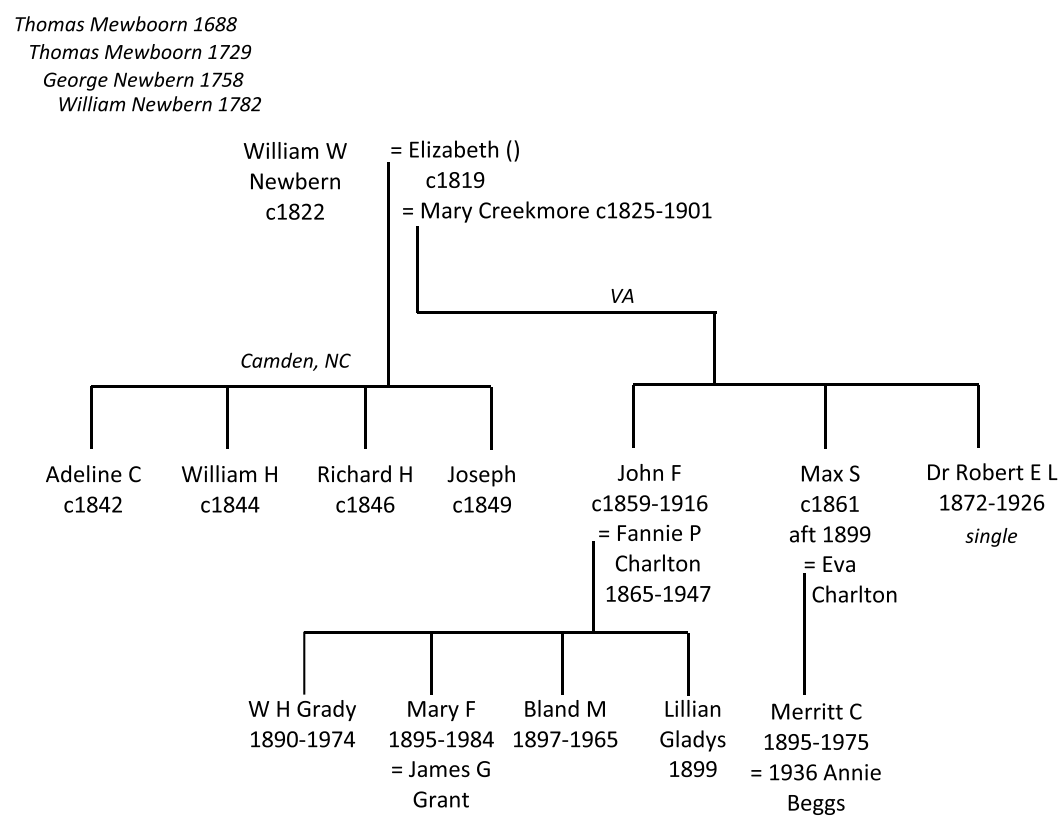

Figure 21. Descent from William W Newbern, c1822, generations 5-7.

John Franklin and Max/Mack Solomon married Charlton girls, Annie and Eva while Robert became a distinguished medical man but did not marry. Robert was a physician and dentist and became medical supervisor to the US Indian Service.

John's sons, Grady and Bland did not marry. Max's son Merritt married but is only known to have had a daughter, Anne. It seems that this line ended there.

John 1815, L2.1.3.1: G5-G7 - Currituck, NC

One of the Newbern households that appeared first at Currituck in the 1840 census was for a John Newbern. An hypothesis is that he was the eldest son of George's supposed son John of about 1800 . The memorial stone of this John Jr. at Coinjock gives his birth as the $15^{\text {th }}$ of June 1815. The implication, given the assumed birth date for his father in this hypothetical descent, is that his father was just 15 or so at his birth (though his father's birth year is not certain and could have been a year or so earlier) - young but quite possible. Again, DNA studies might help to provide assurance of such links.

John is believed to have had at least ten children. Six sons are known to have married and raised families. 


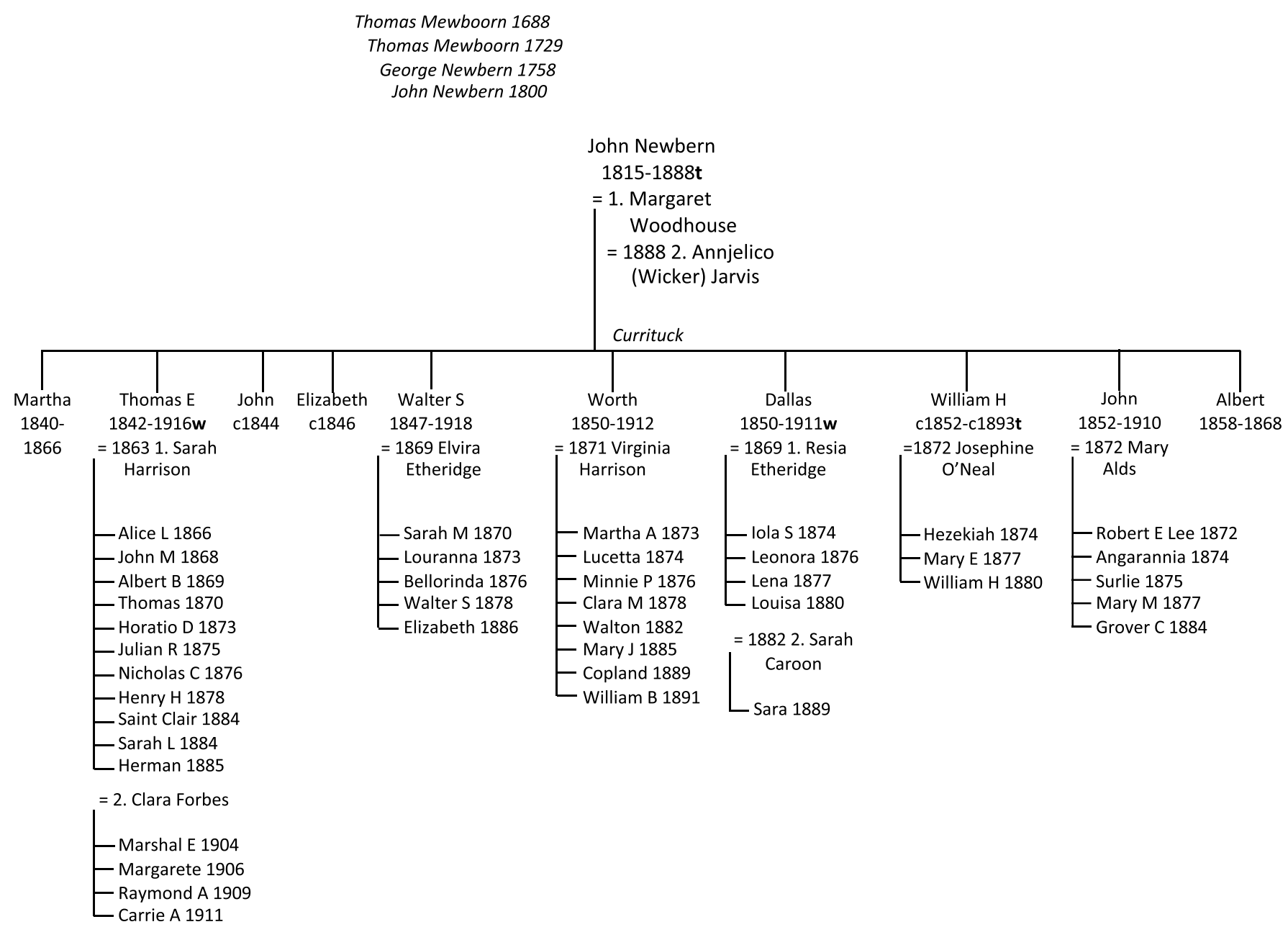

Figure 22. Descent from John Newbern, 1815, generations 5-7.

Of the six sons:

- Thomas E had a first marriage to Sarah Harrison in 1863 that produced eleven children at Currituck. A second marriage to Clara Forbes added another four. There were eleven sons in the fifteen children, and they provided over forty grandchildren.

Of those sons, there were nine by his first marriage to Sarah Harrison:

- John Melvin became a doctor at Jarvisburg, according to the Directory of Deceased American Physicians. He graduated from Georgetown University Medical School in 1898 and was licensed in North Carolina in 1899. However, there are some other records difficult to reconcile. He had apparently worked in Washington at the Office of the Quartermaster General as a labourer in 1895 on $\$ 660$ and in 1903 was listed as a clerk on $\$ 1,200$. Those records have the right age and state he was from Currituck. In the earlier instance he could have been working his way through school but why would he have been there in 1903? Was setting up in practice difficult or expensive (or could there have been some otherwise unknown John Melvin)?

- Albert Browning lived mostly in Oklahoma City appearing there in censuses from 1910 to 1940. Earlier though, in 1900, he had been more adventurous, operating as a general merchant in the Chickasaw Nation Territory. He had two sons to perpetuate the line.

- Thomas was also a general merchant in the Chickasaw Nation Territory, at Johnson, in 1900. By 1910 he was at McClain, then in 1920 in Texas, before returning to Oklahoma. He married twice and had a son by each marriage.

- Horatio Drinkwater farmed at Poplar Branch and appeared in censuses up to 1940. He and Fannie had ten children, five of them boys.

- Julian R. died young at Currituck.

- The splendidly named Nicholas Cutthroat farmed at Poplar Branch and had 13 children, 7 of them sons, by his wife Lillie Mae Dutcher.

- Henry H. died in infancy. 
- Saint Clair, after a spell at the University of Oklahoma, went into real estate, then banking, and from 1920 onwards was bank president at Byars. He had two sons from his two marriages.

- Herman farmed at Court House, Camden.

There were then two further sons, after a 19-year gap, from Thomas E's second marriage to Alice Forbes:

- Marshal Edward farmed at Pasquotank and had at least one son at Elizabeth City.

- Raymond Alton farmed at Nixonton, Pasquotank and he too had at least one son.

- Walter Scott Newbern farmed at Powells Point in Poplar Branch where he raised five children including a son, Walter Scott Jr. Walter Scott Jr. farmed at Elizabeth City and is buried at the Olds-Newbern Cemetery in Jarvisburg. He and Mattie Leigh had one son:

- Walter Relfe who studied medicine at Duke University and practised as a physician at Palm Beach, Florida.

- Worth farmed at Powells Point in Poplar Branch and appeared in all the censuses from 1850 up to 1910 . He was buried at the OldsNewbern cemetery at Jarvisburg in 1912. Worth and Virginia had three sons:

- Walton who by 1920 was retailing produce but by 1930 was farming in Florida. He and Sarah had no children.

- Copland farmed initially at Poplar Branch but had also moved to Florida by 1930 and was farming at Worthington Springs. Later the family lived at Gainesville and finally Copland lived at Alachua. There were two sons.

- William Benjamin is a bit of a mystery. In 1910 he was probably working as a bookkeeper in Norfolk, VA but he has not been found in subsequent censuses. He married at Pasquotank, and his wife and children are in the censuses for 1930 and 1940 at Elizabeth City (but not found in 1920). He certainly travelled and died as the result of an auto accident at Windsor in Bertie County.

- Dallas farmed at Powells Point and is found in all the censuses from 1850 to 1910. He was buried at the Newbern Cemetery, Coinjock. In his will he left the 50 acres he was living on to his second wife, Sarah Caroon, and the house to their daughter Sarah. There were bequests to the three other living daughters from the first marriage to Resia Etheridge. Dallas had only daughters, so that line ended with him.

- William farmed at Poplar Branch, Currituck. He appears there in the censuses from 1860 to 1880 . The only son, William Henry Jnr also farmed at Poplar Branch though, late in life, turned to carpentry. He too had a son William Henry who became a seaman.

- John spent his life farming in Currituck, ending up at Jarvisburg, as did two of his daughters and younger son Grover. Son Robert raised his family at Poplar Branch, Currituck, though he died at Elizabeth City, Pasquotank. Overall, the family remained wedded to Poplar Branch and can be found consistently in censuses from 1840 onwards.

- Son Robert was a farmer and retailer. He farmed at Poplar Branch, died at Elizabeth City and is buried at Jarvisburg. He and Mamie had ten children including four sons, one of whom died young, but the others may have continued the line.

- Grover farmed at Poplar Branch and was buried at Jarvisburg. He had 14 children by two wives, seven of them sons - so the line continued.

Perry 1819, L2.1.3.2: G5-G7 - Currituck, NC

In the murky descent from Thomas Jr.'s son George, it is proposed that he had a son, John c1800 and that he is the one who appeared in censuses at Bertie in 1830 and Currituck in 1840. Names are not known from these censuses but the age patterns for household members suggest a second male born around 1819. A Perry of the right age appears at Currituck in 1840 (presumably having moved with his father) and then at Knotts Island, Currituck in 1850, at which time he gave North Carolina as his birthplace.

This second layer of hypothesis proposes Perry as a son of John and a descendant of the Bertie Mewborns (though having adopted the Newbern name since George's time).

Perry's census entry in 1850 describes him as illiterate and with no occupation. He does not appear in subsequent censuses so is presumed dead before 1860. This is confirmed by the re-marriage of wife Ann to Miles Sawyer in 1856. She appears in the 1860 census at Tulls Creek, Currituck with five Sawyer children (probably all from a previous marriage of Miles) and with William and Martha Newbern, presumably Perry's children. 


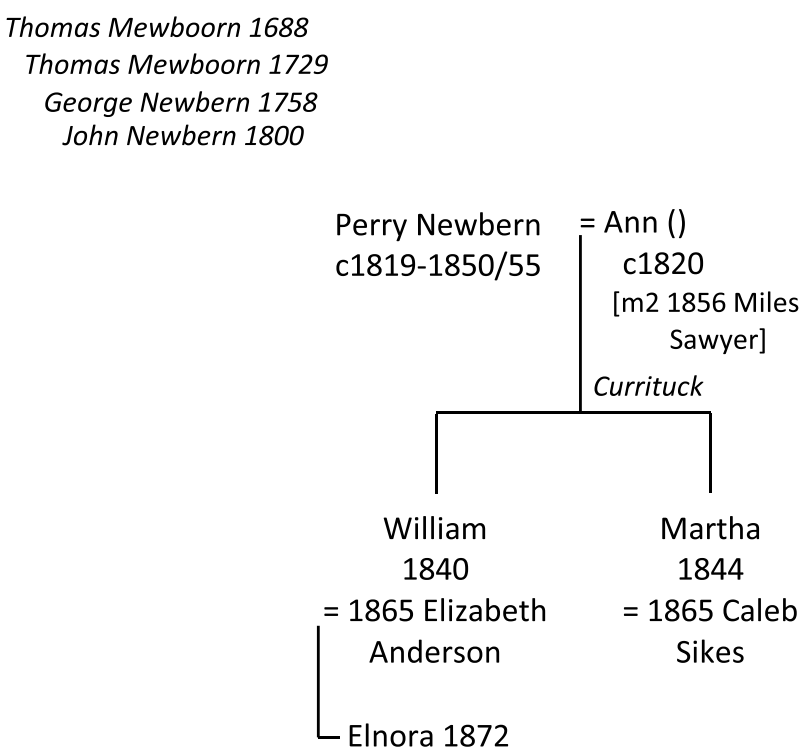

Figure 23. Descent from Perry Newbern, 1819, generations 5-7.

Perry's son William married but is not known to have had a son, so this line ended.

Sumner 1822, L2.1.3.3: G5-G7 - Currituck to Virginia Beach

Continuing with our hypotheses we propose Sumner to be the third son of John c1800 the supposed son of George. An issue here is that Sumner appears in records only from Virginia.

An indirect link enables a suggestion that Sumner was also the brother of Turner. This is supported by the fact that in 1870 Turner is recorded at Pungo in Princess Anne, having earlier lived at Currituck. On the same census page as Turner there are households for a 25-year-old John (c1845) who has a child named Turner, and a 22-year-old James (c1848). John and James appear to be sons of a Sumner Newbern born about 1822 in North Carolina. Propinquity and cross-naming of children offer the possibility that Sumner was the third son of John 1801 (and the first to move to Virginia).

Another cross-naming clue as to this relationship is the fact that, Turner, named one of his sons Sumler. Sumner/Sumler is a fairly rare name so the link may not be coincidence. Sumner's son James named a child Sumler, so the spelling shift is also a family matter.

Records lead us on a merry dance when it comes to Sumner and his younger brother Turner. Both had daughters called Margaret though one was most often called Peggy and the other Margaret Ann. Sumner's Peggy appears as a six-year-old in 1850 and a sixteen-year-old in 1860 so a birth year of 1844 seems fairly secure. In 1880 there is a Margarette aged 34, living with Sumner and Susan, and listed as a daughter. There is then a Turner and John H, listed as sons. These sons, at 12 and 6, would represent late breeding success for Sumner and Susan so instead it is proposed that they are the sons of Margarette and that she is the widow of Sumner's son John (who did appear in the 1870 census with a son Turner of roughly the right age). Margarette is therefore a daughter-in-law rather than a daughter.

Various online trees describe a marriage of a Margaret to William Otis Ewell around 1863 (no record has been found) and a sizeable family. This Margaret is often given Turner as her father, but this must be wrong since Turners' daughter has a different marriage history (see next section). The 1870 census offers circumstantial evidence that Sumner is her father since the page with Sumner's household (where he is wrongly named Turner - thus adding to the confusion) also carries households for Sumner's sons John and James and has William Otis Ewell and Margaret as the next household to him. Further circumstantial evidence for Peggy marrying Ewell is the fact that her two youngest sisters also married Ewells, so the families were close. 


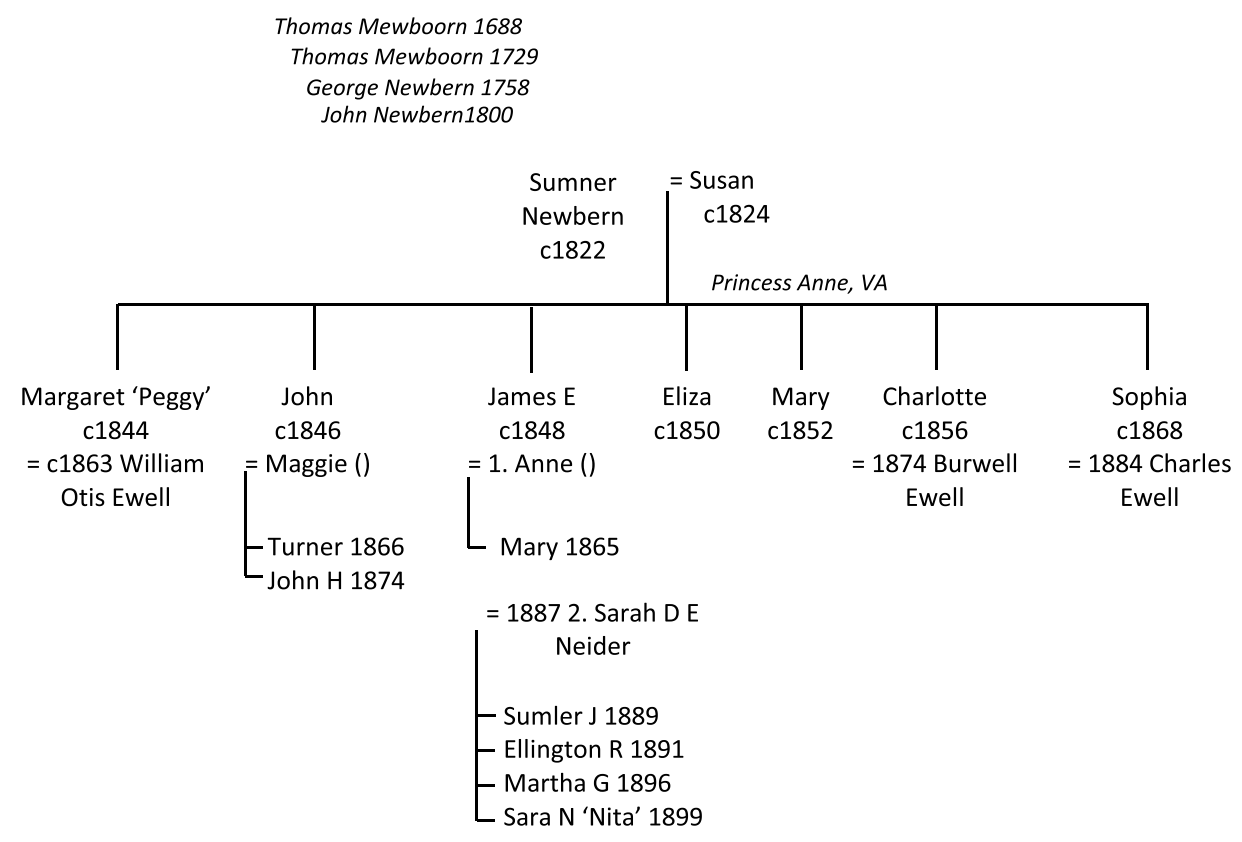

Figure 24. Descent from Sumner Newbern, 1822, generations 5-7.

Sumner and Susan had seven children, including two sons:

- John was born around 1846 and appears in the censuses from 1850-1870 at Princess Anne, latterly specifically Pungo. In 1870 he was living by "shooting wild food" and with a wife Maggie and young son Turner. He enlisted for the Union in F Co. Ohio $157^{\text {th }}$ Infantry on the $15^{\text {th }}$ of May 1864 and was mustered out on the $2^{\text {nd }}$ of September 1864 . His wife and two sons are believed to appear in the 1880 census with Sumner. Turner vanished thereafter while John Henry lived on to 1949 but did not marry.

- James Edward was born around 1848 and appears in the censuses from 1850-1870 at Princess Anne, latterly at Pungo. In 1870 he was living, like John, by "shooting wild food" and with a wife Anne and young daughter Mary. Anne evidently died and James Edward married again in 1887 at Bertie with Sarah Doskey Neider. James and Sarah had five children, four of whom survived and two of whom were sons.

- Sumler was a machinist at the Navy yard in Portsmouth and had at least eight children, seven of them boys to carry on the line.

- Ellington had two daughters.

Turner 1825, L2.1.3.4: G5-G7 - Currituck to Virginia Beach

In the 1850 census at Knotts Island, Turner has an entry on the page next to that of Perry. Based on propinquity he is proposed, therefore, as being another son (probably the fourth) of John c1800 who had moved to Currituck by 1840 . This is, however, an unproven hypothesis.

In 1860 there is a Turner living at Princess Anne in Virginia with children Margaret and Alexander who match the 1850 record. Princess Anne is just 30 miles north from the peninsula that is Knotts Island, so it seems likely to be the same family. Ages and names are given in varied ways in the censuses. Turner's wife is given as Cely then Sally but there is no evidence for more than one wife. The children are not well accounted for. Elington may be the Wilson who appears in 1860 but neither Charlotte nor Sumler appear in any census records. Instead, they are ascribed to Turner in death records. Turner and Cely/Sally do not appear in any records after the 1860 census and neither do sons Alexander and William. Confusingly though, in the 1880 census Sumner is mis-recorded as Turner (though appearing correctly with wife Susan) and this has led many family members astray in building trees. Figure 25 provides the resolution derived for Turner. 


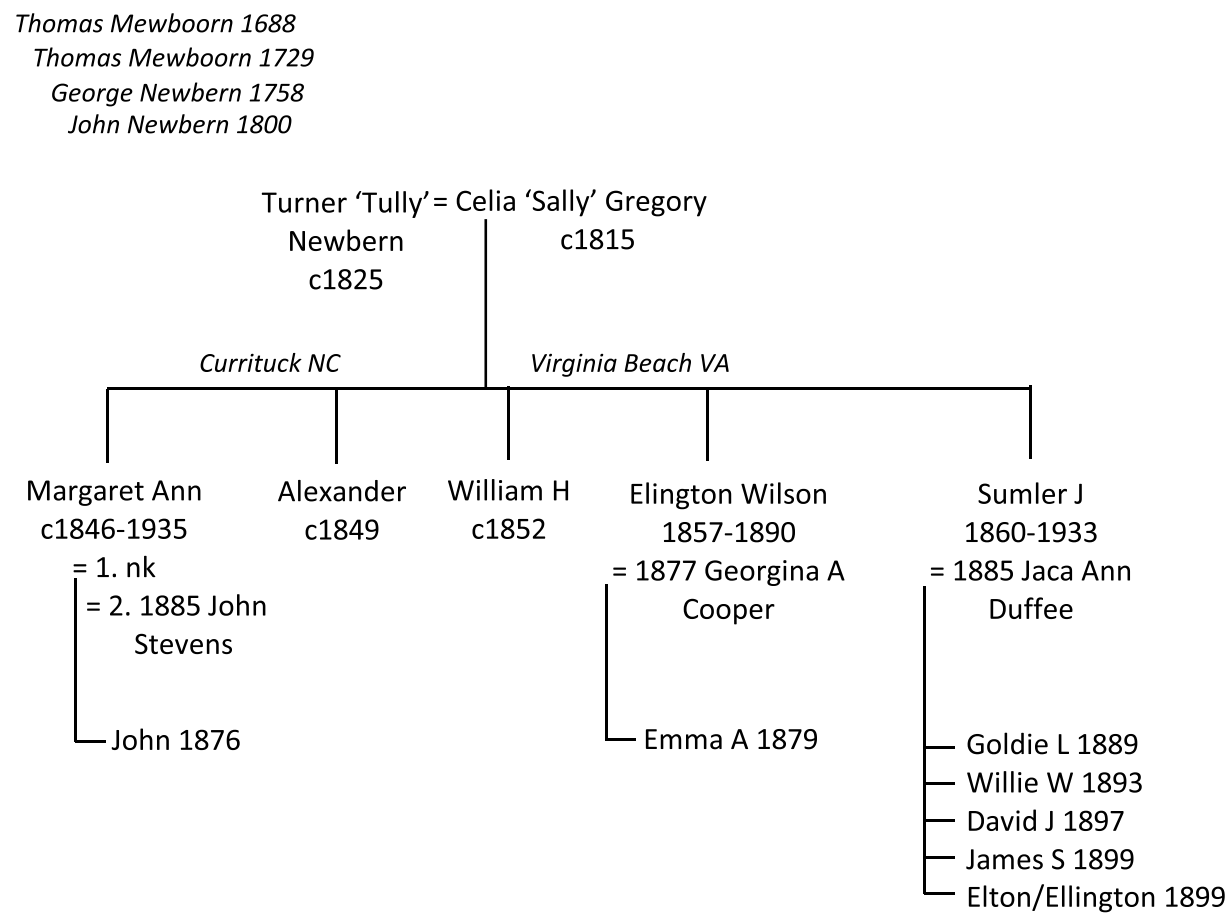

Figure 25. Descent from Turner Newbern, 1825, generations 5-7.

There are issues over Sumner and Turner's daughters, Margaret.

We can be fairly confident that Margaret Ann is Turner's daughter because at her death as Margaret Stevens her parents are named as 'William' Newbern (clearly an error on the part of the informant) and Celia Gregory, a distinctive mother. Several online trees have Margaret Ann as the wife of a William Otis Ewell, though there is no record for the marriage. William, however, lived until 1900 - clearly a separate life.

- Margaret Ann married John Stevens in 1885 and is named as the daughter of Turner and Celia. Margaret is noted as being a widow at her Stevens marriage yet marries in the Newbern name and has Turner and Celia named as her parents so, if there was a prior marriage it is well hidden. In the 1900 census Margaret and John have two of his children from a previous marriage living with them and also a stepson, John Newbern born June 1876. This son of Margaret's is either illegitimate or she married another Newbern, though there is no evidence of that. John has not been found subsequently.

- Alexander and William $\mathrm{H}$ have not been found after the 1860 census.

- Ellington Wilson probably appears as Wilson C in the 1860 census but as Elington in 1870 and 1880 . He married but had only a daughter.

- Sumler James was born and lived out his life farming at Virginia Beach. He married Jaca 'Jakey' Duffee in 1885. They had five children at Princess Anne, of whom four were sons to continue the line:

- Willie Windfield became a clerk in the US Navy. With Lillian O'Brian he had two children including a son, W Milton Newbern.

- David James was born in 1897. He became a clerk and was still at home with his mother in 1940. He finally married in 1960 with 51 -yearold Annie Manley but there were no children.

- James $\mathrm{S}$ is known only from the 1900 census when he was said to have been born in December 1899. Presumably his was an infant death.

- Elton (sometimes known as Ellington) Albee appears with his parents in censuses from 1910 to 1930. Death records give his birth as 03 December 1899. However, he is not named in the 1900 census. He may have been a twin to James $S$ and was being cared for elsewhere at the time of the census, or the James $S$ entry was simply an error. Elton married Gertrude Mathew in 1939. They have no child in the 1940 census, but whether they had any later is not known. 
Thomas 1760, L2.2: G3-G5 - Edgecombe, NC then on to Georgia

Going back up the line away from George's hazy descent and over to his brother Thomas we get to firm ground in the history of Line 2. Descent from Thomas via Archibald is well known and a 1790 land claim by Luke White, the second husband of Thomas's wife, states that Archibald was the only son. Archibald, though born at Edgecombe, moved to Elbert, Georgia where the family became well established and his 13 (or 16) children were born.

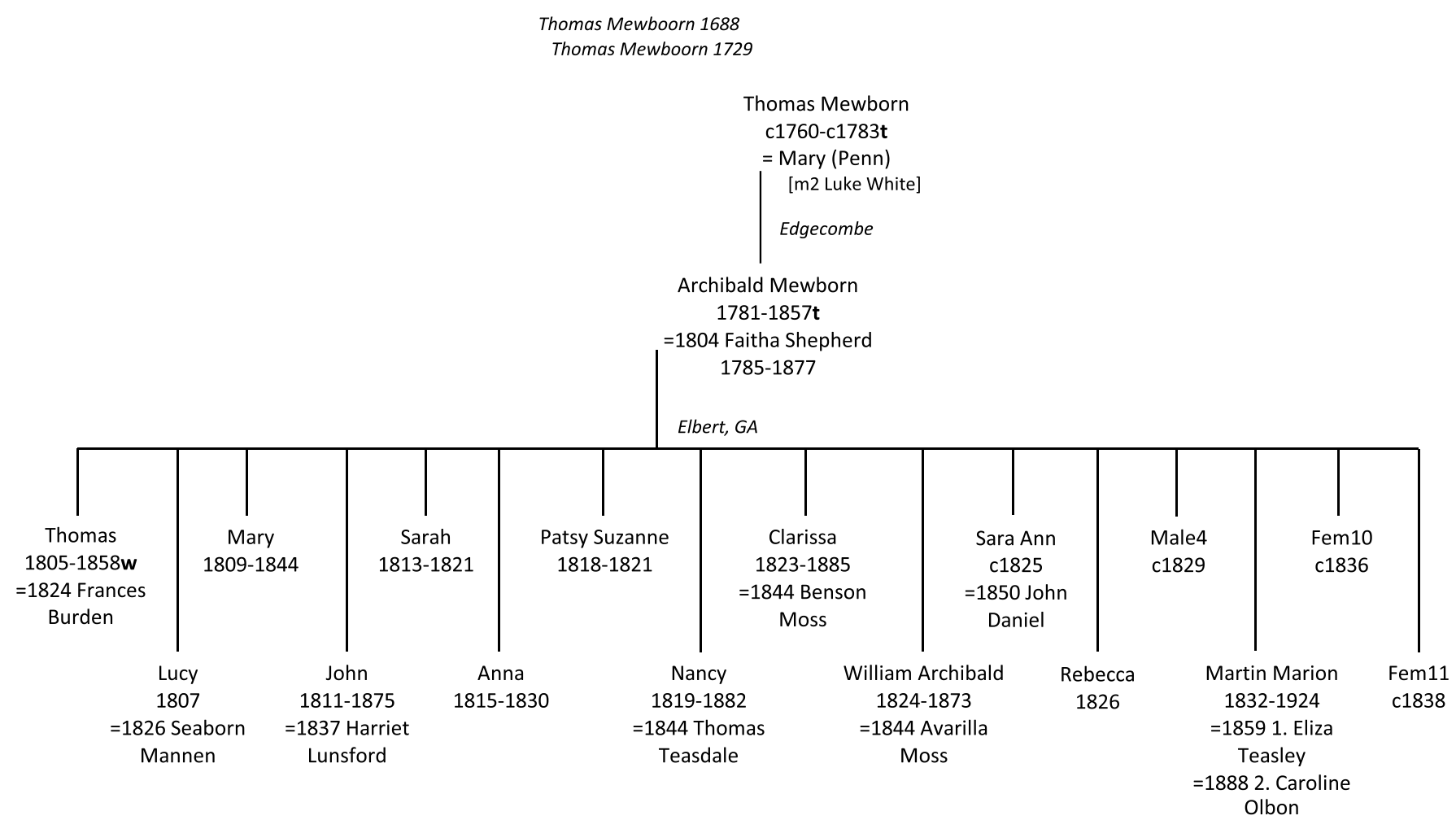

Figure 26. Descent from Thomas Mewborn, 1760, generations 3-5.

There are court papers confirming Mary as the executrix for Thomas's estate in 1783.

Some questions remain unanswered, however, over the number of possible children for Archibald and Faitha. Mary, Sarah, Anna and Patsy are names found in an online tree which have not been found in records. However, the numbers recorded (without names) in censuses from 1820 and 1830 do fit with their existence. Male4 matches one recorded at 1830 . Fem 10 and Fem 11 match ones recorded in 1840 - unless, of course, they are someone else's daughters just staying with Archibald and Faitha at that time.

By 1850 only Martin was still at home, so the unknown possible children had either died or vanished. Only the four named sons are known to have continued the line, but that is sufficient for present purposes.

Thomas 1805, L2.2.1.1: G5-G7 - Elbert, GA and Gwinnett, GA

Thomas was the eldest son of Archibald and Faitha at Elbert. He married Frances Burden in 1824 and raised a sizeable family at Elbert, most of whom moved to Gwinnett, though the eldest son, James, went to Alabama. Thomas appears in the censuses as head of household at Elbert in 1830, 1840 and 1850. He died and was buried at the Methodist cemetery in Lawrenceville - so had moved to Gwinnett County, where most of his children were living and where a great number of grandchildren were eventually born. 


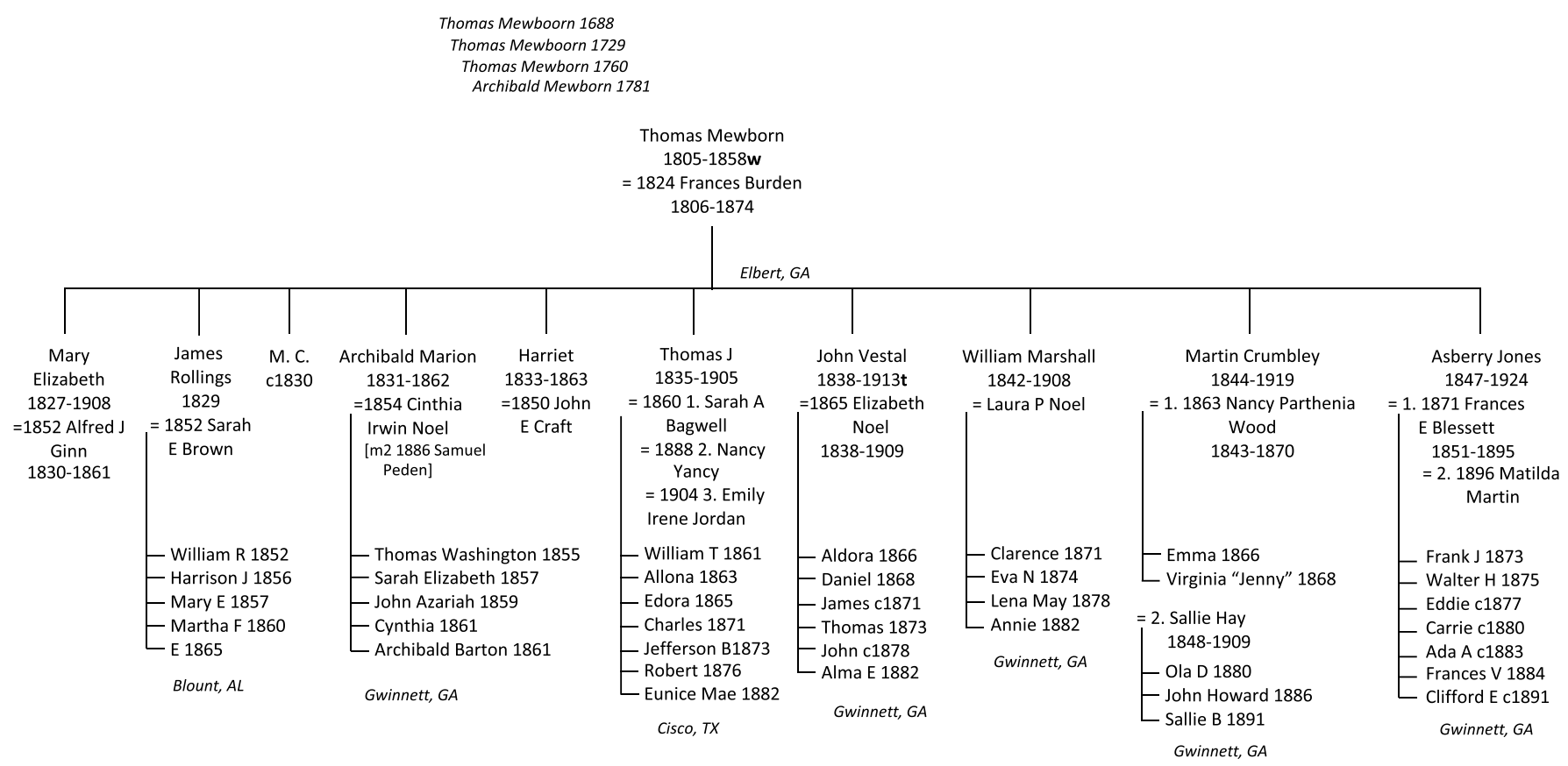

Figure 27. Descent from Thomas Mewborn, 1805, generations 5-7.

Thomas had seven sons all of whom married and raised families:

- James Rollings married Sarah Emeline Brown at Gwinnett in 1852 but by 1860 was farming at Blount, Alabama. He is believed to have had at least five children. He served in the Confederate army and was injured during his service. No record for his death has been found, however.

- Archibald Marion farmed at Gwinnett. He married Cinthia Irwin Noel at Gwinnett in 1854 and censuses show they had at least five children, including three sons to continue the line. Archibald is present in the 1860 census where four children appear, while the youngest is in the 1870 census with Cinthia. Archibald enlisted in the $42^{\text {nd }}$ Georgia Infantry Regiment on the $4^{\text {th }}$ of March 1862 but died at the Bean Station hospital in Tennessee on the $20^{\text {th }}$ of October 1862. Cinthia continued on the farm with help from the boys and eventually remarried in 1886 .

- Thomas Jefferson was born in 1835 and married Sarah Bagwell in 1860. They were farming at Hog Mountain, Gwinnett with their first three children at the time of the 1870 census. By 1880 they had moved to Yellow Creek, Dawson where Sarah died in 1886. They had had seven children. In 1888 Thomas is believed to have married Nancy Yancy and in 1900 was with her at Blanco, Texas. Thomas married again in 1904 with Irene Jordan but died five months later at Cisco, Texas. No children are known from any other than the first marriage.

- John Vestal was born in 1838 at Gwinnett and married Elizabeth Noel there in 1865. They farmed at Martins and had six children. Elizabeth died in 1909 and by 1910 John was living with his daughter Alma at Duluth where he died in 1913. He had served in the Confederate army from 1862 to 1865 in the $42^{\text {nd }}$ Infantry Regiment.

- William Marshall was born in 1842 and married Laura Noel in 1870. By 1880 they were at Duluth with the first three of their four children and by 1900 they were in Atlanta by which time William had joined the police force. He was buried back at Duluth in 1908.

- Martin Crumbley was born in 1844 and married Nancy Parthenia Wood at Gwinnett in September 1863. He was already in the army at that point having joined the Georgia $63^{\text {rd }}$ Infantry Regiment in January. They had two girls and were farming at Big Creek, Forsyth in 1870 just months before Nancy's death aged just 27. Martin then married Sallie Hay sometime around 1875 and in 1900, now farming at Duluth, they were in the census with their three surviving children. Sallie died in 1909 and in the 1910 census Martin was listed as a farm manager at Clarkston, DeKalb. He was buried back at Duluth Church Cemetery in 1919.

- Asberry Jones was born at Elbert in 1847 and farmed at Gwinnett. He married Frances Blesset in 1871 at Monroe and was farming there by 1880 . Asberry and Frances had seven children before she died in 1895. The following year Asberry married Matilda Martin at Forsyth and by 1900 they were farming at Pinckneyville in Gwinnett. They were still there in 1910 apparently with no new children. Asberry was buried at Duluth Church Cemetery in 1924. 
John 1811, L2.2.1.2: G5-G7 - Paulding, GA then Alabama and Texas

John was the second son of Archibald and born at Elbert, GA. He married Harriet Lunsford in 1837 and they had ten children at Paulding in Georgia before moving to St Clair, Alabama where their last three children were born. Note that they chose to enhance their surname to Mewbourn.

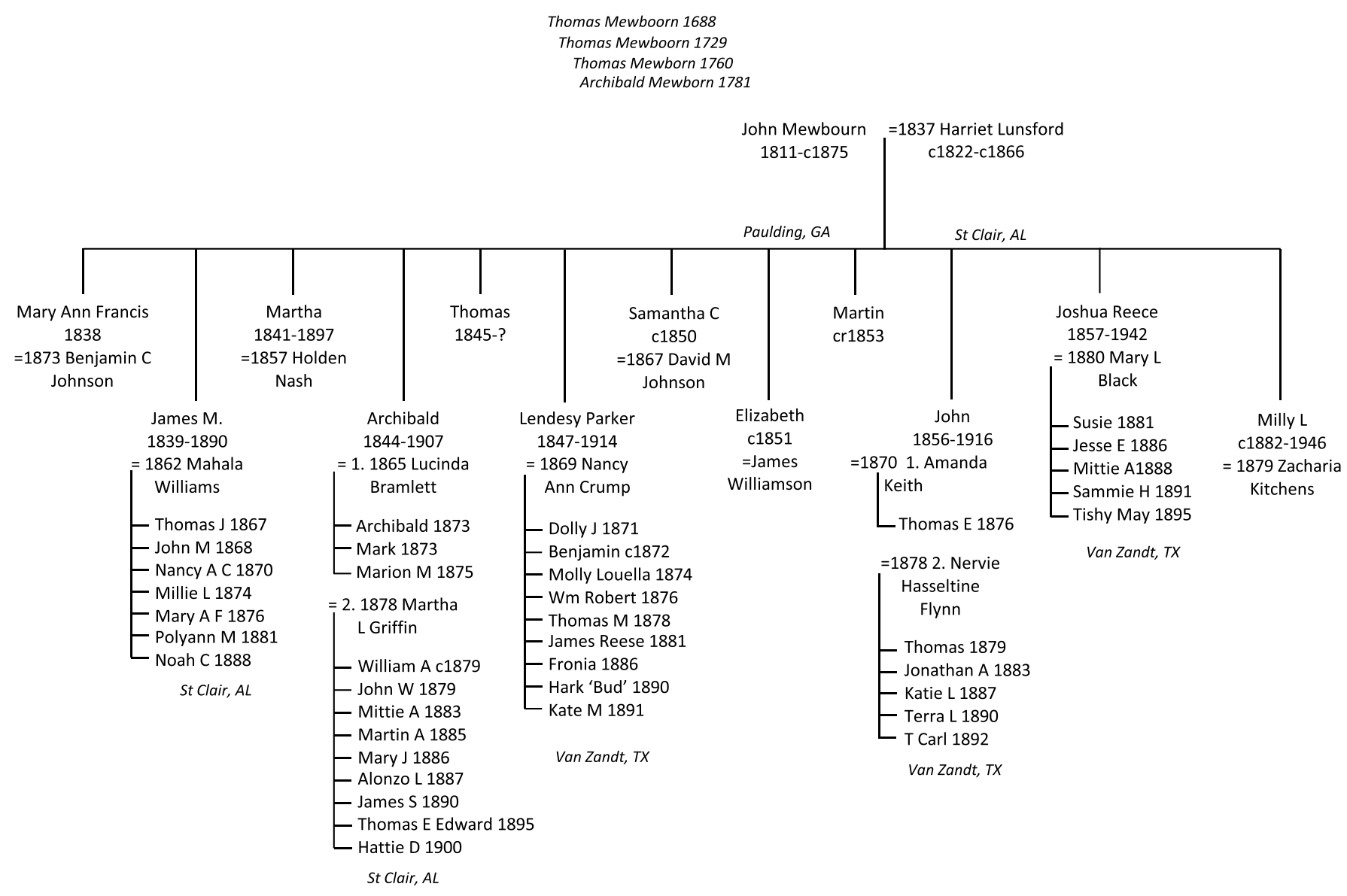

Figure 28. Descent from John Mewbourn, 1811, generations 5-7.

The two eldest sons raised families at St Clair but the other three headed off to Texas where they all lived in Van Zandt County, largely at Martins Mill.

- James M (records do not say what the M stood for) was born around 1839, at Elbert, then lived with his parents at Paulding. He was still with them in the 1860 census working on the farm after their move to St Clair, Alabama. In 1862 he married Mahala Williams at St Clair. They had seven children there, including three sons, latterly at Trout Creek. The line may continue.

- Archibald was born about 1844. He married Lucinda Bramlett at St Clair in 1865 and had three sons by her before her death in 1878. Later that year he married Martha Griffin and had a further nine children by her, six of them sons so the line should have developed well from there. By 1900 they were farming at Wilhites, Cullman County. Archibald was buried at Lauderdale, Alabama in 1907 and Martha in 1910.

- Lendsey Parker was born in 1847 at Elbert before doing a good deal of his growing up in Alabama. In 1869 he married Nancy Ann Crump at St Clair. They had nine children in Alabama and by 1900 were farming at Chepultepec in Blount County. By 1910, however, they had moved to Van Zandt county in Texas (still with the two youngest living with them). Lendsey died there in 1914 while Nancy Ann lived on until 1932 at Martins Mill.

- John was the first child born at St Clair, in 1856. He married Amanda Keith there in 1870 and they had one son. There was a second marriage to the gloriously named Nervie Hasseltine Satcher Flinn in 1878 and they had another five children at St Clair. They were at Chepultepec in 1900 but then, sometime after the last child was born in 1892, moved to Van Zandt. John died there in 1917 and Nervie in 1940. Some of their children lived on into the 1970s.

- Joshua Reece was the last of the sons in 1857. He married Mary Liza Black at St Clair in 1880 and they had seven children only four of whom were still alive by 1910. They were living at Van Zandt in 1900 with all the children listed as having been born in Alabama meaning they had moved between 1895 and 1900. However, in 1910 the listing claims the youngest was born in Texas which would 
mean an earlier migration. Tisha May continued to claim a Texas birth in subsequent censuses placing the migration between 1891 and 1895. Joshua, therefore, appears to have been the first of the family to make the move to Texas.

William Archibald 1824, L2.2.1.3: G5-G7 - Elbert, GA

William Archibald, Archibald Mewborn's third son, was born at Elbert and stayed and raised his family there.

William is found heading his own household in censuses at Elbert in 1850, then at McCurry, Hart in 1860 and 1870 . He died in 1873 and by 1880 his widow, Avarilla, was farming at Pike with just her youngest son Moses. In censuses William's family were typically rendered as Mewbourn, though at burial they reverted to Mewborn

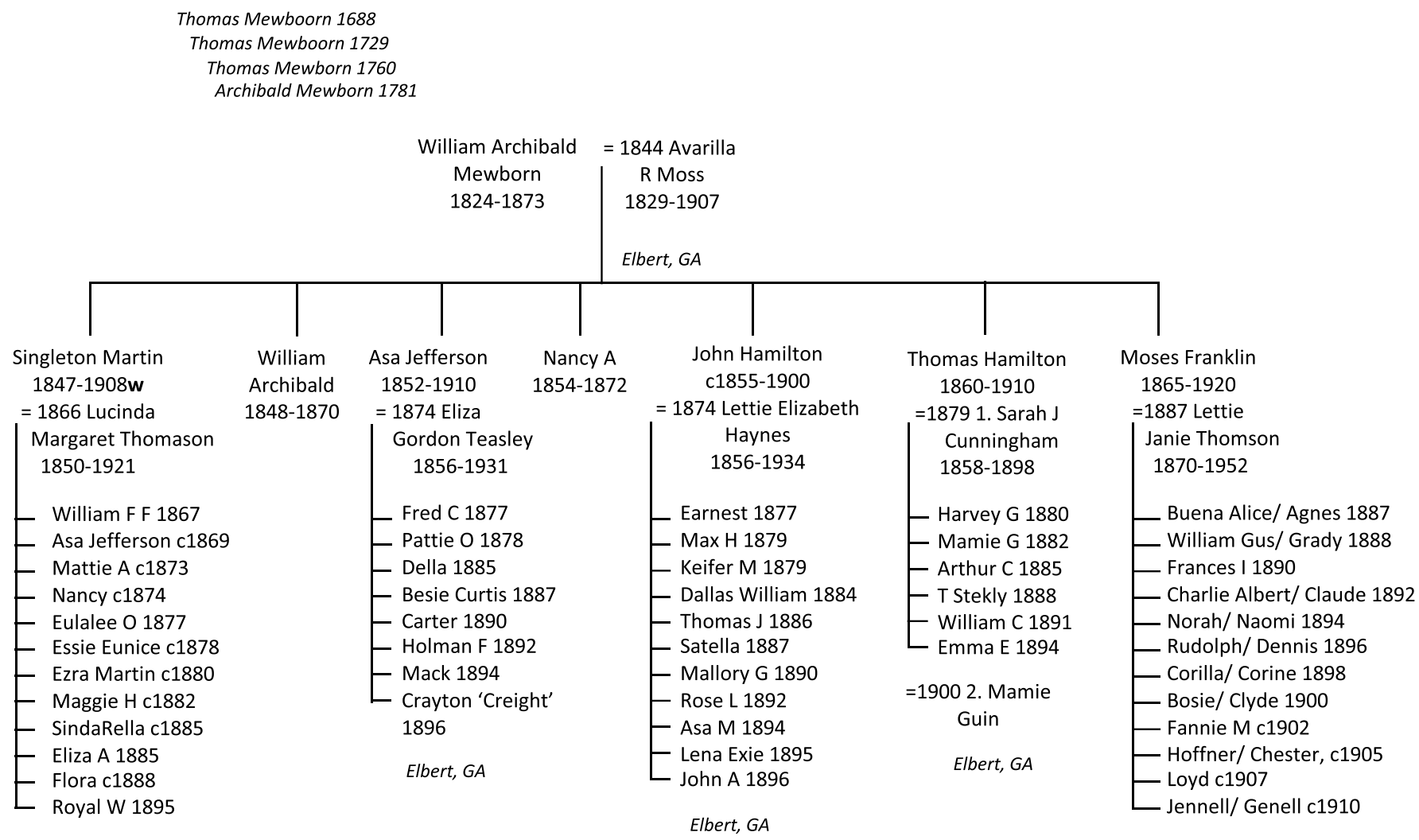

Elbert, GA

Elbert, GA

Figure 29. Descent from William Archibald Mewborn, 1824, generations 5-7.

Five sons from William and Avarilla raised families at Elbert:

- Singleton Martin was born at Elbert in 1847. He married Lucinda Margaret Thomason at Hart in 1866 and they had fourteen children (four sons) though only twelve were still living by 1900. Singleton died in 1908 and was buried at Holly Springs. He left a will, fairly uncommon in this family, with his wife being the principal beneficiary and bequests of $\$ 40$ being made each to Eulela, Ezra, Maggie and Eliza; with Roy (Royal) to get $\$ 140$ at his majority. Whether sons William and Asa were still alive at that point has not been established. They were last seen in 1880. By 1900 Singleton had adopted a Mewbourne spelling and he and his children were buried in that name.

- Asa Jefferson was born in 1852. He was working on his father's farm at McCurry in 1870 then married Eliza Teasley in 1874 and by 1900 they were farming at Centreville. They had eleven children but by 1910 just eight were living. Also, by then they were running a boarding house at Elberton. Asa died in 1910 and by 1920 Eliza was farming at Athens. Ten years later she was living at Clarke with daughter Curtis (though that may be an error in the census return. Probably she was really with the youngest, Crayton, who was 35 as the census suggests (Bessie Curtis would have been 43.).

- John Hamilton was born about 1855 and farmed at McCurry. He married Lettie Haynes in 1874 but died at just 45 in 1900 . By 1910 , still at McCurry, Lettie reckoned to have had fourteen children but with only nine still living. She was at Bowman by 1930 and died there in 1934. 
- Thomas Hamilton was born at Elbert in 1860 and married Sarah Jane Cunningham there in 1879. Six children are known before Sarah's death in 1898. Thomas married Mamie Guin in 1900 and though Mamie already had a daughter from a first marriage they are not known to have had children.

- Moses Franklin was born in 1865 at Elbert and lived and farmed there until his death in 1920. He married Lettie Thomson at Hart in 1887 and they had some twelve children, including six sons so the line may continue from them.

Martin Marion 1832, L2.2.1.4: G5-G7 - Hart, GA

Martin Marion was the last of Archibald's sons. He grew up at Elbert then in 1859 married the splendidly named Eliza Meanda Elmira Teasley at Hart. They settled at McCurry in Hart County where Martin is found in censuses from 1860 to 1920 . He and Eliza had 11 children before her death in 1888. Six months later he married Caroline Olbon and they had one further child. Martin died in 1924 and is buried at the Bethesda United Methodist Church cemetery in Hart.

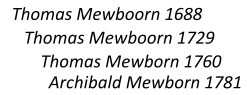

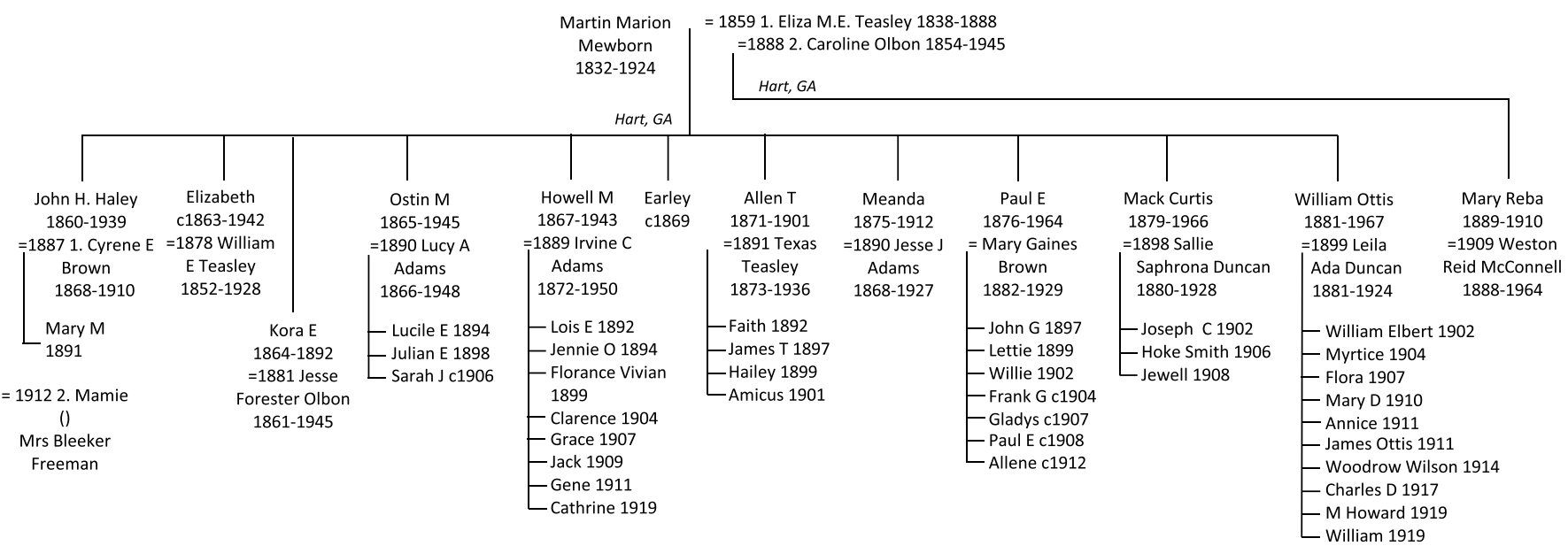

Figure 30. Descent from Martin Marion Mewborn, 1832, generations 5-7.

Martin Marion had seven sons to extend the line:

- John Haley was born in November 1860. He married Cyrene Brown in 1887 and they farmed at McCurry. They had three children but only one daughter survived. A second marriage to Mrs Mamie Bleeker Freeman (whose origins are not known) after Cyrene's death in 1910 produced no further children.

- Ostin Martin married Lucy Adams in 1890 and they farmed at Goshen where they raised their three children, before finally moving to Bowman. They favoured a Mewbourn spelling. Son Julian is not known to have had children.

- Howell Martin was born in 1867 and married Irvin or Ervine Adams in 1889 at Elbert. From at least 1900 to 1930 they farmed at Goshen and had eight children including three sons who may have continued the line.

- Allen T of 1871 married Texas Teasley at Elbert in 1891 and had four children including three sons. They farmed at McCurry, but Allen died at just 30. Texie, though, lived on to 1936 latterly living with daughter Faith at Shreveport, Louisiana where she worked as a clerk.

- Paul Easton was born in 1876 and married Mary Brown around 1897. They farmed initially at McCurry and had seven children but by 1910 were at Hartwell where Paul was a merchant in the grocery line. From 1920 onwards they were in Atlanta where Paul initially was selling candy, before turning to fertilizer.

- Mack Curtis was born at Hart in 1879 and married Sallie Duncan there in 1898 with whom he had three children, though son Hoke died in his second year. They farmed at McCurry.

- William Ottis was the last son in 1881. He too farmed at McCurry. He married Leila Duncan in 1899 and they had ten children, including six sons though two, at least, died young.

\section{LINE 3 - from Joshua Mewboorn c1730}

Joshua's line got off to a shaky start with only a single son in each of the two following generations to continue the line at Chowan. However, there was a considerable expansion through Charlton Augustus following his move to Tennessee via Alabama. 
Thomas Mewboorn 1688

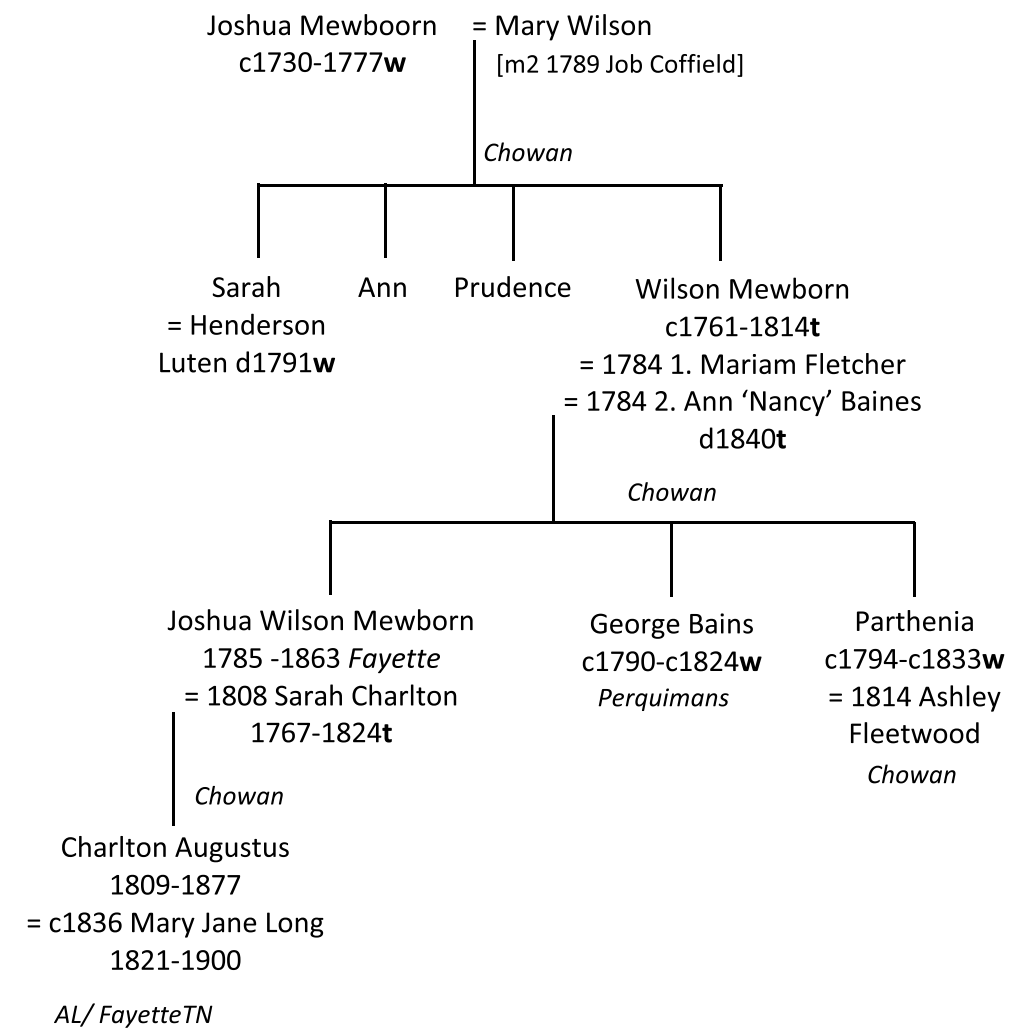

Figure 31. Descent from Joshua Mewboorn, c1730, generations 2-5.

Joshua is known to have left a will but there is no image available. Instead we have an index entry in the North Carolina Historical and Genealogical Register that gives:

"Newborn, Joshua (without date). Mrs Mary Newborn, daughter Sarah Luten, son Wilson, daughters Prudence and Ann Newborn."

There are no other records for Joshua.

Daughter Sarah was married, by the time Joshua made his will, to Henderson Luten of a prominent local family. Henderson died in 1791 and 'Willson Mewborn' is one of the witnesses to his will.

For Joshua's son, Wilson, we have first a record of a marriage in 1784 to a Mariam Fletcher. She is presumed to have died promptly since there is also a record of his marriage at Perquimans, NC in 1784 to Ann Bains. He then appears in the Tax List for 1795 at Capt. Howcott's District, Chowan (along with cousins Nicholas and William) where he had 100 acres. $^{53}$

There is no will for Wilson, but court papers on Ancestry.com show his son Joshua bound as administrator to his estate on the $13^{\text {th }}$ of June 1814. Other court papers of 1816 illustrate a plat allocating 45 acres each to Joshua, George and Parthenia Fleetwood. George never married and, in his will, bequeathed his plantation to Parthenia's eldest son (and gave 50 cents each to his mother and brother and a dollar to Ashley and Parthenia!).

Joshua Jr was administrator for his own wife's affairs in 1824 and was still at Chowan, with just his 8 slaves, in 1830. He then moved to Fayette, Tennessee where he appeared living with his son Charlton Augustus in 1840 . He was on his own in both the 1850 and 1860 censuses before his death and burial at Macon in 1863. No will is known. 
A letter written by CA in 1867 has, however, been posted online at https://www.genealogy.com/ftm/m/c/l/Gayle-Lane-Mcleod/WEBSITE-0001/ UHP-0087.html and makes fascinating reading (slightly edited):

Dec. 7, 1876

John H. Martin

Dear Nephew

...

I propose tonight to interest you in this letter by giving you an account of my origin and some incidents of life - I may never see you - nearly all my relatives by my mother's side are dead. My mother, whose maiden name was Sarah Charlton, was born 14 May 1767. My father, Joshua Newbern was born 20 Jany 1785 . My mother's first husband was George Bains; her second was William Gregory, by both of whom she had children. Wm Bond of Edenton whom I visited, was a son of Elizabeth Gregory, on the death of Gregory, mother married my father. He was a young man (23) and she a widow having a good home. He soon found owing to the disparity in their ages; and that she had children of considerable size, that they would not be apt to get along as man and wife should.

A friendly separation was agreed upon. He traveled out west and was, I think in Nashville, TN when news of my birth reached him. He returned, settled in about 4 miles of my mother. Their separation was final - my mother was a very industrious woman. My father sent me to school letting me remain with mother till I was 15 years old. She consented in Feb '24 for me to go to live with my father and she died 9th June 1824 soon after (in which Whittaker and Caroline were born).

I was regarded as a promising boy. I roughted it much - plowed, coon hunted, wrestled with boys - black and white - and was getting rather wild. In the providence of God, father consented in Feb '27 for me to go to Suffolk - dear Suffolk, VA to keep store for brother Lem here. (This must be Lem Bains who dies prior to 1832). I was thrown into, or had access to the best society. Here I recd my religious impressions. Here I listened to some of the best preachers I ever heard. I lived here 3 years, returned home and went to school eight months.

Dec 2, 1830 my father and myself started to Huntsville Ala. and returned April 1831. In May 1831, my father not ready to move, two young men and I left my native country and came to Madison Co., Ala. My father then followed with his negroes, some 20 or 25 in Dec. following. He came to me, found me teaching school.

About this time, I got in love with several young ladies - but was opposed some by my father. In Nov 1834, he bought a farm in this county. He and I moved to it March '35, I took hold of business plowing, hoeing, rolling logs, (Our) crop was laid by. In July visited some friends in Madison Co., Ala and on 18th Aug'35 I was married to Miss Mary Jane Long, which was highly approved by my father. In Dec 1837, I bought a farm in Madison, AL. I made six crops. In '42 I sold out - moved to my father's in Feb '43 and on 19th day of Dec, 1843, I bought the land on which I now live.

... my wife has been the mother of 16 children of whom 9 are living. She is my junior 12 years and is now in pretty good health. Our children are regarded as nice and promising. We have eighteen grandchildren. Our oldest son, Joseph, is at Memphis doing a good business as a dentist. Two next sons are very industrious farmers doing well. All three were in the army, acted their part well and came home safe excepting two being wounded. We now have with us 2 daughters, single, and two sons. My eldest daughter, 20, I am sorry to say will, I fear marry against my wishes. My other daughter, 12 years old is fine looking, both are pretty.

If your have any nice georgian's who wishes to visit Memphis, tell him to call and get acquainted. I have been much blessed in life - more in a pecuniary point of view than any of my mother's children. I perhaps have as much energy as any man of my age around. I keep out of debt and an regarded as very punctual. I own the rise of 1600 acres land. I have a good two story house 20 by $52 \mathrm{ft}$ double portico with an ell 34 long in the rear- cook room, pantry, gallery, porch and good cistern with a pump - good stables and barn attached, hip roofed gin house, Pratt's gin and Wright's patent press. Though industrious and attending to business I try to not forget my God to whom I have been trying to pray since 1827. I try to bow in prayer every day that comes. I feel that God takes care of me. Four of my children belong to the Methodist Church. Please do not think me bragging in anything here said. I wish you to learn who I am and all about me. I have to tell you.

Write. Yours in Love

C.A. Newborn

A fascinating insight to life at the time and into the life of Charlton Augustus. It also provides an explanation for the 1810 census where at Capt. Creecy's District there are entries for Wilson Mewborn, as we might expect, and also for Sarah Mewborn, but not for Joshua (though he appears in later censuses). With Sarah in 1810 there is a male under 10, presumably Charlton Augustus, and two other males 16-25 and a female under 10 - perhaps they were Gregory children mentioned in Charlton's letter.

Another record that needs some explanation is the 1830 census for Nancy A. Mewborn at Perquimans. It is only Wilson and his family that have a connection to Perquimans and Nancy A is said to be between 60 and 69 years old. That matches Wilson's widow Ann Baines, and Nancy is a common pet name for Ann. However, it leaves a question over who she was living with - a 20-29-year-old male and another 40-49 plus a 3039-year-old female. They cannot include any of her children.

Charlton Augustus 1809, L3.1.1.1: G5-G7 - Alabama and Tennessee

Charlton was born on the 28th of January 1809, presumably at Chowan and it seems likely that he is the 10-15-year-old appearing with his father in the 1820 census at Chowan. However, he is not enumerated with his father in 1830, when by his own account he would have been at Suffolk, VA. In 1840 he is at Madison, Alabama with his wife Mary Jane Long, an Alabama girl who he had married in 1835 (she being still 
thirteen, three weeks short of her fourteenth birthday). By 1843, however they had resettled at Fayette, Tennessee where his father had been in place since 1835 .

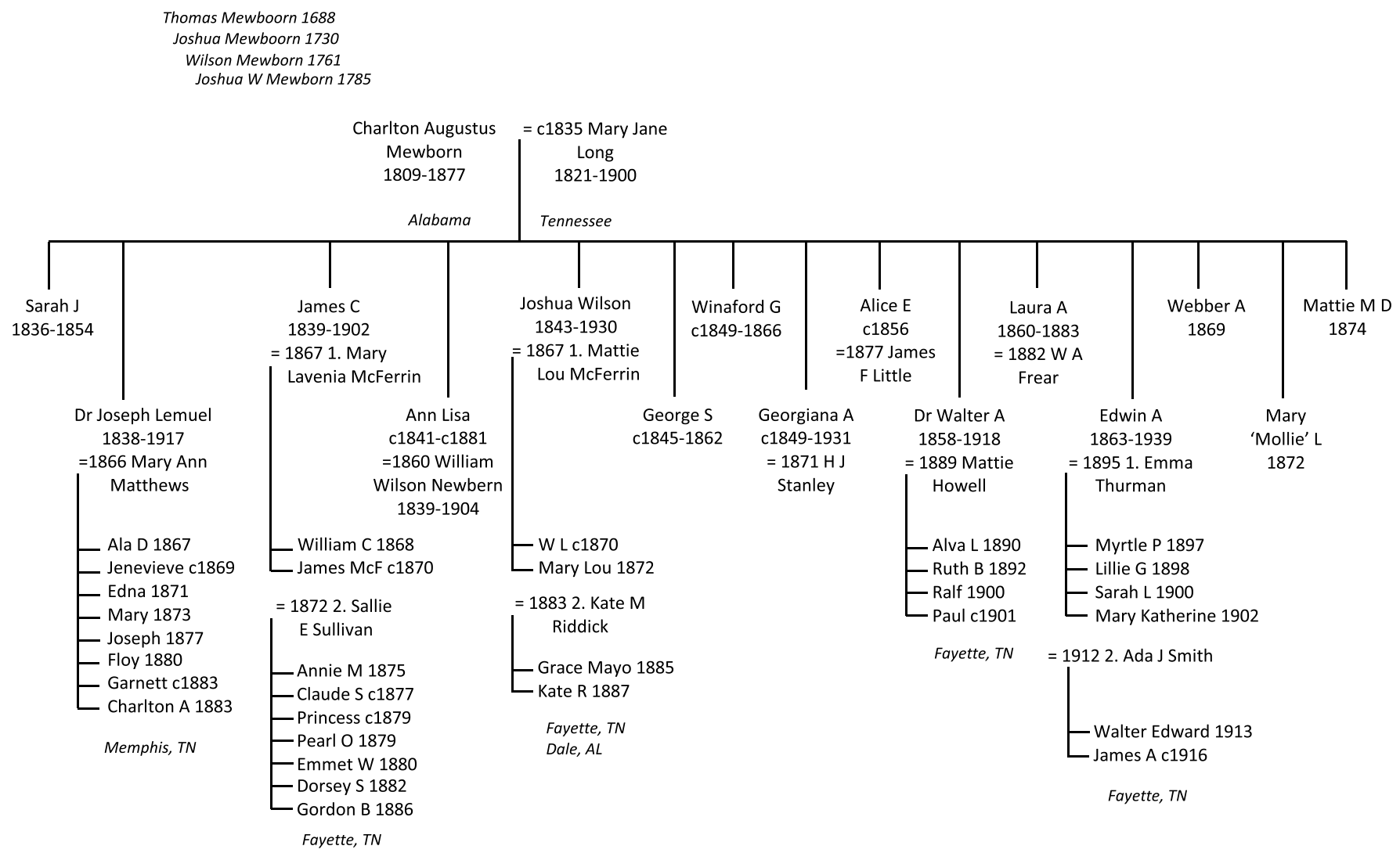

Figure 32. Descent from Charlton Augustus Mewborn, 1809, generations 5-7.

Charlton Augustus's first four children were born in Alabama and the birth dates show that they moved to Fayette around 1843. There they had eleven more children. Five sons perpetuated the line, two of them moving into the professional ranks as medical practitioners. His second daughter Anna Lisa demonstrated that there were still links across family lines by marrying William Wilson Newbern of the Nicholas line - both of the sixth generation - and farming with him at Madison, TN.

Of the five surviving sons:

- Dr Joseph Lemuel was born on the $3^{\text {rd }}$ of March 1838 at Huntsville, Alabama and moved into the professional classes becoming a dentist. He had moved with the family to Fayette, Tennessee and was married there in 1866 to Mary Ann Matthews. He was practising as a dentist at La Grange by 1870 but had moved to Memphis by 1880 where they remained and raised their eight children. Joseph died in 1917 and was buried at Forest Hill. Mary Ann lived on until 1934.

- James C stayed and farmed in Fayette. Born on the $16^{\text {th }}$ of October 1839 in Alabama he first married Mary Lavenia McFerrin in 1867 and had two sons by her before her death in 1870. He then married Sallie Sullivan at Marshal, Mississippi in 1872 and had another seven children at Fayette before his death in 1902 and burial at Macon cemetery.

- Joshua Wilson was the first of Charlton's children born in Tennessee in 1843 . He first married Mattie Lou McFerrin on the $2^{\text {nd }}$ of November 1867 - a double wedding with his brother James and a great coming together between the Mewborns and the McFerrins. They had two children before Mattie's death in 1874. In 1883 he married again and had two more children by Kate Riddick. Joshua was a mill owner as well as a farmer at Fayette. By 1900 the family had broken up. Joshua was living in Florida at Newberry, Alachua with three lodgers. Kate was nowhere to be seen in the census and their two daughters were living with their Riddick grandparents. Kate has not been found in the 1920 or 1930 censuses but was buried at the Macon Cemetery in 1932.

- Dr Walter Alva was born on the $8^{\text {th }}$ of August 1858 . He became a physician and was still at home with his widowed mother in 1880. However, in 1889 he married Mattie Howell at Woodruff, Arkansas and in 1900 they were still there, at Cache, with the first three of their 
four children. By that time, he was professing to be a merchant. By 1910 he was back to doctoring but was living with his family at Bandera in Texas. He died of stomach cancer at Macon back in Fayette in 1918. Later that year Mattie was in Los Angles with son Paul.

- Edwin Augustus was born on the $21^{\text {st }}$ of August 1863 at Fayette and remained there all his life farming and milling. He married Emma Thurman in 1895 and they had four children before her death in 1909. In 1912 he married Ada Smith and they had two more children. Edwin died and was buried at the Macon cemetery in 1939.

Note, that their mother, Mary Jane Long, if the records have been interpreted correctly, was an exceptional lady since she was about 53-years old when her last child was born.

\section{LINE 4 - from Moses Mewboorn c1732 - the most obscure}

Moses is important because there is a lack of clarity about descent from him. There is also a lack of appearance in records other than a note that he was a juror for a coroner's inquest at Bertie on the $17^{\text {th }}$ of March $1756 .{ }^{54}$ However, he left a will in 1767 which gives us a modest start.

Thomas Mewboorn 1688

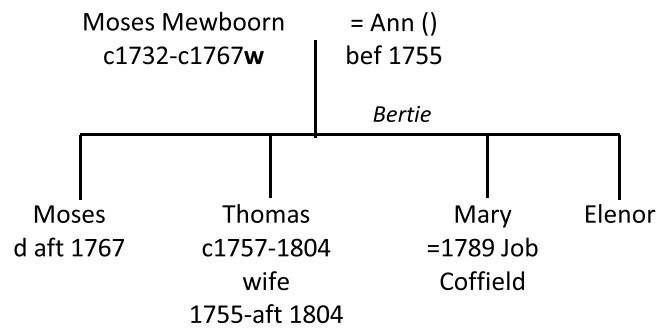

Figure 33. Descent from Moses Mewboorn, c1732, generations 2-3.

The main part of the will has been transcribed as follows:

“... The Thirtieth day of October 17 I Moses Mewboorn of North Carolina in the County of Bertie ... -

Imprimis I give and bequeath to my son Moses Mewboorn one shilling Sterling for particular reasons

Item I give and bequeath to my son Thomas Mewboorn all my Land \& Manner plantation whereon I now live to him his heirs \& assigns for ever

Item I give and bequeath to my Dear \& well beloved wife Ann Mewboorn the use of the aforesaid land \& plantation During her Natural life

I likewise give \& bequeath to her the one half of all my moveable Estate to her \& to her Disposal

I give and bequeath to my abovesaid son Thomas Mewboorn the Other half of all my moveable Estate to be Delivered to him when he comes to the age

of Twenty one years to him \& to his Disposal

Item I give to my daughters Mary \& Elenor each one Shilling Sterling

Item \& Lastly I do Constitute approve \& ordain my beloved Wife Ann Mewborn Executrix \& My Brother Thomas Mewborn My Friend William Hardy Executors of this my Last Will \& Testament..."

His wife Ann is identified, and two daughters, Mary and Elenor, as well as two sons - Moses jnr who was left a token sum, and Thomas who was the principal heritor, though under-age (so born after 1746). There is no trace subsequently of Moses jnr. Thomas appears in the March term of the Court in 1770 as a 13-year-old orphan of Moses placed under tuition of Job Hunter. ${ }^{55}$ We assume, therefore that he was born about 1757. There are, however, early census entries for Thomas at Bertie in 1787 and 1800.

There is also the record of a marriage at Chowan for Mary Newbern and Job Coffield in 1789. It is witnessed by Reuben Small of the family much married into In Nicholas's line.

In 1787 Thomas Newbern is recorded at Capt. Francis Pugh's Company in Bertie. The household consisted of one male between 21 and 60; one male under 20 or over 60 ; and 2 females.

There is one other record that may be relevant. A Thos. Newburn served in the Revolutionary War as a Private in Col. Thomas Clarke's Company of the Carolina Battalion. ${ }^{56}$ He enlisted on the $22^{\text {rd }}$ of April 1786 , served two and a half years, and was discharged on the $10^{\text {th }}$ of November 1778. The timing could well fit for Thomas 1757. However, it could also fit for Thomas the son of Nicholas in line 1. 
Thomas Newbern c1757, L4.2: G3-G5 - Bertie maybe to Georgia

Hard evidence for Thomas is slight, other than being named in his father's will and appearing as a 13-year-old orphan in 1770, giving us a 1757 approximate birth date. In the 1787 census at Bertie there is a household for Thomas Newbern consisting of one white male aged 21-60 (i.e. born between 1717 and 1766) and one white male under 20 (i.e. born between 1767 and 1787) or over 60 (though that is hardly an option), as well as two females of unspecified age.

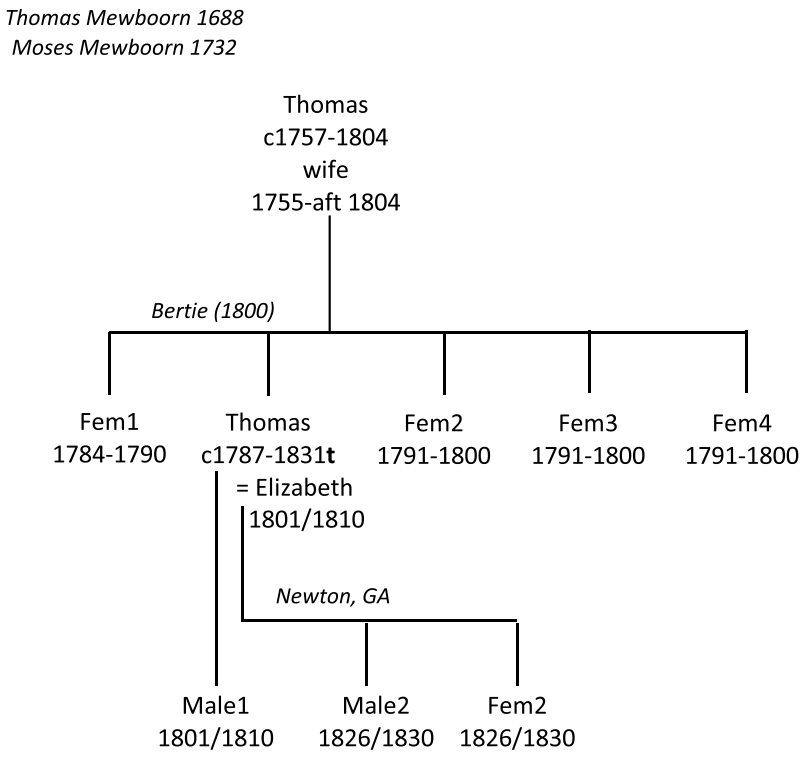

Figure 34. Descent from Thomas Mewborn, 1757, generations 3-5.

In 1800 there is a Bertie household for Thos Newben [sic], with one male between 10-15 (i.e. born 1785-1790) and a second aged 26-44 (i.e. born 1756-1774) - the latter presumably Thomas. There are also three females under 10, one 10-15, one 16-25 and one 45 and over. That suggests that Thomas's wife was a little older than he while the 16-25-year-old might equate to the second female recorded in 1787.

The young male was therefore born between 1785 and 1787 (if the enumerations are accurate). Likewise, Thomas was born between 1756-66, good timing to be the father of the younger one. Dates of 1786 and 1757 have been used as working assumptions for the two.

The records show little thereafter that is clear. There is a census record at Newton, Georgia, in 1830 for a Thomas Muborn said to have been born 1791-1800, perhaps not too far out to be the young male in Thomas's household from Bertie. There is also a Bond of Administration on the $7^{\text {th }}$ of March 1831 at Newton, GA to an Elizabeth Mewborn in respect of a Thomas Mewborn. ${ }^{57}$ It is quite possible that Thomas's son was a Thomas and that he migrated to Georgia. The 1830 census identifies an under five male and female who could be children of the young Thomas and a female aged between 20 and 30 who might take to be his wife Elizabeth. However, there is also another male in the 20-30 age bracket, too old to realistically be a son of the proposed Elizabeth but possibly a child of an earlier liaison. There is no identifiable sign of this family subsequently in Georgia.

This line ends unless proof can be found that Thomas's son did live and himself produced heirs in a location we can have convincing links to.

\section{LINE 5 - from George Mewboorn c1733 - the best studied}

This line, from George, is the most thoroughly studied. It has benefited hugely from the work of Ima Eula Mewborn (1912-2002) and her tracking down and painstaking transcription of a series of family bibles. 


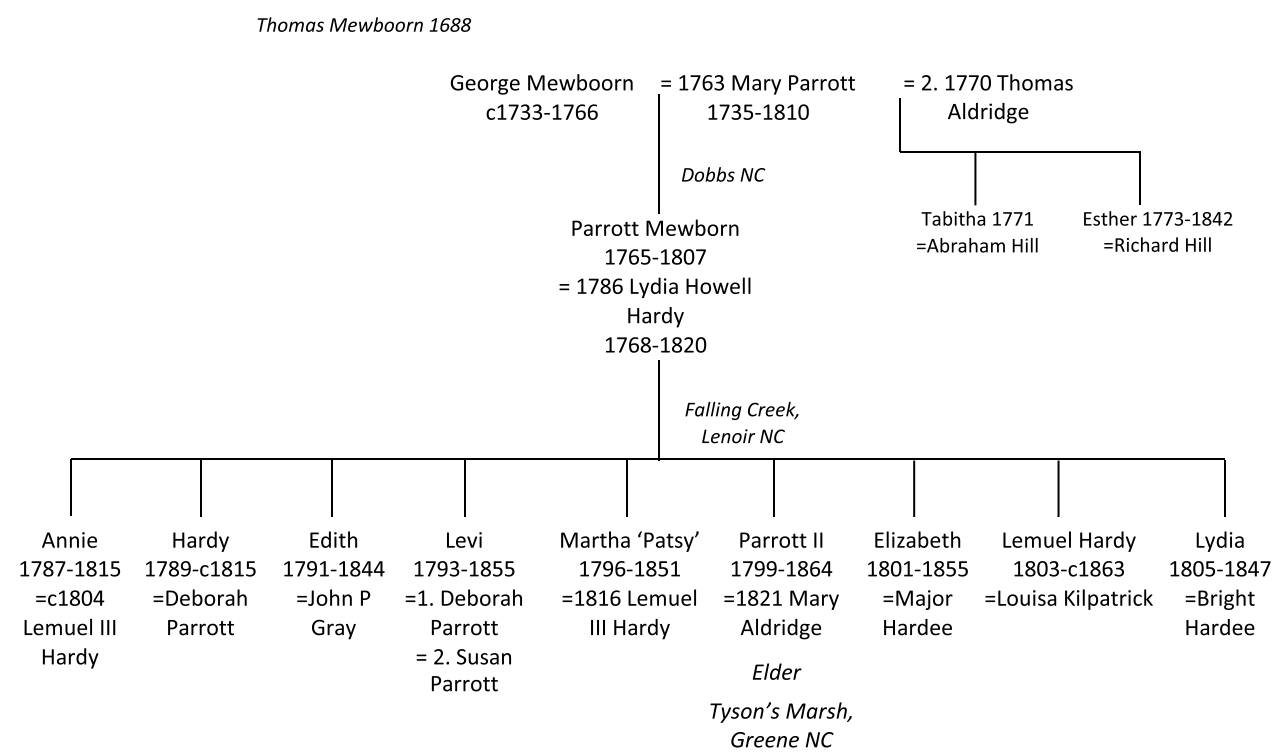

Figure 35. Descent from George Mewboorn, c1733, generations 2-4.

George appears in an early tax list for Bertie in 1757 but died before any Federal censuses. George and his younger brother John were the only brothers left as householders in Bertie by 1757. George's wife, Mary Parrott appears in another early tax list in 1769 after George's death, and by then she is at Dobbs. In 1770 Mary married Thomas Aldridge and it is known that some generations later, descendants from that marriage married again into the Mewborns. Continuing close links with the Parrott and Hardy family are also evident with grandchildren Hardy and Levi both marrying Parrots (Levi even marrying his brother's widow) and grandchildren Annie and Martha both marrying the same Lemuel Hardy.

Ima Eula Mewborn described the start of this line, as follows: ${ }^{58}$

In 1763 George Mewborn and his wife, Mary Parrott, sold their land to a Lockhart and moved to Dobbs County, on Falling Creek, near the present village of Institute in Lenoir County, NC. John Parrott, brother of Mary Parrott Mewborn, and his wife, Elizabeth Oxley, daughter of John and Olive Oxley, also moved to Dobbs County and settled on Falling Creek nearer to Kinston. It was important during this era to be on a creek as water mills for grinding wheat and corn were essential.

George Mewborn was a member of the old Bear Creek Church near LaGrange; this was a Baptist Church. Mary Parrott Mewborn was a member of The Church of England in Kinston until about 1770 when a new church was built at Contentnea northwest of Snow Hill, and she was a member here for convenience.

She and her second husband, Thomas Aldridge, lived in what is now Greene County. George Mewborn died in 1766 and left one child, a son, Parrott born 11 March 1765, named for his mother's family. Parrott was sent to Lemuel Hardy Jr. (1730-1797) and Mary Sutton family to be trained and educated with their children.

Lemuel Hardy Jr. was a first cousin of Mary Parrott Mewborn. Parrott Mewborn was with this family during the Revolutionary War. The young sons of Lemuel Hardy Jr., John and Sutton, and Parrott Mewborn were responsible for the home and farm during his absence of three years during this period, a great burden for these boys during this trying time. This old plantation was on Bear Creek near the present village of Jason, Greene County. This old home is described as a large house, first story brick and the second story clapboard.

Parrott Mewborn married Lydia Hardy 3 April 1786, born April 1768, died 1820/30, daughter of Benjamin Hardy (1732-1790) and his wife, Nancy Howell. Benjamin Hardy was a brother of the above Lemuel Hardy Jr. (1730-1797). To this union were born the following children: Annie born 726-1787 married Lemuel Hardy III; Hardy born 4-27-1789 married Deborah Parrott; Edith born 9-7-1791 married John Gray; Levi born 9-9-1793 married Deborah Parrott Mewborn, widow of his brother, Hardy, (1st); married Susan Matilda Parrott, (2nd); Martha (Patsy) born 2-6-1796 married Lemuel Hardy III, widower of her sister, Annie; Parrott Jr. born 1-1-1799 married Mary (Polly) Aldridge; Elizabeth born 3-5-1801 married Major Hardee; Lemuel Hardy born 1-26-1803 married Louisa Kilpatrick; and Lydia born 8-9-1805 married Bright Hardee. Parrott Mewborn Sr. returned to his father's old homeplace when he was married. He died in 1807 when his son, Parrott Jr., was in his ninth year. 


\section{Parrott I 1765, L5.1: G3-G5 - Lenoir, NC}

The first Parrott of 1765 lived at Falling Creek, Lenoir. Lenoir was created by the division of Dobbs in 1791 (the other part being Glasgow, later renamed Greene) at which point Dobbs vanished. Falling Creek runs off the Neuse river and is a border to the town of Kinston.

There is a strong religious focus in this line, and several of the men became preachers and elders of their churches. Partly in consequence, the families of Lenoir and Greene were great keepers of family bibles and much of what is known of them comes from such sources, and from the researches of Ima Eula Mewborn. Some of this material is held at the Archives of North Carolina and has been digitised and made available online. Notebooks of Ima Eula are also held at the Lenoir County Community College in Kinston. Another useful source is the blog at http:// www.bjhughes.org/ima.html.

Then there is the fine eulogy at http://freepages.rootsweb.com/ paday/genealogy/dobbers/ima.htm.

A Mewborn Family website at http://olddobbers.net is a remarkable source of information on the lines from George, well worth reading.

Parrott appeared in the 1790 census at Dobbs, prior to the partition. At that point there was only one young female with them presumably Annie. Parrott had four sons and from three of them there was an explosion of descendants. All told Parrott had 37 grandchildren, 14 of whom were sons to spread the name. To display that descent to the fifth generation it has been necessary to provide three separate images for the Parrot I descent.

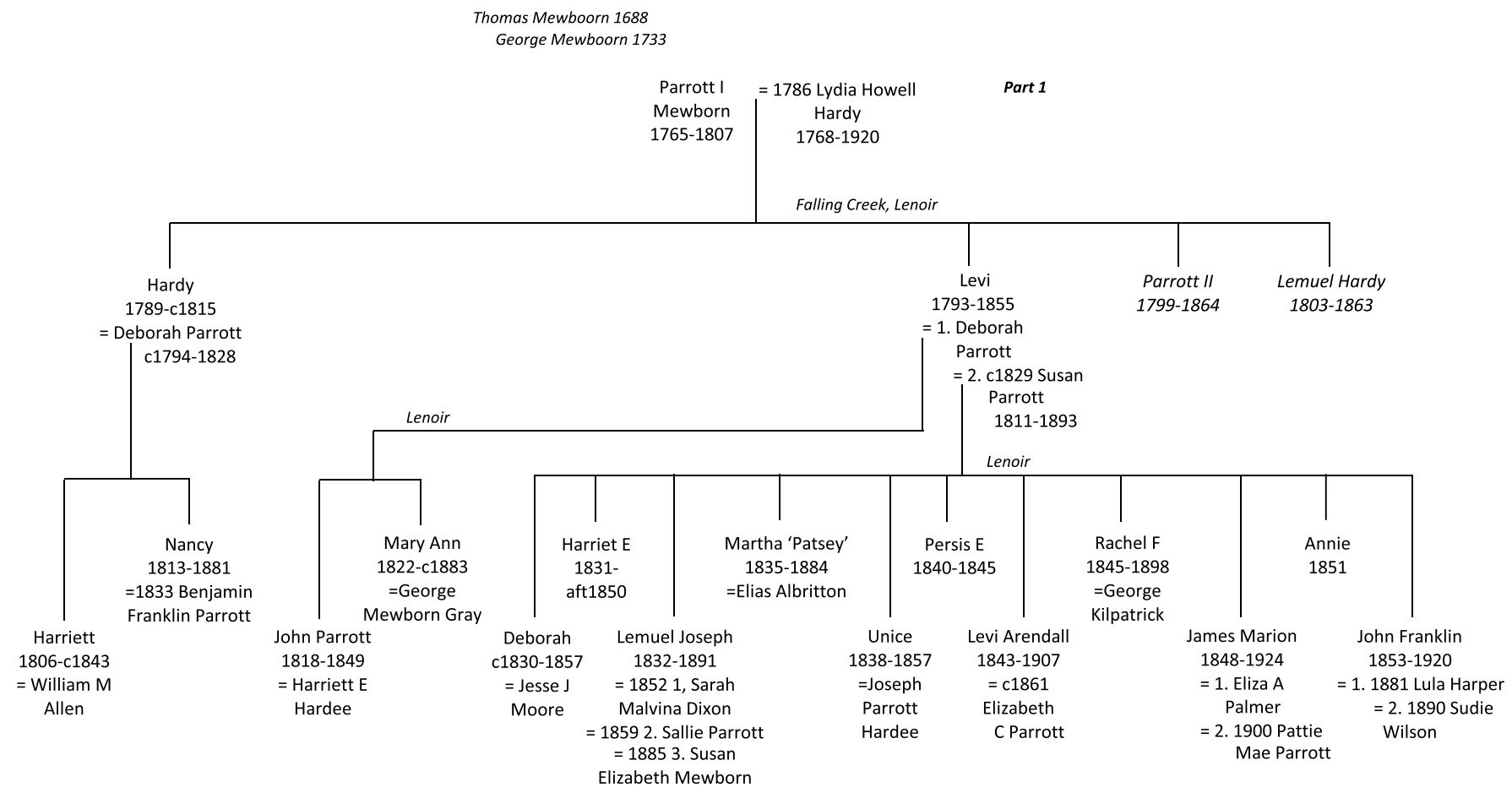

Figure 36. Descent from Parrott Mewborn, c1765, generations 3-5, part 1. 
Parrot's eldest son, Hardy died quite young and his widow, Deborah Parrott, was then married to the second son, Levi. Deborah was only in her early thirties when she died (after producing two more children following the two with Hardy), at which point Levi married her sister, Susan. The Mewborns and Parrotts were tightly bound.

Levi had five sons by the two Parrott sisters, but only the four by Susan carried the line forward.

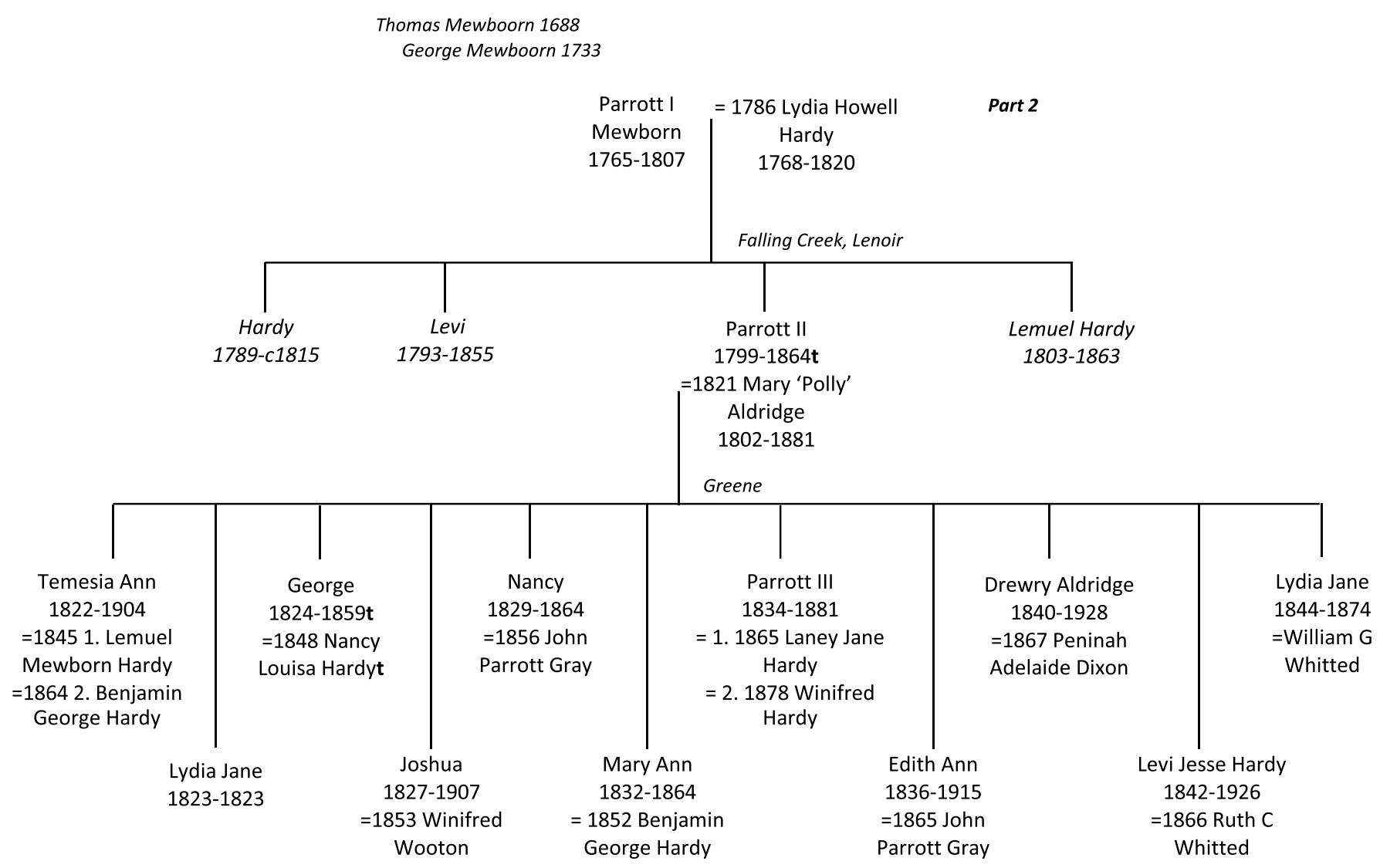

Figure 37. Descent from Parrott Mewborn, c1765, generations 3-5, part 2.

Parrott II lived in Greene County, the other part of the old Dobbs. His father died when he was just eight, so he was largely brought up by his mother. Greene, like Lenoir, was a tight-knit society and there was much intermarriage among a few families - Hardy, Gray and Whitted are notable on this tree, and they came around again in subsequent generations. There were five sons out of the eleven children to take the line forward. 


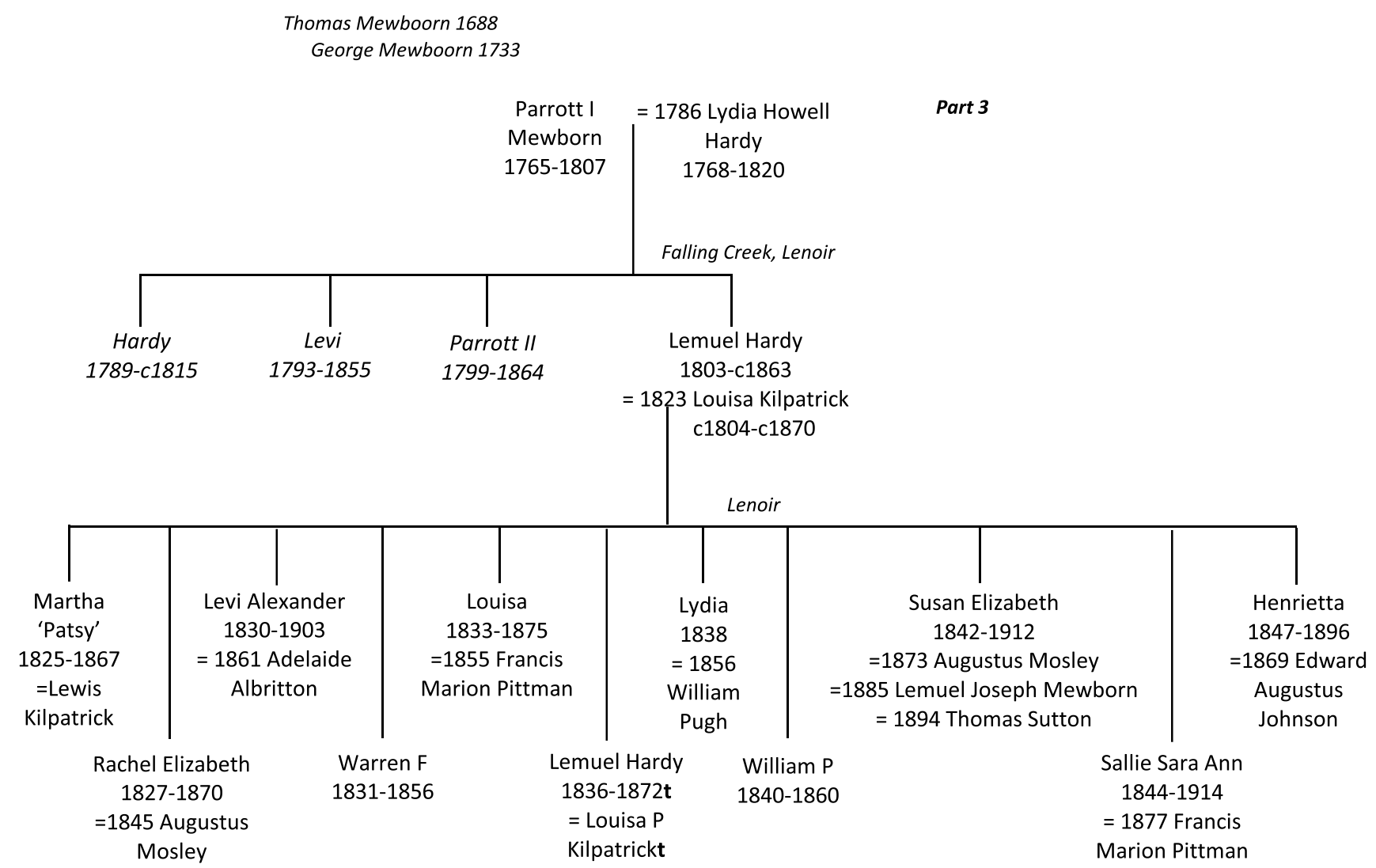

Figure 38. Descent from Parrott Mewborn, c1765, generations 3-5, part 3.

Lemuel Hardy was just five when his father died. He remained at Lenoir. He married into the Kilpatrick family as did two of his children, leading to the genealogically confusing situation where two generations of Lemuel Hardy Mewborns married Louisa Kilpatricks!

Lemuel Joseph 1832, L5.1.2.2: G5-G7 - Lenoir, NC

Lemuel Joseph was born on the $8^{\text {th }}$ of September 1832 at Lenoir. He achieved three marriages including, quite remarkably, one to a Parrott and one to a Mewborn. He farmed at Lenoir, initially at Kinston and later at Vance. He was buried at Westview cemetery in 1891. 


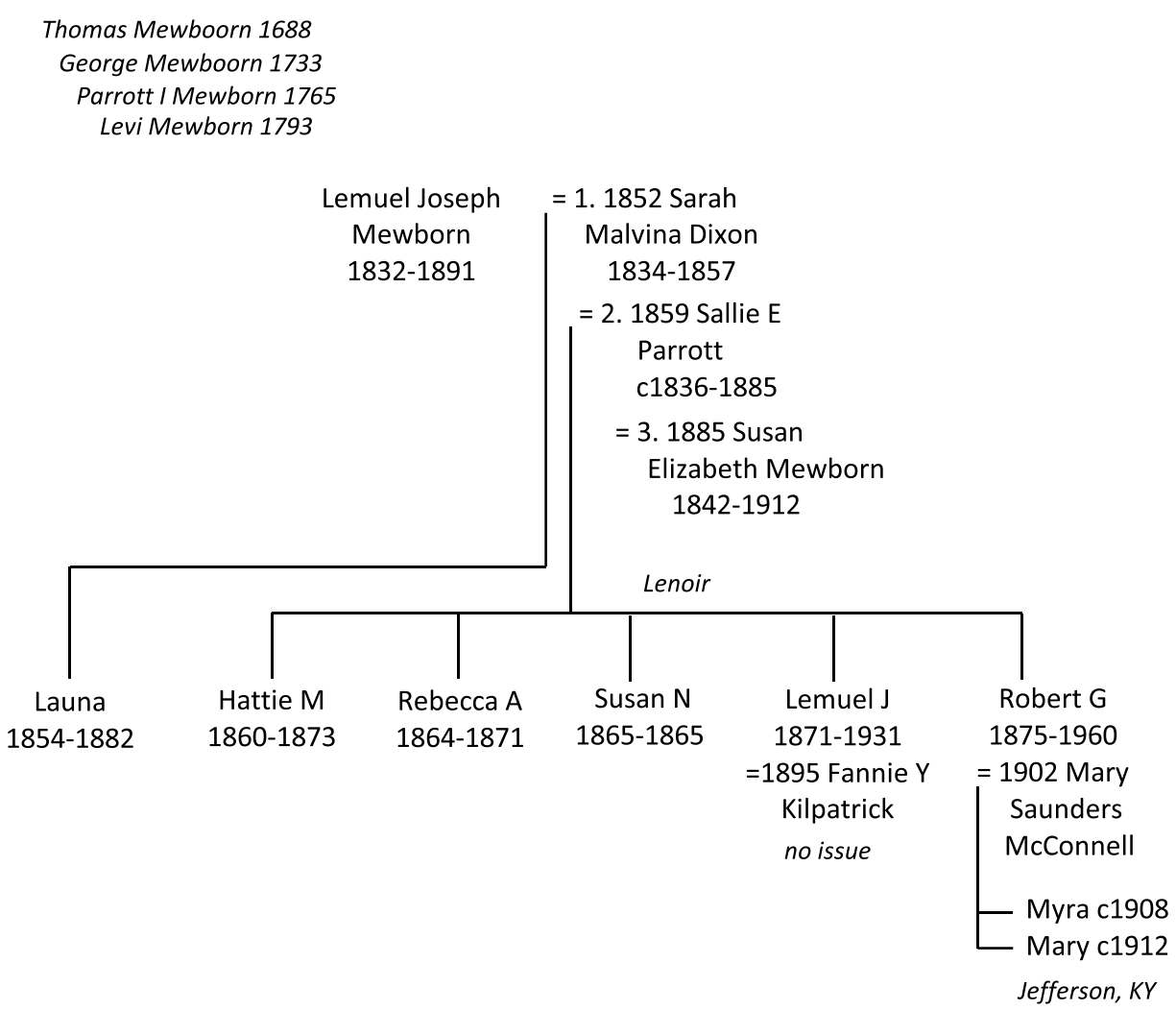

Figure 39. Descent from Lemuel Joseph Mewborn, 1832, generations 5-7.

Lemuel had two sons by Sallie Parrott:

- Lemuel J. He became a printer, farmer and merchant banker and by 1930 was bank president at Kinston. There were no children from his marriage to Fannie Kilpatrick.

- Robert Graham, the last of Lemuel's children in 1875 was also a business-minded man. By 1900 he was a chemist living at Brookland in Virginia. He moved to Kentucky and married Mary McConnell in 1902 and by 1910 was chemist in a tobacco company and living at Deer Park, Jefferson, KY. By 1930 they were at 99 Highway 66 in Bernalillo, New Mexico by which time Robert was president of a tobacco company. They ended up in Albuquerque where he was buried in 1960. There were no sons, so the name did not continue from this point.

Levi Arundell 1843, L5.1.2.3: G5-G7 - Lenoir, NC

Levi was born at Kinston on the $8^{\text {th }}$ of March 1843 and remained farming at Lenoir for the rest of his life, latterly at Vance. Family ties were close, and he too married a Parrott and had six children. 


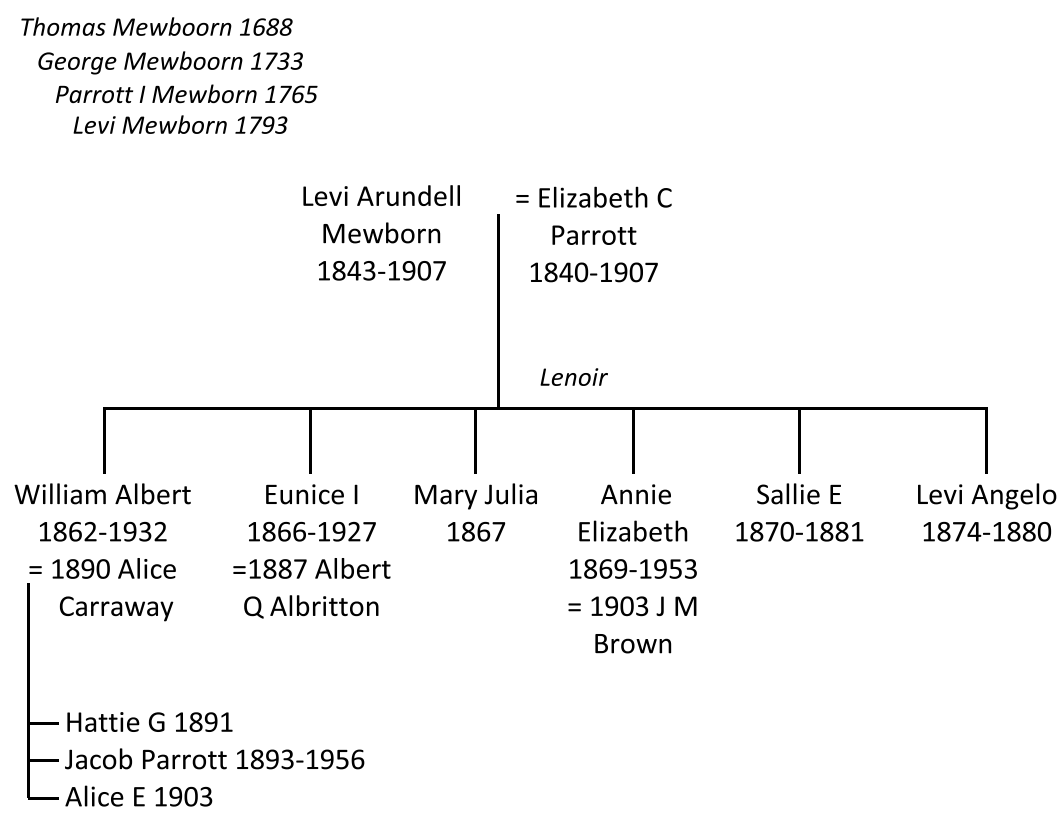

Figure 40. Descent from Levi Arundell Mewborn, 1843, generations 5-7.

There were two sons:

- William Albert broke away from the land and became assistant superintendent at a life assurance agency in Wilmington, NC. His son Jacob had at least two sons so the line may continue from there.

- Levi Angelo died young.

James Marion 1848, L5.1.2.4: G5-G7 - Lenoir, NC

James was born at Lenoir in 1848. He farmed first at Kinston, after his marriage to Eliza Palmer, then at Vance. He and Eliza had ten children before her death in 1899. On Xmas day 1900 he married Pattie Mae Parrott and had three more children by her at Kinston. James was buried at Mapleview Cemetery, Kinston in 1924.

James gave all his children a Mewborne spelling for their surname - a fairly rare example of that added grandeur.

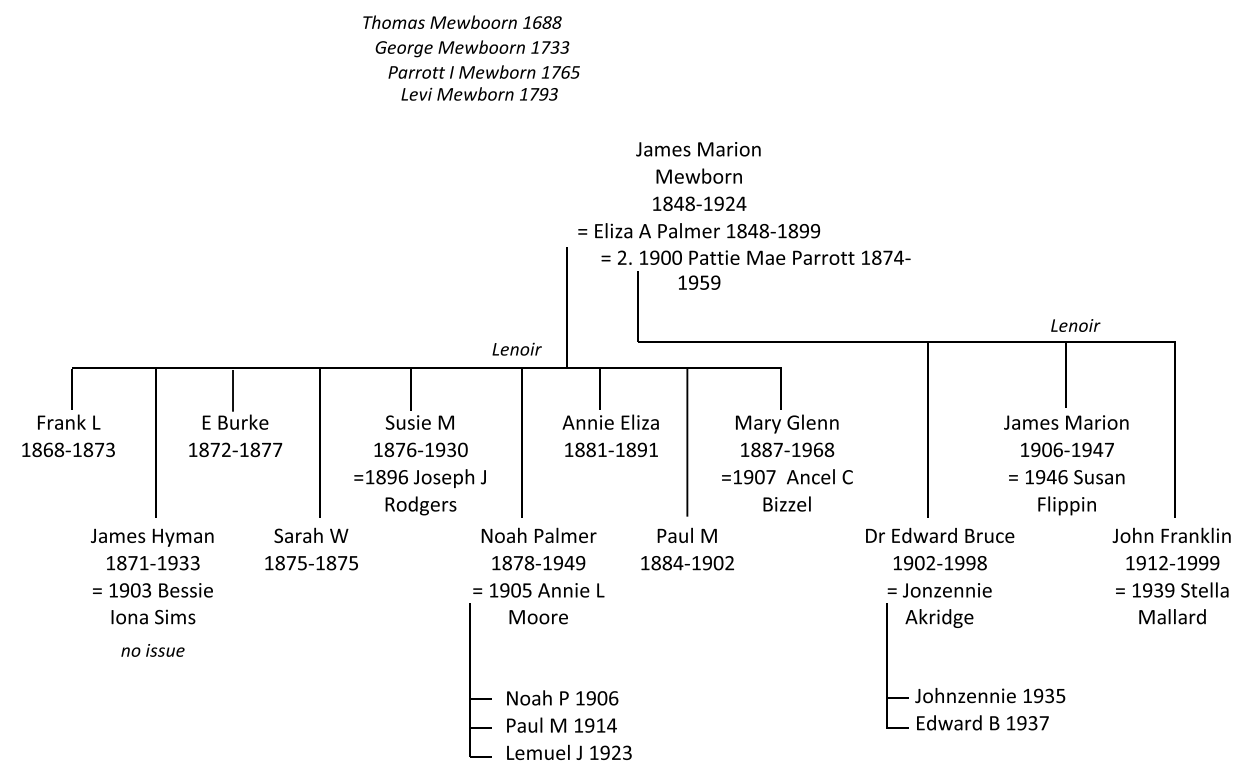

Figure 41. Descent from James Marion Mewborn, 1848, generations 5-7. 
Of the sons from the first marriage only Noah had children:

- Noah P died at eighteen.

- Paul Marion was not yet three when he died.

- Lemuel J was swept up into World War 2 and died in 1945 at Margraten in Holland.

There were three sons from the second marriage:

- Edward Bruce became a doctor qualified at the University of North Carolina. In the 1930 census he was working at the famous Johns Hopkins Hospital in Baltimore then in 1840 was in practise at Hampton, Virginia where he remained. His son also became a doctor practising at San Antonio, Texas and the line continued from him via six sons.

- James Marion became a lawyer and insurance adjuster. He is believed to have married Susan Flippin around 1946, a year or so before his death. No record of the marriage has been found online and there is no sign of any children.

- John Franklin was born in 1912. He became a bookkeeper and in 1939 married Stella Mallard at Lenoir. They later lived at Greenville and are not known to have had children. In 1957 John was acting postmaster for Kinston.

John Franklin 1853, L5.1.2.5: G5-G7 - Lenoir, NC

John Franklin was born at Lenoir on the $13^{\text {th }}$ of January 1853 and given the Mewborne spelling. He was a clerk in 1880 before his marriage in 1881 to Lula Keziah Harper. By 1900 he was a cotton buyer, and by 1920 a cotton merchant. 1910 saw him living at Orangeburg, South Carolina with his second wife Sudie Wilson and their youngest child was born there in 1908. All the children, apart from the youngest, remained in South Carolina.

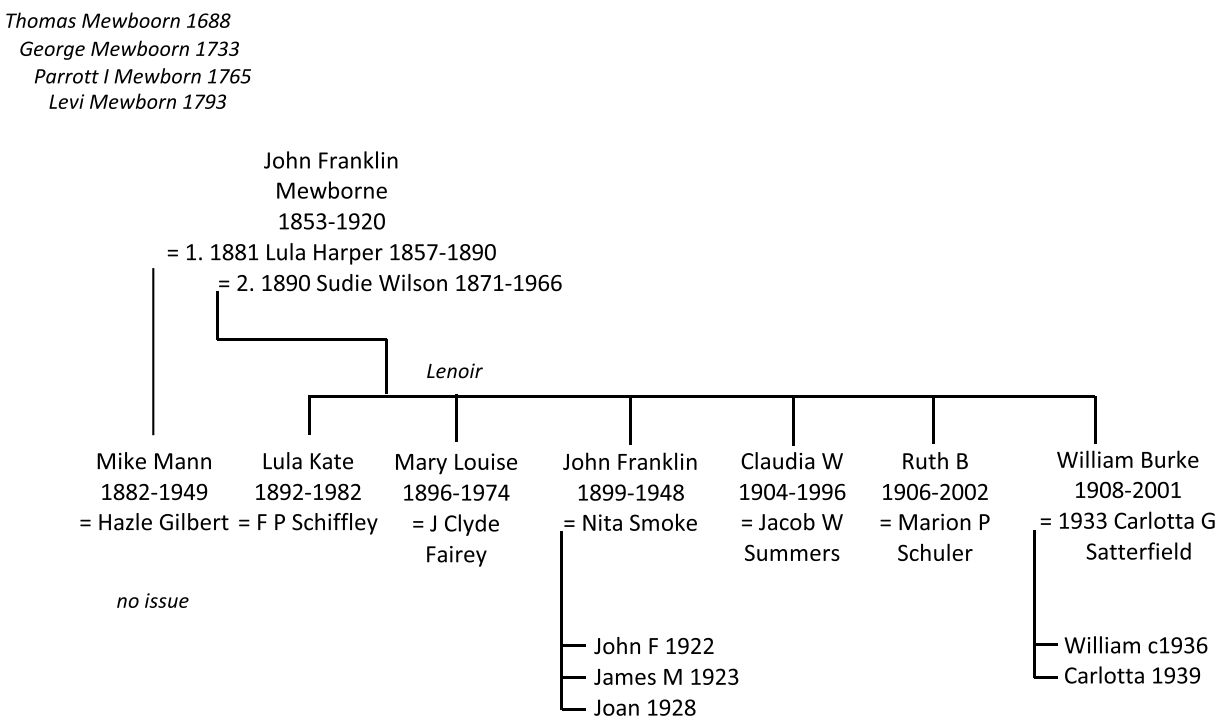

Figure 42. Descent from John Franklin Mewborne, 1853, generations 5-7.

There was just one child from the first marriage:

- Mike Mann was a travelling salesman in 1910. By 1920 he had married Hazle Gilbert and become a bookkeeper then later was a merchandise broker in Charleston. He had no children.

There were two sons from the second marriage and each married and had children:

- John Franklin Jr joined his father in the cotton business but later ran his own insurance agency. There were two sons from his marriage to Nita Smoak. Young John died in infancy; James was left to carry on the line.

- William Burke moved back to North Carolina. He married Carlotta Satterfield at Durham in 1933 and by 1940 was with her at Roxboro and working as a lumberman. He lived there until his death in 2001 and was buried at St Mark's Episcopal Church Columbarium. He had a son William Burke Jr to carry on the line. 
George 1824, L5.1.3.1: G5-G7 - Greene, NC

George was the eldest son of Parrott II. He ended up in Greene, the neighbouring county to Lenoir, both counties having originally been part of Dobbs.

George farmed at Greene but died at just 35. However, he had married Nancy Louisa Hardy in 1848 and lived long enough to appear in the 1850 census, with the names to confirm identity.

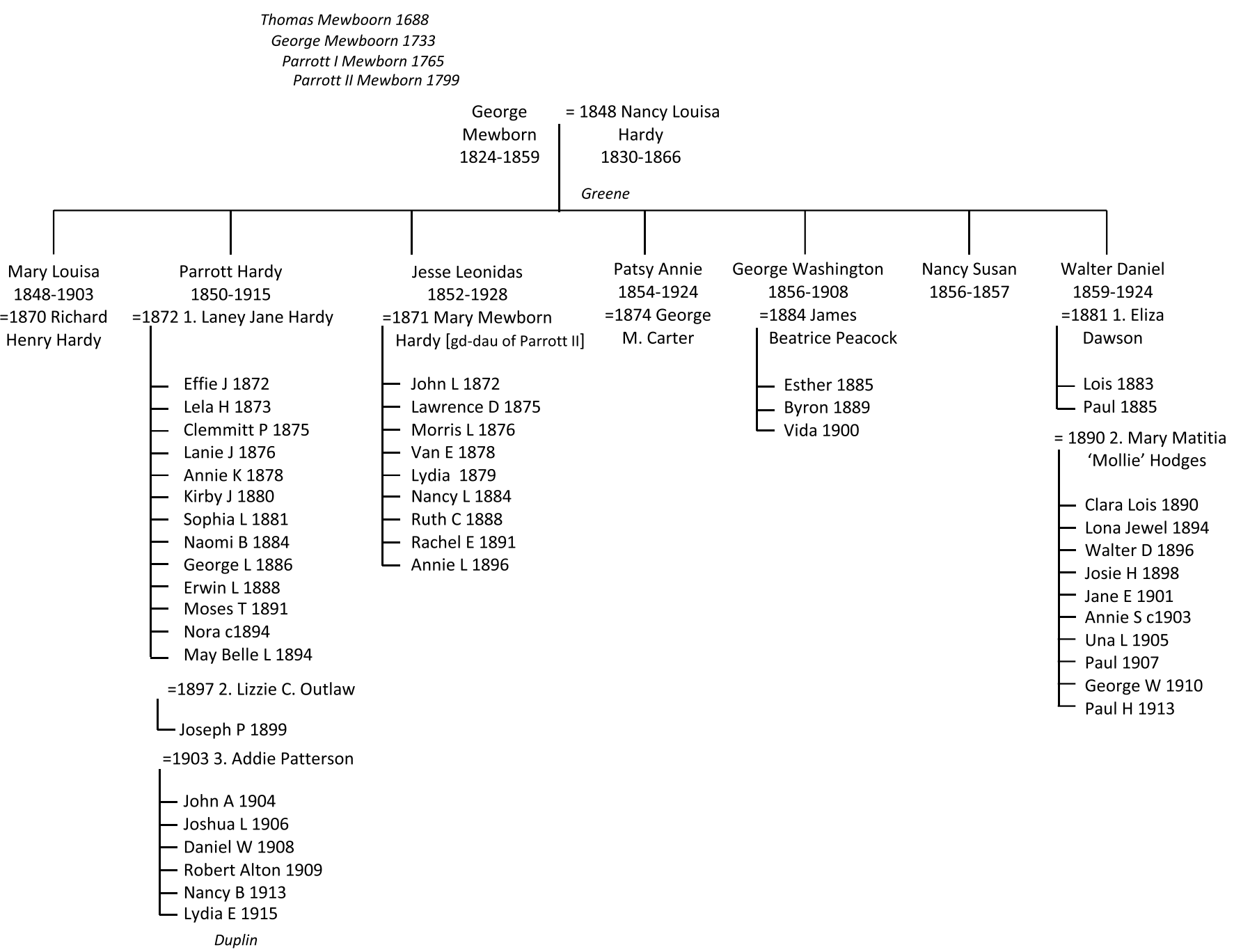

Figure 43. Descent from George Mewborn, 1824, generations 5-7.

In the eleven years George and Nancy were together, they had seven children, including four sons to continue the line:

- Parrott Hardy was born at Greene on the $29^{\text {th }}$ of August 1850 , too late to catch the census. He was farming at Snow Hill in 1870 after his parents' deaths and made his first marriage with Laney Jane Hardy in 1872. They had 13 children before her death in 1897. Soon after Laney Jane's death, Parrott married Elizabeth Outlaw and moved to farming at Albertson in Duplin County. They had one son before Elizabeth's death in 1902. A third marriage took place around 1903 with Addie Patterson. Addie was 25-years younger than Parrott and eventually outlived him by 40 years. They, however, had another six children. Of the 21 children there were ten sons though three died young.

- Jesse Leonidas was born at Greene in 1852 and farmed at Snow Hill and later at Shine. By 1920 he had moved to New Hope in Wayne County. He married Mary Mewborn Hardy in 1871 and had nine children including four sons and the line went on from there.

- George Washington was born in 1856 at Greene and married the slightly unusually named James Beatrice Peacock at Lenoir in 1884. George himself was a little unusual as he became a teacher and Principal of Rock Ridge High. He is elusive in censuses but was buried in the Mewborn Cemetery at Jason, Greene. His only son died in infancy. 
- Walter Daniel was born at Greene in 1859. By 1880 he was farming at Snow Hill but by 1900 was at Jason, where he remained. He died in 1924 and lies in the Mewborn Cemetery. He married Eliza Dawson at Lenoir in 1881 and had two children at Greene before her death in 1887. A second marriage to Mollie Hodges at Greene in 1890 led to another ten children. There were five sons in all, so the line continued with them.

Joshua 1827, L5.1.3.2: G5-G7 - Lenoir, NC

Joshua was born to Parrott II on the $18^{\text {th }}$ of April 1827 at Greene and is named with his parents in the 1850 census there. He married Winifred Wooten at Greene in 1853 and had eight children by her. By 1860 they were farming at Tyson's Marsh; by 1880 they were at Snow Hill; and by 1900 were at Jason - by which time only three of the children were still living. Joshua died on the $29^{\text {th }}$ of January 1907 and was buried at the Mewborn Cemetery. Winifred had died four years earlier.

Joshua served in Co. F, $3^{\text {rd }}$ Light Artillery Battery, North Carolina Regiment during the Civil War. His three younger brothers also served.

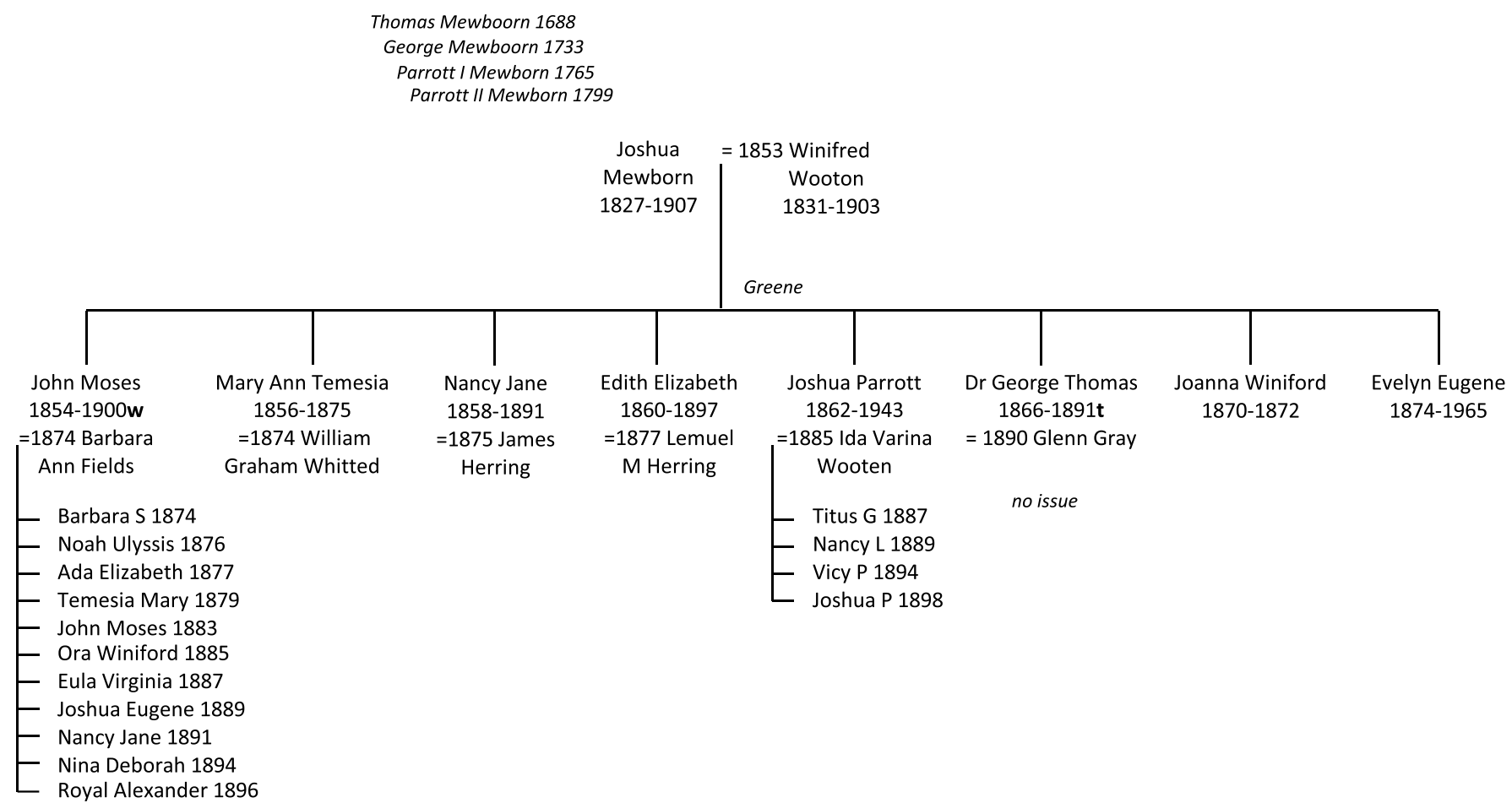

Figure 44. Descent from Joshua Mewborn, 1827, generations 5-7.

There were three sons.

- John Moses was born on the $25^{\text {th }}$ of July 1854. He married Barbara Ann Fields in January 1874 and had eleven children by her. In 1880 they were at Snow Hill and in 1900 at Jason where, in April, he died naming his ten living children in his will. The line may continue from them.

- Joshua Parrott was born on the $25^{\text {th }}$ of September 1862 at Greene where he farmed, married Ida Wooten and had four children. In 1940 he was living with his eldest son, Titus and his family at Greene. The youngest son Joshua died in 1914.

- George Thomas became a doctor but died aged just 25. Court records indicate that he had no children.

Parrott III 1834, L5.1.3.3: G5-G7 - Greene, NC

Parrott III was born on Thursday the $21^{\text {st }}$ of August 1834 at Jason. He enlisted for the Civil War on the $19^{\text {th }}$ of June 1863 and served in the $30^{\text {th }}$ Infantry Regiment. He was an ordained Primitive Baptist minister as well as a farmer and lived at Snow Hill in Greene and latterly at LaGrange in Lenoir. Parrott married Laney Jane Hardy of Tyson's Marsh, daughter of William E and Rosa Edwards, and had five children before her early death in 1876. Within two years he married Winifred Hardy, a younger sister of Laney Jane. Winifred had a daughter but died the same year, perhaps as a result of birth complications. 


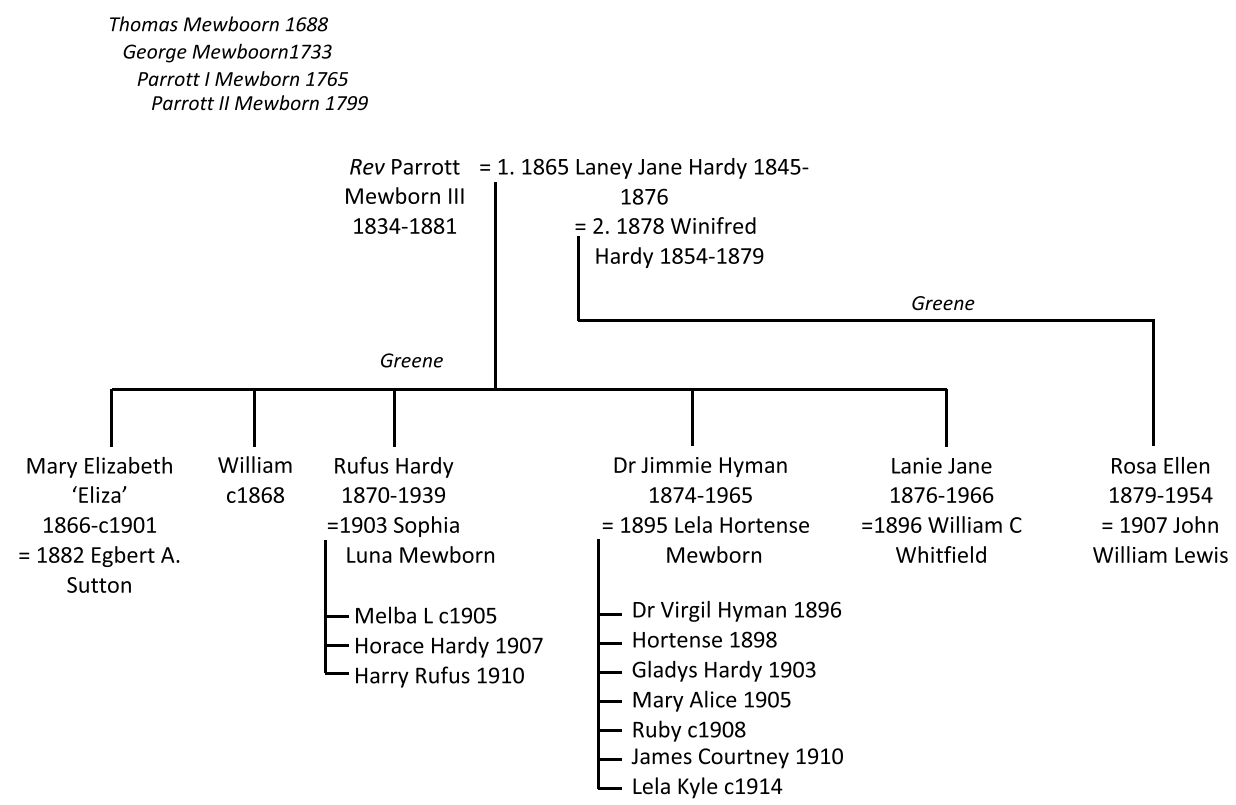

Figure 45. Descent from Parrott Mewborn, 1834, generations 5-7.

Two sons from the first marriage grew to adulthood:

- Rufus Hardy was born in 1830. He married Sophia Luna Mewborn and lived at Mosley Hall, Lenoir. The records show that the marriage took place on the $26^{\text {th }}$ of August 1903. However, the relationship may have flourished earlier since in the 1900 census Rufus was living at Mosley Hall with his brother Jimmie, a jeweller, Jimmie's wife Lela Hortense Mewborn and her sister - Sophia. Rufus and Sophia were both listed as single at that point. Sophia and Lela were daughters of Parrott Hardy Mewborn (1850-1915) and his wife, another Laney Jane Hardy (1854-1897). The Mewborn/Hardy links were considerable at this point. The brothers and their wives were cousins. Rufus had a varied career ranging from barroom clerk through farmer to tax lister. The line is believed to have continued through second son Harry Rufus (Rufus Harry) in Virginia.

- James Hyman, known as Jimmie, was born in 1874 and attended Guilford Quaker College (1888-89) in Greensboro. He married Lela Mewborn at Lenoir in 1895. They had seven children including two sons, Dr Virgil and James, to potentially continue the line. He established a successful jewellery business at Kinston as Mewborn \& Turner and in the 1950s also practiced as an optometrist. At his burial in Westview Cemetery his memorial describes him as Dr Jimmie.

Drewry Aldridge 1840, L5.1.3.4: G5-G7 - Greene, NC

Drewry Aldridge was born on the $14^{\text {th }}$ of June 1840 . He served in the $47^{\text {th }}$ Infantry Regiment during the Civil War and became a prisoner of war. Later, like his elder brother, he became an ordained Primitive Baptist minister. He married Peninah Dixon in 1867 and had eight children by her. They farmed first at White Oak, Carteret then, from at least 1900 onwards, at Carrs in Greene County. 


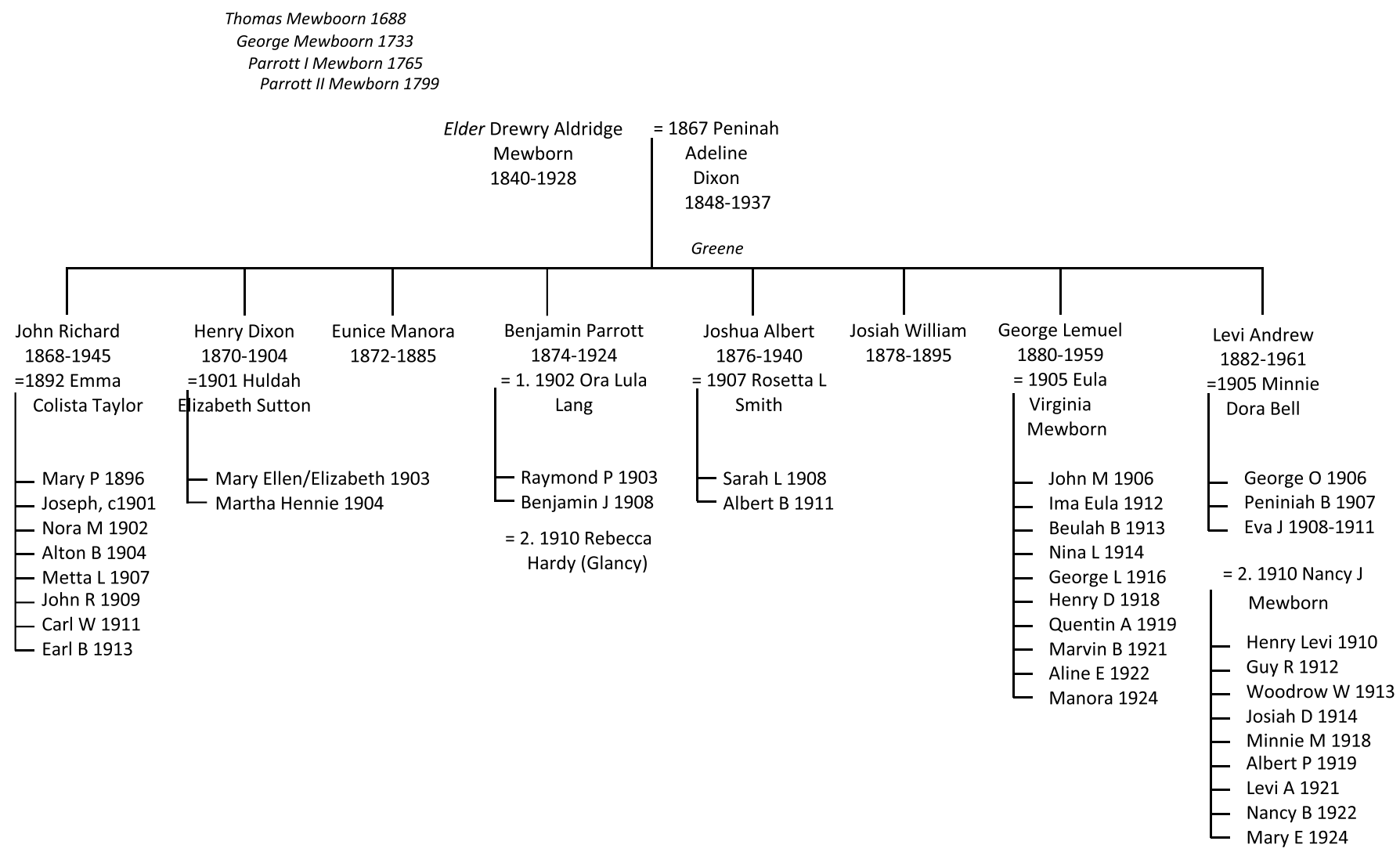

Figure 46. Descent from Drewry Aldridge Mewborn, 1840, generations 5-7.

Seven of the eight children were sons:

- John Richard was born on the $4^{\text {th }}$ of April 1868. He married Emma Colista Taylor at Greene in 1892 and they farmed at Bull Head, Greene and had eight children, including five sons to potentially continue the name. He was buried at the Mewborn Church Cemetery at Snow Hill in 1945.

- Henry Dixon was born on the $6^{\text {th }}$ of April 1870 and married Huldah Elizabeth Sutton at Lenoir in 1901. They had two daughters before Henry's untimely death in 1904 at Olds township.

- Benjamin Parrott was born on the $3^{\text {rd }}$ of April 1874 at Carrs township. He married Lula Lang in 1902 and had two sons by her. They divorced, and in 1910 he married Rebecca Hardy at Rockingham. There were no children from that second marriage.

- Joshua Albert was born on the $13^{\text {th }}$ of March 1876. He married Rosetta Smith at Greene in 1907 and they settled to banking and farming at Farmville, Pitt. He was ultimately buried at Pitt in 1940 at Forest Hills Cemetery. Joshua and Rosetta had two children, with son Albert to continue the line.

- Josiah William died at just seventeen.

- George Lemuel was born on the $10^{\text {th }}$ of August 1880 at Greene and in 1905 married his cousin Eula Virginia Mewborn at Carteret. They farmed at Greene (variously at Carrs, Snow Hill and Bull Head) and had ten children including five sons. Ima Eula Mewborn, the distinguished family historian, was their second child.

- Levi Andrew was born on the $28^{\text {th }}$ of August 1882 at Greene and farmed at Carrs. He married firstly Minnie Dora Bell in 1905 at Carteret and they had three children, including one son, before Minnie's death in 1908. His second marriage was to a cousin, Nancy Jane Mewborn, in 1910 and they went on to have another nine children including another six sons. However, three died in infancy and only Joe and Levi may have continued the line.

Levi Jesse Hardy 1842, L5.1.3.5: G5-G7 - Greene, NC

Levi was born on the $31^{\text {st }}$ of August 1842, the tenth child of Parrott II, and married Ruth Whitted at Institute in 1866 . They had eleven children, including four sons who lived into adulthood. He was a farmer, miller and merchant as well as a greatly respected public figure. 
Levi served in the $61^{\text {st }}$ Infantry Regiment during the Civil War. Later in life he became much involved in public affairs and Ima Eula noted that he "served in the Legislature in 1913 and 1924, he was a Justice of the Peace for twenty years, also a magistrate for several years".

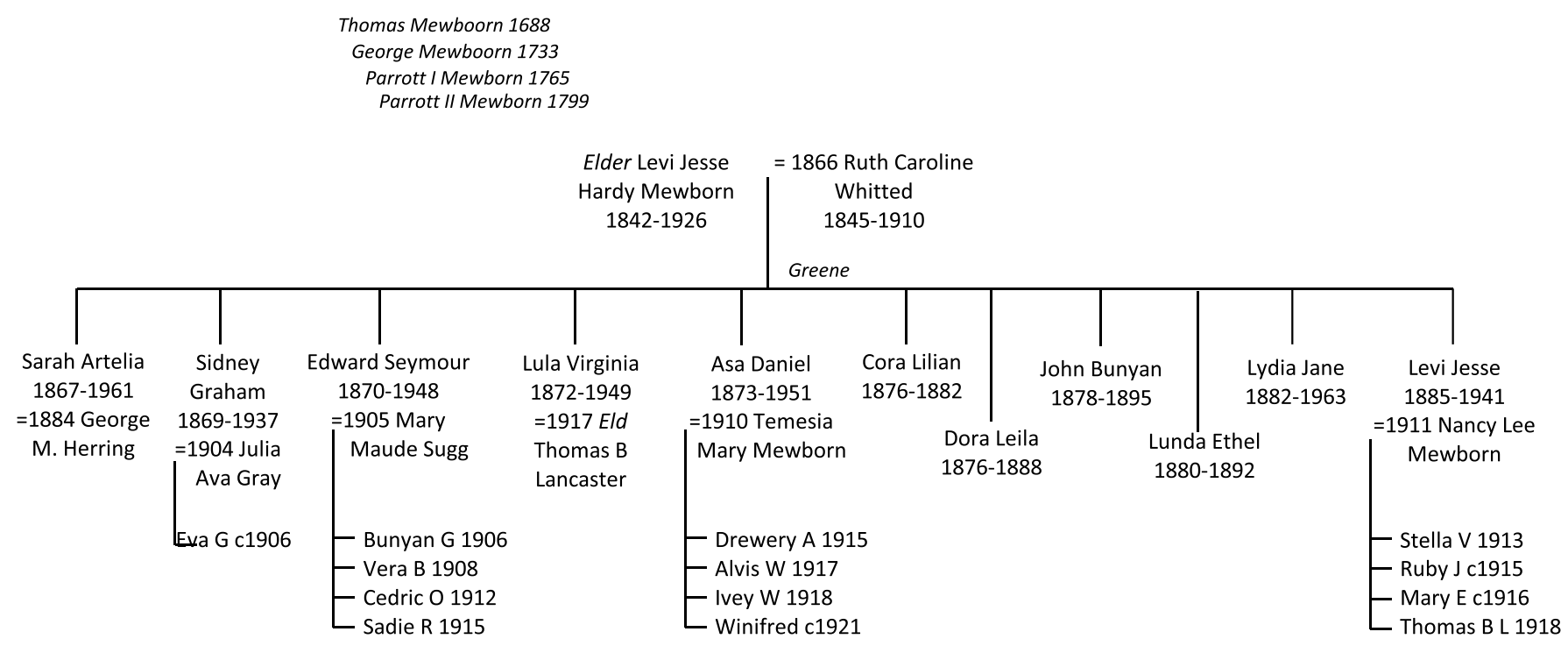

Figure 47. Descent from Levi Jesse Hardy Mewborn, 1842, generations 5-7.

Four sons were married:

- Sidney Graham was born on the $18^{\text {th }}$ of November 1869 and became a lawyer. He married a cousin, Julia Gray, in 1904 at Lenoir. They lived at Wilson and had one daughter. By 1910 Sidney was the clerk of court but by 1920 was president of the local bank.

- Edward Seymour was born on the $16^{\text {th }}$ of July 1870 at Greene. He married a cousin, Mary Maude Sugg at Greene in 1905 and they settled at Mosely Hall where he had a business as a grocery merchant. They had four children. The first died in infancy and there is no evidence that the line continued through Cedric.

- Asa Daniel was born on the $10^{\text {th }}$ of December 1873 and he too married a cousin, Temesia Mary Mewborn, at Greene in 1910. They farmed at Jason and had four children including three sons so the line may have continued.

- Levi Jesse was born on the $18^{\text {th }}$ of July 1885 and continued the tradition by marrying a cousin, Nancy Lee Mewborn at Greene in 1911. They settled first at Tarboro in Edgecombe where Levi was a grist miller. They then moved to Princeville where again Levi was a grist miller but by 1940, he had become a merchant. Levi died in 1941 and was buried at Tarboro in Greenwood Cemetery. Nancy, though, lived on for another forty years, dying at Edgecombe when 96. They had four children including a son to continue the line.

Levi Alexander 1830, L5.1.4.1: G5-G7 - Lenoir, NC

This takes us to the descendants of the last of the first Parrott's sons, Lemuel Hardy 1803. Four of his eleven children were sons, and descendants from two of them are known. Warren Francis (1831) died at eighteen and William Parrott (1840) died in 1860. Levi Alexander and Lemuel Hardy carried on the line.

Levi was born on the $23^{\text {rd }}$ of October 1830 at Lenoir and married Mary Kilpatrick at Pitt in 1856 . Sixteen months later she was dead and by the census of 1860 he was farming with his father at Contentnea. He married Adelaide Albritton in August 1861 then, on the $30^{\text {th }}$ of June 1862 , he enlisted to the Confederate army in the $5^{\text {th }}$ NC Cavalry. That was just two months before their first child, William Edgar, was born. Three other sons were born after the war. 


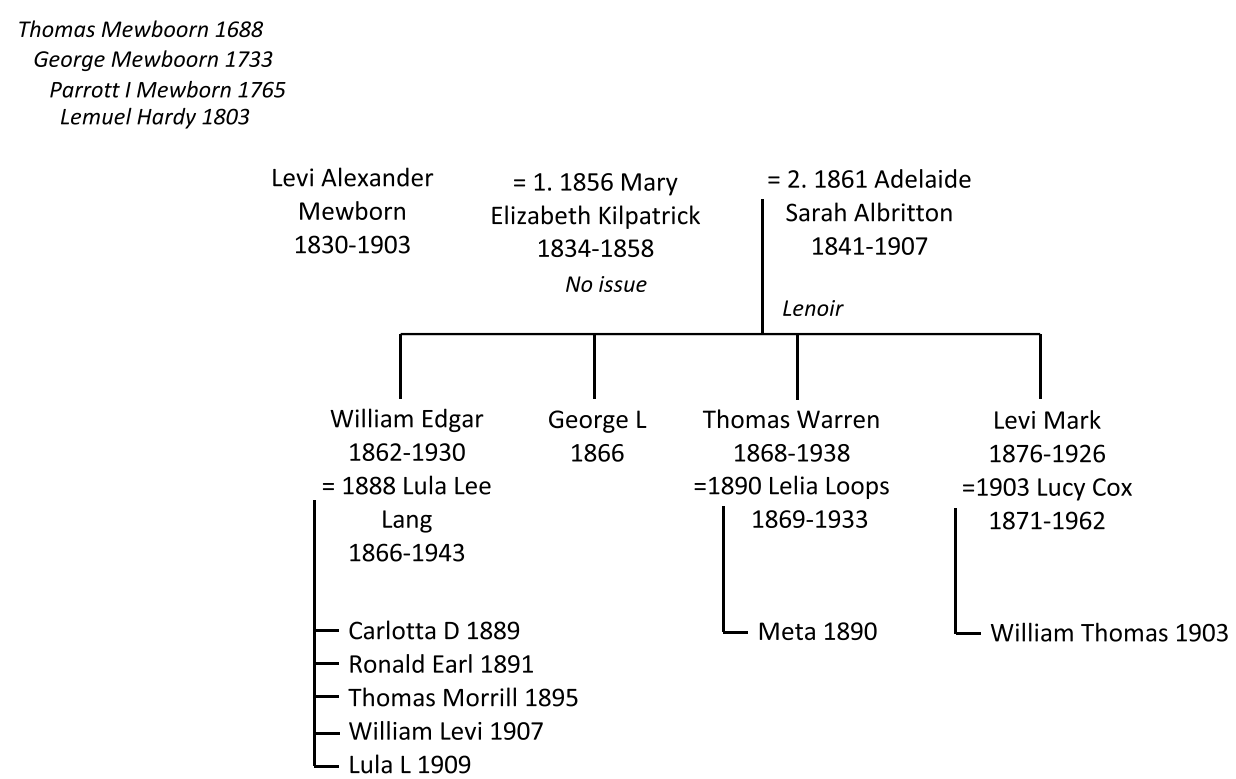

Figure 48. Descent from Levi Alexander Mewborn, 1830, generations 5-7.

Of the four sons, three are known to have had children:

- William Edgar was born on the $1^{\text {st }}$ of September 1862 at Greene and married Lula Lee Lang at Pitt in December 1888. William worked as a travelling salesman but continued to live at Kinston. They had seven children of whom five lived, including three sons to continue the line. All three sons married, and Ronald and Morrill are known to have had families.

- Thomas Warren was born on the $31^{\text {st }}$ of March 1868 and married Lelia Loops at Lenoir in June 1890. Thomas was a merchant at Lenoir and had one daughter.

- Levi Mark was born on the $8^{\text {th }}$ of April 1876 at Lenoir. He married Lucy Cox in 1903 and made his living as a salesman. They had one son to carry on the name.

Lemuel Hardy 1836, L5.1.4.2: G5-G7 - Pitt, NC

Here we have the second Lemuel Hardy marrying a second Louisa Kilpatrick. The second Lemuel was born on the $26^{\text {th }}$ of March 1836 at Greene. His marriage to Louisa Kilpatrick has not been found but their first child was born in 1859 and they farmed at Pitt where they had six children before Lemuel's death in 1872. Lemuel also fought in the Civil War and became a Corporal in the $41^{\text {st }}$ Regiment. He was just 36 when he died so the children were all placed under the guardianship of J. B. Kilpatrick. 


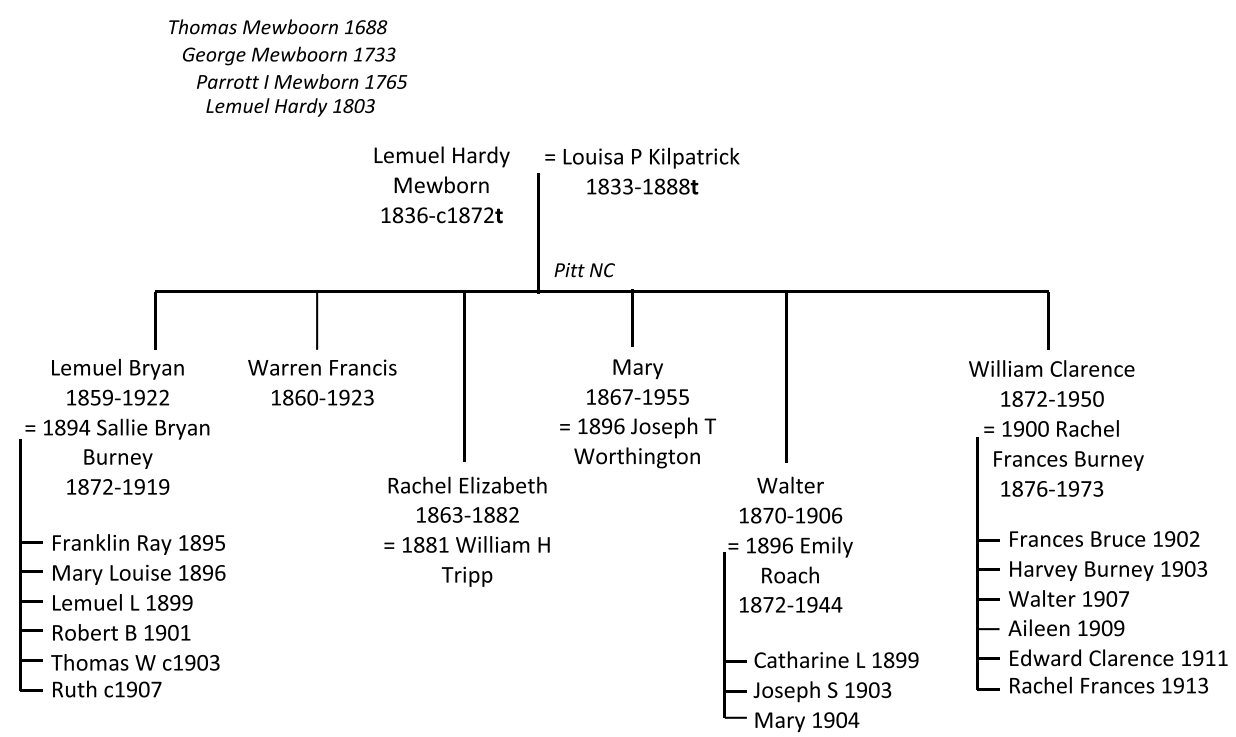

Figure 49. Descent from Lemuel Hardy Mewborn, 1836, generations 5-7.

Three sons married and had families:

- Lemuel Bryan was born on the $7^{\text {th }}$ of February 1859 and married Sallie Burney at Pitt in 1894. They farmed first at Swift Creek but by 1910 Lemuel was a mail carrier at Grifton. There were six children including four sons to potentially carry on the name.

- Walter was born at Pitt on the $4^{\text {th }}$ of August 1870 and married Emily Roach there in 1896, becoming post-master at Johnsons Mills later that year. They had three children, but their only son died at one year old.

- William Clarence was born on the $15^{\text {th }}$ of September 1872. He married Fannie Burney (sister of Lemuel's wife Sallie) in 1900 and they had six children, including three sons, while farming at Swift Creek. By 1920 they were at Ayden and by 1940 at Grifton. Brother Warren ('Frank') was with them in 1900 and 1910. By 1920, at Ayden, Clarence had also become a post-master. It seems that the brothers all aspired to the postal service.

\section{LINE 6 - from John Mewboorn c1734 - with some uncertainties}

After Thomas's will, John appears next in the early tax list for Bertie of 1757 and then in the colonial tax list for Bertie County of $1768{ }^{59}$ by which time he was the only one of Thomas Mewboorn's sons left in Bertie. By the time of his death, though, he was in South Carolina.

He left a will in 1800. The will identifies four children including two sons. Descent from John, the younger son, through his son, Eli, is clear. Descent from the elder son, Joshua, and his son, William, is much less clear. 
Thomas Mewboorn 1688

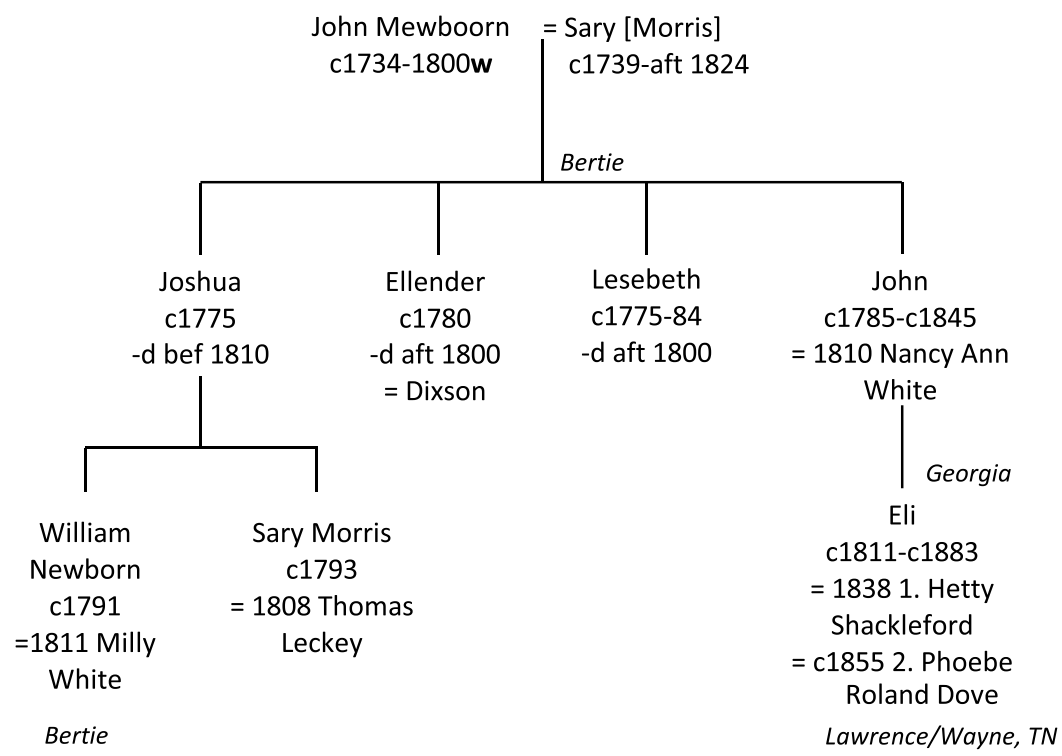

Figure 50. Descent from John Mewboorn, c1734, generations 2-4.

A transcription of the main body of John's will is as follows:

“... I John Mewboorn of S South Caroliner...

first I give and bequeath to Sary my Dearly beloved Wife all my horsses and Cattle and hogs and all my houssen Stuf her life time and then for the household property to be Equally devided between my children my fore Children John Mewboorn Joshua Mewboorn and Lesebeth Mewboorn Ellender Dixson also I give to my Son Joshua Mewboorn too hundred and fifty acors of land to his airs an and assigns forever

when I likewise Constitute and and ordain the Executor of this my last Will and also I give to my gren Son William Mewboorn fifty acors of land on the South Side of little linches Creek and to my dayter Sary morris I give her five Shillings Sterlings money

to Be my last Will and testament in Witness whereof I have hereunto Set my hand and Seal this the first day of October in the Year of our lord one thousand Seven Hundred Eight 1800".

John's will was made at Kershaw, SC. It names his four children as John, Joshua, Lesebeth and Ellender and a grandchild, William, as well as a 'dayter' Sary Morris.

Alarm bells ring at this point. We cannot be sure that this John in South Carolina is the John from Bertie in North Carolina. The principal clue is that he calls himself (and his children) Mewboorn - an exceptionally rare name known only among the descendants of Thomas Mewboorn. Despite that, some uncertainty must remain. Further uncertainty arises from the fact that in 1800 at Kershaw there is also an entry for an Isaac Newbourn aged 45 and over - so born before 1755 . Who he is remains a complete mystery and there is no firm reason to suspect a link.

Accepting that the Mewboorn will is for the son of progenitor Thomas, then there is an issue over people appearing in the census that year and the will, the census having been taken three months before the will was written. John appears in the 1800 census at Kershaw, SC, as John Newburn - though that spelling is most likely down to the enumerator. The entry for his household identifies 3 males under 10, 1 between 1625, and 1 between 26-44; 1 female under 10, one $16-25$ and 1 who was 45 and over.

Joshua appears to be the eldest son from the wording of the will, therefore should be the 26-44 male (therefore born 1774 or earlier), while grandson William must be a son to Joshua, and under 10 (so born 1790-1800). Sary Morris is perhaps a granddaughter and, therefore, also a child to Joshua and under 10. Ellender was evidently married to a Dixson so would not be among those counted in the census (and may even be the oldest child). Lesebeth therefore must have been the 16-25-year-old female (therefore also born between 1775-1784), while son John must have been the 16-25 male (1775-1784. That leaves two under-ten males from the census who are not mentioned in the will, who may have died before the will was made, or were not close relatives. 
A flaw in this argument is that, as described here, John himself is missing from the enumeration. We would expect him to be listed as a male over 45 , but there is no such entry. The female over 45 is a match for expected wife Sary. Errors in the census returns are not uncommon and a simple omission is how this has been interpreted.

Sary (not John's widow, but his 'dayter') apparently married Thomas Leckey in 1808. If she was 15 at that point, then she was born around 1793. That puts her father's birth towards the earliest indicated by the census - 1775 - for him to be married around 17 to 18 .

There is a Sarah as head of a household in the 1810 and 1820 censuses at Chowan. She is taken to be John's widow (and we may speculate that her maiden name was Morris if a grand daughter was named Sary Morris). In 1810 there are two males in the 16-25 bracket (therefore born between 1785-1794), who can be equated with son John with a birth around 1785 and grandson William who we have placed at 1791.

\section{Joshua 1775, L6.1: G3-G5 - Bertie, NC}

John's will has been interpreted as showing that Joshua was his eldest son and that he in turn had a son, William, in about 1791. Joshua does not appear as a householder in any census though it seems likely that he was numbered in the 1800 census at Kershaw with his father. His mother Sarah then appeared as a householder in censuses at Chowan in 1810 and 1820 though none of the young males with her seem of the right age to have been Joshua (unless one of the ages given in 1810 is incorrect).

There is a Joshua in the 1810 census at Chowan, but the age band suggests he is more likely to be Joshua Wilson Mewborn of 1785. Similarly, a lone Joshua at Chowan in 1830 is again believed to be Joshua Wilson. The Sara who died in 1824 and whose goods were auctioned off is taken to be Sara Bains the wife of Joshua Wilson and not Sara the wife of John (Joshua bought many items at the auction; the only other Mewborn purchaser was an Ann who bought an old bible - maybe she was Joshua's mother).

Son William married Milly White at Chowan in 1811 (and his uncle John had married Nancy Ann White just a year earlier). Thomas Leckey, Sary Morris's husband, was bondsman - which offers some supporting evidence that we have the right William. Censuses from 1850 to 1880 at Bertie have a Milly Newbern and in the first three a William appears with her. However, the ages they give are extraordinary (they are, however, said to have been unable to read or write and also may not have had any clear notion of their ages). In 1850 William is given as 40 and Milly (Emily) 55 ; in 1860 William is said to be 98 and she $88 ; 1870$ has them as 90 and 80; in 1880 a widowed Milly is reckoned to be 90 - perhaps the most plausible of all the ages. If we accept that it is the same William and Milly in each of these censuses, then seven children are mentioned. However, their recorded ages are as suspect as those of their parents with the eldest two apparently not appearing until nine years after William's marriage to Milly.

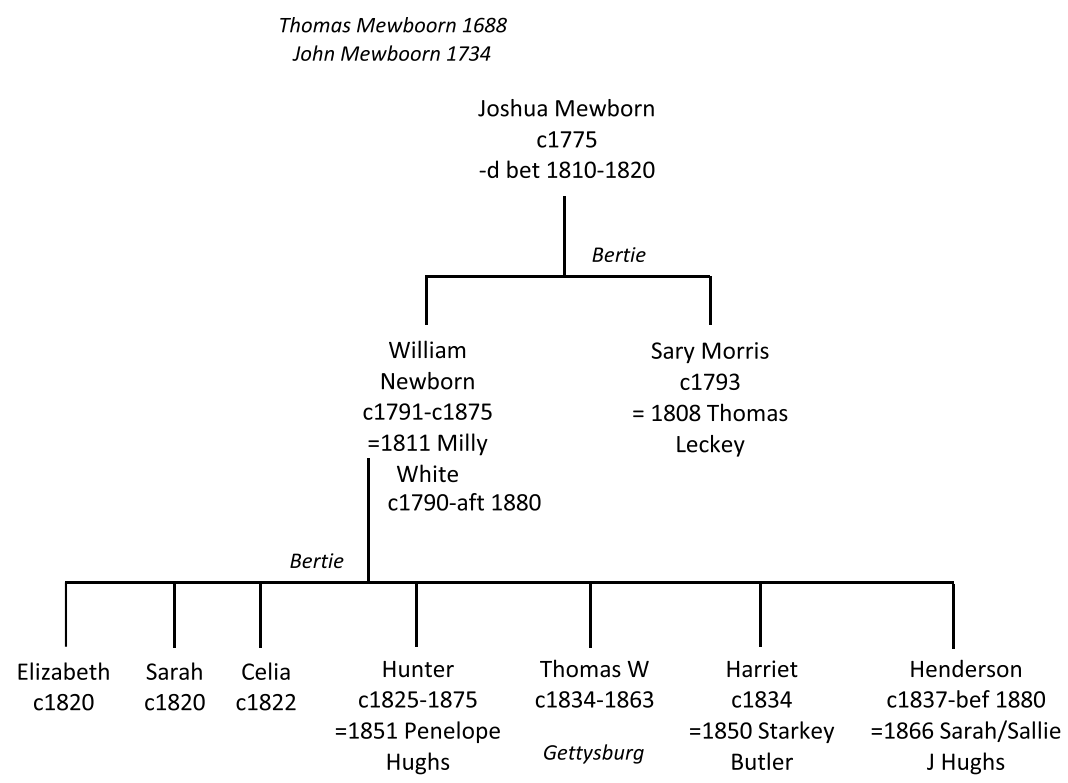

Figure 51. Descent from Joshua Mewborn, c1775, generations 3-5. 
William had three sons:

- Hunter is dealt with below.

- Thomas $\mathrm{W}$ enlisted in the Confederate Army on the $10^{\text {th }}$ of June 1861 at Coleraine, joining Company $\mathrm{F}$ in the $5^{\text {th }}$ Regiment, North Carolina Infantry. He was taken prisoner at Gettysburg on the $1^{\text {st }}$ of July 1863 and died of smallpox while a prisoner on the $20^{\text {th }}$ of October 1863.

- Henderson is also dealt with below.

Hunter c1825, L6.1.1.1: G5-G6 - Bertie, NC

Hunter is the eldest son of Joshua's eldest son, William. He appeared with his own household at Colerain in Bertie in 1860, then at Whites, Bertie in 1870.

Hunter enlisted on the Confederate side in the Civil War on the $18^{\text {th }}$ of June 1861 in Co. F, North Carolina 5 th Infantry Regiment and was mustered out on the $16^{\text {th }}$ of January 1862 at Petersburg, VA. He re-joined later to the 67 th NC Infantry and was captured and became a prisoner of war at Plymouth on the $17^{\text {th }}$ of December 1863 . He was exchanged on the $13^{\text {th }}$ of February 1865.

No death records for him or wife Penny have been found but Penny was a widow in 1880.

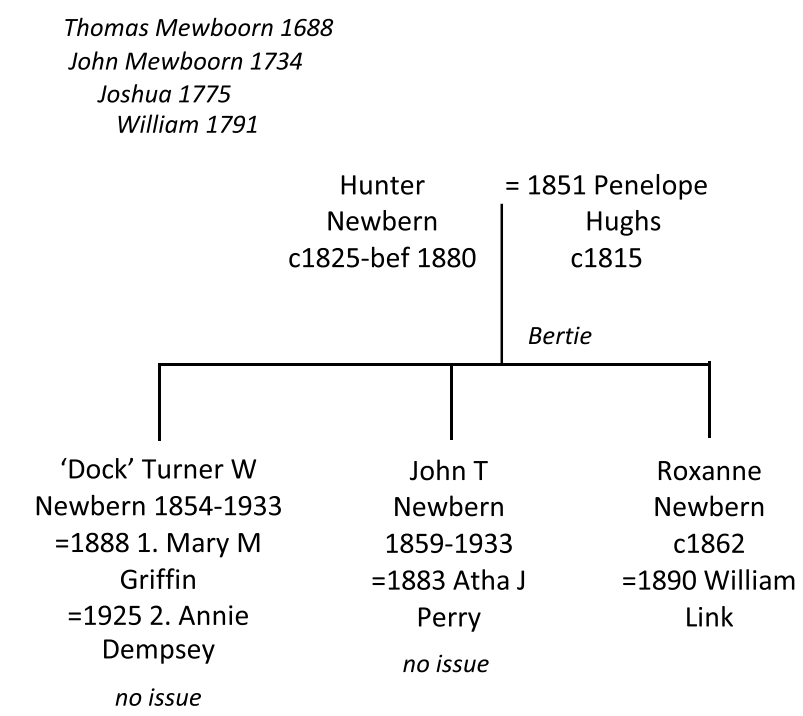

Figure 52. Descent from Hunter Newbern, 1825, generations 5-6.

Hunter's sons, Turner and John, continued farming at Whites but, though both married, neither had children so this line went no further.

Henderson c1837, L6.1.1.3: G5-G6 - Bertie, NC

Henderson enlisted on the $1^{\text {st }}$ of June 1861, the first of the brothers to do so and the first to join the $5^{\text {th }}$ Regiment, North Carolina Infantry. He was wounded at Williamsburg and taken prisoner on the $19^{\text {th }}$ of May 1864 . He was released on the $15^{\text {th }}$ of May 1865 . A year later he married Sallie Jane Hughs, a sister of brother Hunter's wife Penelope. By 1880 his wife is recorded as a widow at Whites in Bertie. 


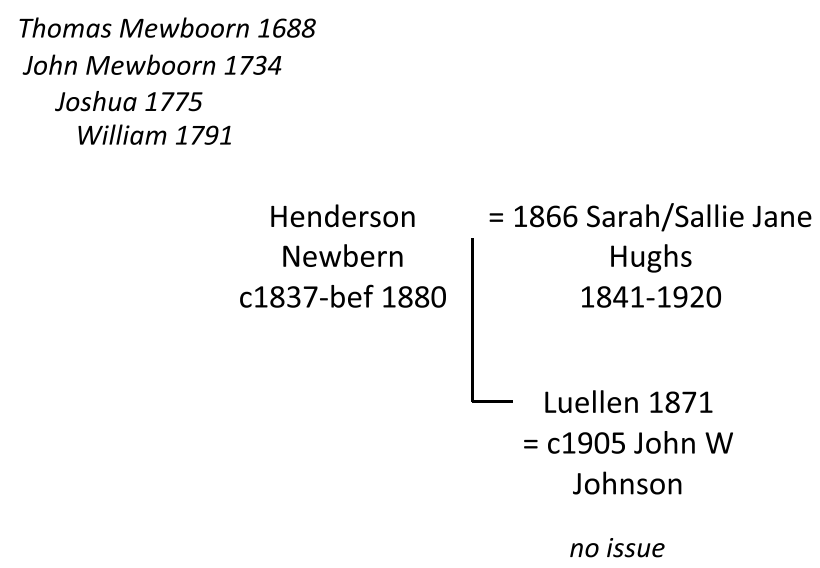

Figure 53. Descent from Henderson Newbern, 1837, generations 5-6.

Sallie Jane appears in the family census in 1850 as Sarah and again as Sarah in 1880 and 1900, with her only child, daughter 'Lewellen'. She is then recorded at Edenton in 1910 and 1920 as Sallie J, living with her married daughter (who by then preferred Lue or Luellen).

\section{John 1785, L6.2: G3-G5 - Bertie to Tennessee}

The line from John junior in Line 6 takes us via son Eli and his two marriages to more modern times. We know that John migrated since Eli invariably describes himself as born in Georgia, though he first appears as a householder at Lawrence, Tennessee. His mother, Nancy appears in Eli's household at Lawrence in 1850, but by then there was no trace of John.

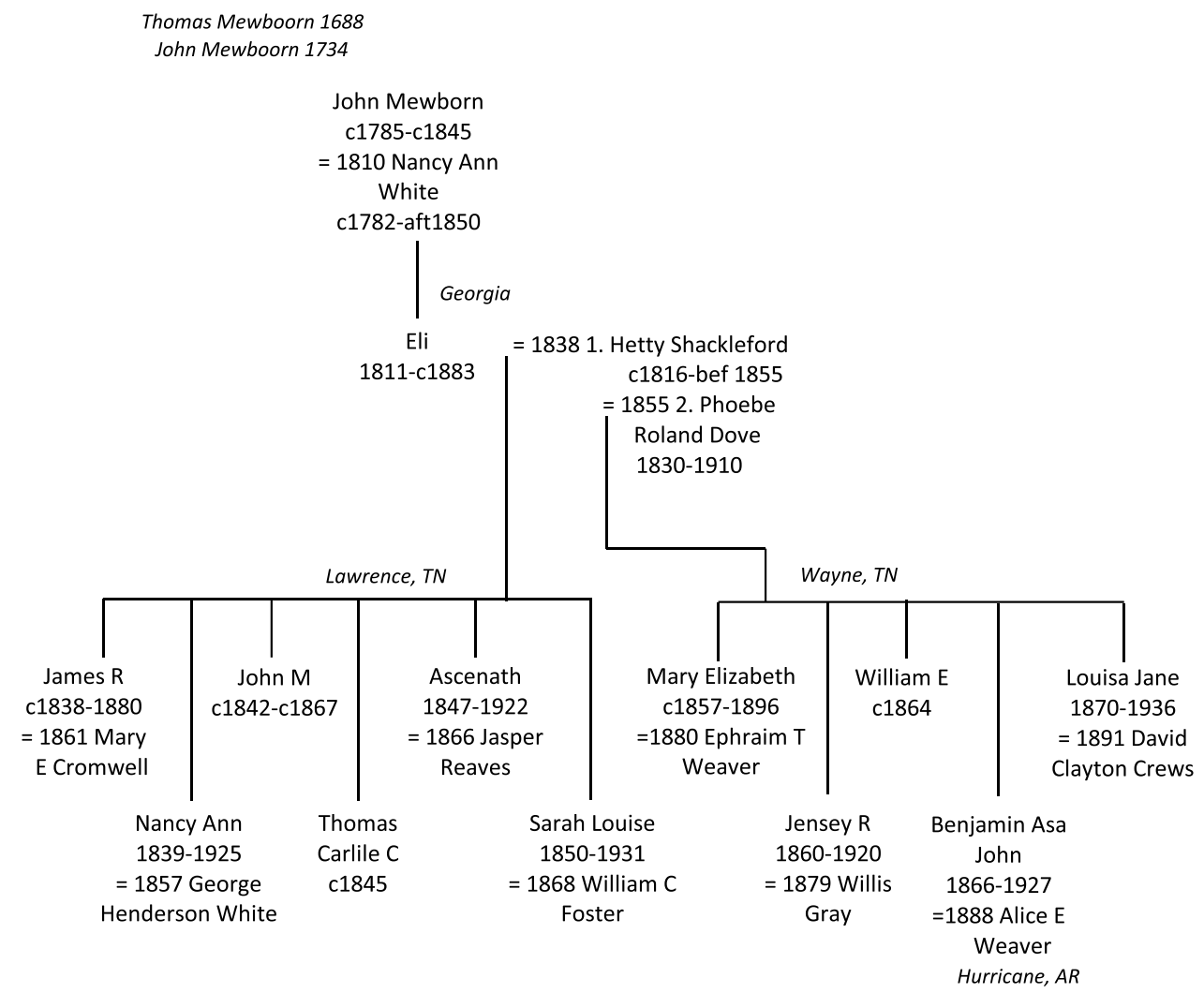

Figure 54. Descent from John Mewborn, 1785, generations 3-5.

Eli married twice and had children, including sons, from both marriages - firstly at Lawrence then at Wayne. We presume he died at Wayne, but no record has been found. 
James R 1836, L6.2.1.1: G5-G7 - Wayne, TN

James $\mathrm{R}$ farmed at Wayne and raised eight children. He appears first in censuses at Lawrence with his parents and then with them at Wayne in 1860. He married in 1861 and continued farming at Wayne, appearing in the 1870 and 1880 censuses before dying in 1880.

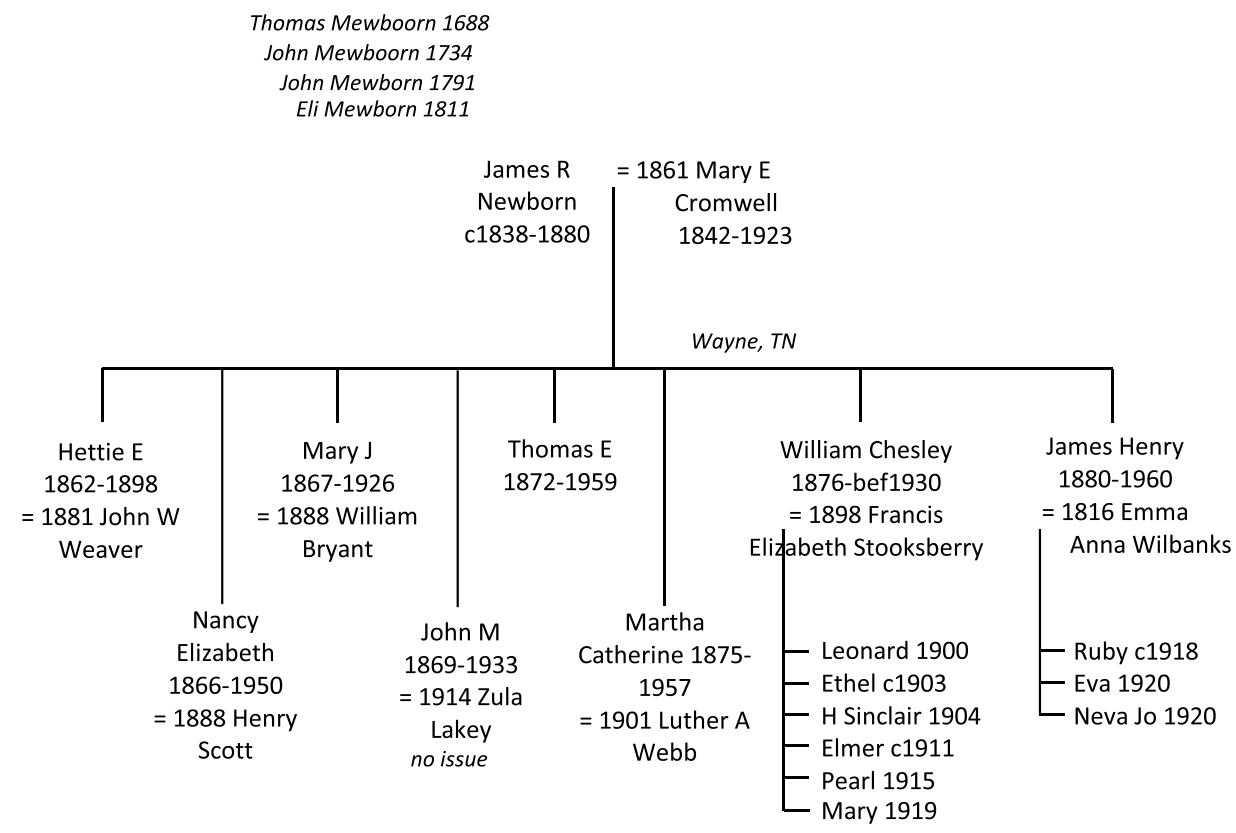

Figure 55. Descent from James R Newborn, 1838, generations 5-7.

Of James R's four sons, only William Chesley had sons who may have perpetuated the name. After William's marriage to Lizzie Stooksberry, in 1898, they first settled and were farming at Hardin in 1900. By 1920, though, they were back in Wayne. Lizzie was on her own with the family by 1930 (and lived to 1957 still at Wayne) but Chesley's death and burial have not been found.

Benjamin Asa John 1866, L6.2.1.5: G5-G7 - Greene, AR

Benjamin was born at Wayne to Phoebe Dove and by 1880 was farming with his father. He married Alice Weaver at Hardin, TN in 1888 but by the time of their third child in 1896 they had moved to Greene, Arkansas and were in censuses there in 1900 and 1910 (listed latterly as 'Jay'). By 1920 he had moved the family to Virginia, Missouri, but was buried back at Greene in 1927. Alice lived for a while with daughter Leiron at Archer, Texas but was buried at Greene with Benjamin. 


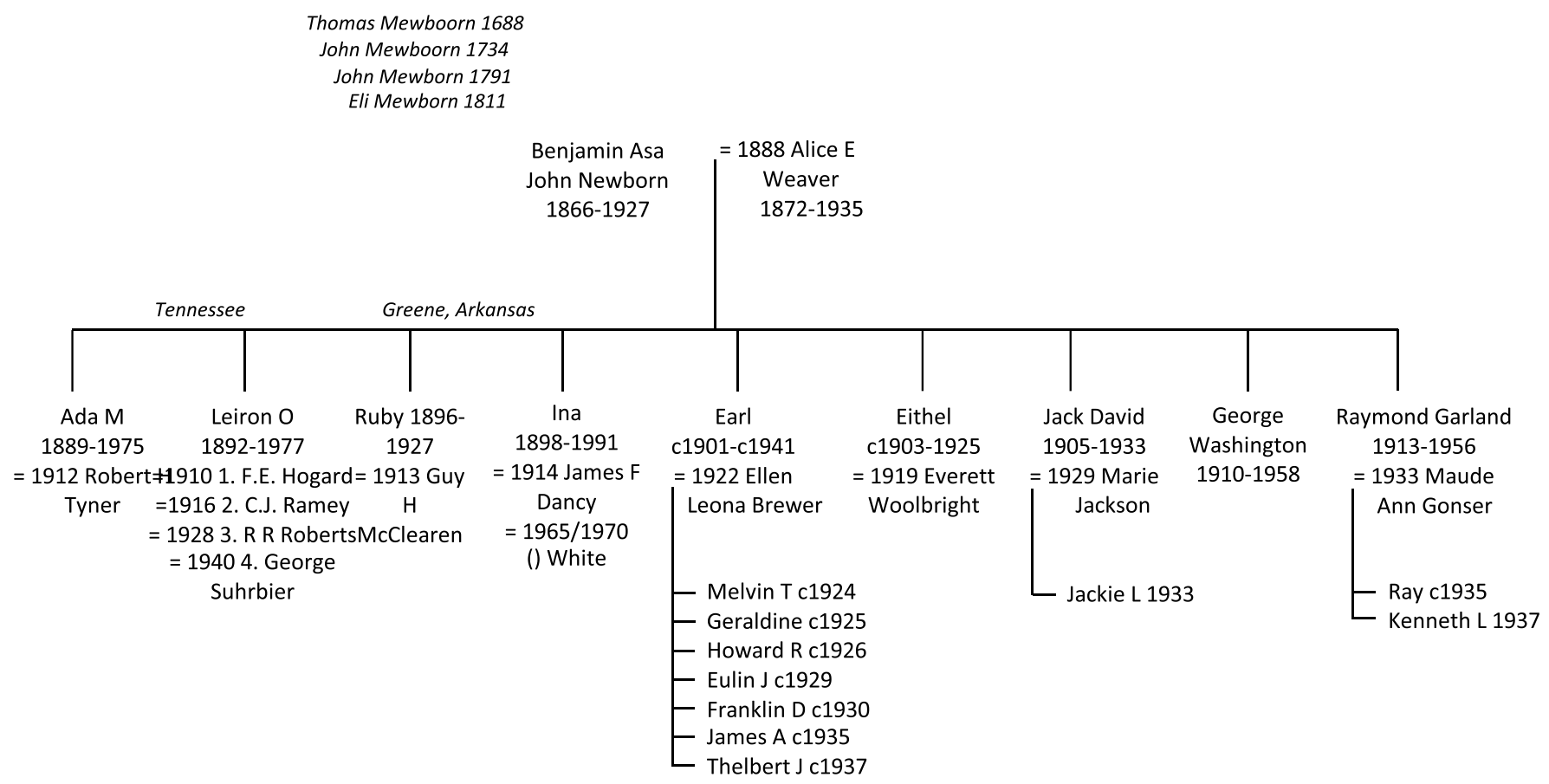

Figure 56. Descent from Benjamin Asa John Newborn, 1866, generations 5-7.

There were four sons, and seven grandsons to continue the line:

- Earl Mewborn was born at Greene and continued to live in various parts of the county. He was married at Marmaduke in 1922 to Ellen Leona Brewer, and was farming at Friendship in 1930 and at Breckenridge in 1940. Six of their seven children were sons.

- Jack David was born on the $13^{\text {th }}$ of April 1905 at Greene then moved with the family to Missouri. He married Marie Jackson in 1929 back at Greene then tried his hand at auto production, and running a boarding house at Flint, Genesee, Michigan (where General Motors was founded). Marie and Jack had a son, Jackie, but Jack then died aged just 27 back at Greene.

- George Washington served in the military police in WW2 and is not known to have married. He died in Toledo but is buried back at Marmaduke, Greene.

- Raymond Garland was born on the $19^{\text {th }}$ of September 1913 at Greene. In 1930 after his father's death he was living with his mother and with married sister Leiron Roberts at Megargel in Texas. In 1933 he married Maude Ann Gosner back in Arkansas where they had two sons. There must have been a divorce around 1940 since Maude and the children were then living with her mother and she married again in 1945. Raymond then lived in California, dying in San Francisco in 1956.

\section{Remaining Mysteries}

The descent from Thomas Mewboorn plotted in these pages is extensive but is unlikely to be complete. There are breaks in the records, particularly during the dark ages of the early $19^{\text {th }}$ century where early census records indicate possible unnamed male descendants but lack continuity through to 1850 where all members of the household are first given names. This means there may well be living descendants of Thomas Mewboorn who cannot currently be linked back to him.

New records may emerge and transcripts from as yet unpublished family bibles may turn up to provide evidence of bridges. Autosomal DNA studies could be very valuable in this context, but few tests are known to have been carried out by family members.

A number of families emerge from these uncertain times that have characteristics which raise hope that they may be descended from early times and Thomas Mewboorn. One important characteristic is a continued presence in North Carolina. It is tempting to think that such a presence indicates roots in the state. The alternative is that unrelated people migrated into the state and took this relatively rare name or one of its variants - that seems unlikely, though still not impossible. Another characteristic is adherence to one of the surnames, particularly Mewborn. There are fairly obvious reasons for a new migrant to adopt Newborn as a name, or even Newbern (in a North Carolina context), but Mewborn would be an odd choice (though not so later at the abolition of slavery). 
Mysteries exist where it has not been possible to move forward from certain points; others exist where families have suddenly appeared, particularly from 1850 and particularly where they appear in places where there are already descendants from Thomas. Close geographical association for holders of a rare name commonly indicates some relationship.

\section{Census Orphans}

A number of people turn up in North Carolina in the 1850 Federal Census who cannot be linked back to the current set of lines of direct descent. Some may have been recent migrants into North Carolina, but it seems reasonable to imagine that some are indeed descendants from Thomas. However, which is which, and where they link to the main lines are matters that have not been resolved. Note, there are no orphans with the ' $\mathrm{M}$ ' spelling of the name! That, of course, reduces the likelihood of these orphans being Mewboorn descendants.

Men appearing in the 1850 census with North Carolina births and a fairly early year of birth, but with unknown links back to the Thomas Mewboorn lines are:

1801, Thomas Newbern - Davidson, Tennessee

1827, Joseph Newbern - Davidson, Tennessee

1835, John Newborn - Davidson, Tennessee along with Edy Newborn, 50, both in the family of Nancy Sawyers, aged 19.

This Davidson group could be interpreted as two generations - Thomas and Edy (as a widow of a possible brother of Thomas's) with Joseph as a child of Thomas and John and Nancy as children of Edy.

1849, John H Newbern, aged 1, at Lee, Virginia, in the family with Margaret Measles, 47. He could be a son of Sumner Newbern.

1801, Hickman Newborn - Campbell, Georgia (he also appears in 1830 at Jackson, GA; 1840 at Pike, GA)

Hickman is interesting because he is found in three censuses alongside a slightly younger John (c1805 and said to have been born in Georgia), each in the same three different places in Georgia - so apparently following each other around, therefore possibly brothers.

In 1830 Hickman's age is in the 1801-1810 bracket; in 1840 it is 1791-1800; in 1850 it equates to 1802 . In 1860 he was at Campbell, GA listed as 61 (= 1799) and in 1870 it is 70 (=1800). Overall, 1801 fits best to these dates. He is too young, as is Thomas at Davidson, TN, to fit into either Line 1 or Line 2. Could he, or either, be a descendant of Thomas Jnr in Line 4 from Moses? There is simply no evidence at present.

Two other names of men appear in the 1860 census who had not previously been known. They are:

1811, Ann (Aron?) Newbern - Red River, Texas

1820, William Newburn - Norfolk Virginia

There is nothing to say how or whether they fit into the Mewborn story.

By 1850 it is, of course, possible that we are seeing people as householders in the censuses who are second or even third generation descendants of some Mewboorns who moved west at an early time, from the late $18^{\text {th }}$ and early $19^{\text {th }}$ centuries. They would, therefore, not have been born in North Carolina, so their origins are even more difficult to trace - it was not until 1880 that father's and mother's places of birth were included in the census and by then it is usually too late to give clues to the origins of early orphans.

\section{Future opportunities}

In several cases we have early censuses that identify males in the households of known Mewborn descendants, but for whom we cannot suggest a name. These are typically from the early $19^{\text {th }}$ century, too soon to hope for a bridging of the gap to 1850 . Many may have died young; some may have migrated to places that have yet to be recognized as part of the Mewborn diaspora. From their various parents, they include: 
Line 1, from Dr William Jones Newbern c1790:

Male c1812; Male c1818; Male c1820; Male c1829; Male c 1832

Line 1, from Thomas Jones Newbern, c1797:

Male c1809; Male c1812; Male c1815; Male c1821; Male c 1820

Line 1, from Dr James Newbern, c1801:

Male c1818; Male c1819

Line 2, from George Newbern, c1758:

Male c1786; Male c1790

Line 2, from William Newbern, c1782:

Male c1827; Male c1833; Male c1836

Line 2, from John Newbern, c1800:

Male c1830; Male c1833; Male c1836

These wraiths from the past are included largely for the sake of completeness in this study. The best that can be said about them is that the approximate dates for these male household inhabitants cover the first third of the nineteenth century fairly thoroughly. If a case is to be made for including some new person into the Mewborn pattern of descent, there is ample choice from among these options. However, without new sources of evidence it will be difficult to make a case.

\section{Conclusion}

This monograph has traced descent from Thomas Mewboorn, born possibly around 1688. Thomas was an early settler in North Carolina, having been there from at least 1716 and possibly having arrived along with the Palatine settlers in 1710. A critical commentary on his origins and arrival is provided. He was a blacksmith and became a plantation owner at Bertie before his death in 1749. Six sons took the Mewboorn name forward, though with various changes in spelling over time.

Descent in all six lines is traced in varying degrees, though mostly to the seventh generation. Wherever possible that descent is based on documentary sources, though in some areas of uncertainty hypotheses are developed based on probabilities where links are not clear. A technique for assessing patterns based on age and sex across the set of early Federal censuses between 1790 and 1840 has been developed and supports some of the hypotheses. The outcomes also demonstrate patterns of migration over a 200-year period.

This study introduces clarity to the genealogy and spread of a family of early American settlers. By having proceeded to the seventh generation, descent is shown to about the $20^{\text {th }}$ century so it should be relatively easy for other scholars to continue tracing pedigrees to the present day.

\section{References}

These references are largely to secondary sources cited in this work. References for the personal facts gleaned from primary sources and used in constructing the tree of descent from Thomas Mewboorn can be found within the online tree hosted by the Guild of One-Name Studies (www.mewborn.one-name.net). Those references are not included here as there are close on 1,700 of them and they would add a further 90 pages.

1. Brayton, John Anderson. 2014. Order of First Families of North Carolina - Ancestor Biographies. Vol. 2. Baltimore, MD: Otter Bay Books. pp. 215-216.

2. Hanks, Patrick ed. 2003. Dictionary of American Family Names. Oxford: Oxford University Press.

3. Oliver, Marjorie Elizabeth Sutton. 1974. Suttons of England and North Carolina, USA 1620-1974. Greenville, NC: National Print Co. p. 21.

4. Macdonald, Ian G. 2018. Mewburn and Meaburn - the people - their family tree. http://mewburn.one-name.net.

5. Before the $18^{\text {th }}$ century only three records with a Mewborn spelling are known in England, two baptisms in Co. Durham, for William son of Nicholas in 1542 at Egglescliffe, and for Arthur son of Thomas in 1642 at Chester-le-Street (and in each case other spellings are used for other siblings, illustrating the fluidity of spelling at the time), and a marriage at Stokesley, north Yorkshire in 1677 between a James and Ann Appleby. Mewboorn does not show up.

6. Testamentary records. USA. Bertie, North Carolina. 1719 [sic]. MEWBORN, Moses. Collection: North Carolina, Wills and Probate Records, 1665-1998. www.ancestry.com.

7. Mewborn, Michael Dennis. 2010. The Descendants of Moses Mewboorn of England. E-book: Blurb. www.michaelmewbornart.com.

8. Boddie, Mrs John Bennett. 1978. Historical Southern Families, vol. XXII. Baltimore: Genealogical Publishing Company. pp. 22-25.
9. Otterness, P. 1999. The 1709 Palatine Migration and the Formation of German Immigrant Identity in London and New York. Pennsylvania History: A Journal of Mid-Atlantic Studies. 66. Explorations in Early American Culture. pp. 8-23.

10. McCarthy, Bonnie. 2015. Mewborn Family Tree. https://www.ancestry.co.uk/familytree/person/tree/73061182/person/34447128242/facts.

11. A possibly interesting source, but not an accessible document. Worldcat.com knows of no library in the world that has a copy.

12. DeGraffenried, Thomas P. 1925. History of the DeGraffenried Family from 1191 A.D. to 1925. New York: privately published. https://archive.org/details/ historyofdegraffoograf

13. Jones, Victor T. 2000. Swiss and Palatines to New Bern. A List of Known Persons who left Switzerland and Germany to settle in New Bern, North Carolina in 1710. New Bern, North Carolina: New Bern-Craven County Public Library. http://newbern. cpclib.org/research/settlers.htm.

14. Jones, Victor T. Jr. 1997. Swiss-Palatines to New Bern: A List of Known Persons Who Left Switzerland and Germany to Settle New Bern, N.C., in 1710. The North Carolina Genealogical Society Journal. 23(1). pp. 3-10.

15. Tritton, Alec. 2012. Palatine Migration into England. Exodus website. https://www exodus2013.co.uk/palatine-migration-into-england/ 
16. Collins, Donald E. 2006. 'Swiss and Palatine Settlers'. In: Powell, William S. ed. 2006 Encyclopedia of North Carolina. Raleigh, North Carolina: University of North Carolina Press.

17. Wikipedia. 2020. German Palatines. https://en.wikipedia.org/wiki/German_Palatines.

18. Rohrbach, Lewis B. 2003. The 1710 Von Graffenried Settlement Of New Bern, North Carolina. Swiss American Historical Society Review: 39(2). pp. 5-48. https://schola sarchive.byu.edu/sahs_review/vol39/iss2/3.

19. Beine, Joe. Palatines from Germany to England in 1709 [names extracted from the New York Genealogical \& Biographical Record. Vol. 41. pp. 10-19; Published by the New York Genealogical \& Biographical Society, New York (January 1910)]. https:// www.genesearch.com/genealogyrecords/1709palatines/may.html.

20. MacWethy, Lou D. (comp). 1998. The Book of Names: Especially Relating to the Early Palatines and the First Settlers in the Mohawk Valley. St Johnsville, NY: The Enterprise and News. http://www.threerivershms.com/nameshunter.htm.

21. Beine, Joe. Palatine Ships to New York in 1710. https://www.genesearch.com/genea logyrecords/newyorkpalatines $1710 . \mathrm{html}$

22. Otterness, Philip. 2004. Becoming German. The 1709 Palatine Migration to New York Ithaca and London: Cornell University Press.

23. Brayton, John Anderson. 2014. Order of First Families of North Carolina - Ancestor Biographies. Vol. 2. Baltimore, MD: Otter Bay Books. pp. 215-216.

24. Hathaway, James Robert Bent. 1900. The North Carolina Historical and Genealogical Register. Edenton, NC: J R B Hathaway.

25. Early Tax List. Chowan County, North Carolina. 1721. MEWBORNE, Thomas Collection: North Carolina, Compiled Census and Census Substitutes Index, 1790 1890. www.ancestry.com.

26. Deeds. Chowan County, North Carolina. 1722. MEWBORN, Thos., grantee Collection: Chowan County, North Carolina Cross Index to Deeds - Grantees 1696-1878. www.ancestry.com.

27. Deeds. Chowan County, North Carolina. 1729. MEWBORN, Thos., grantee. Book C, p 612. Collection: Chowan County, North Carolina Cross Index to Deeds - Grantees 1696-1878. www.ancestry.com

28. Deeds. Chowan County, North Carolina. 1729. MEWBORN, Thos., grantor. Book C, p. 629. Collection: Chowan County, North Carolina Cross Index to Deeds - Grantees 1696-1878. www.ancestry.com

29. Deeds. Chowan County, North Carolina. 1732. MEWBORN, Thos., grantor. Book C, p 694. Collection: Chowan County, North Carolina Cross Index to Deeds - Grantees 1696-1878. www.ancestry.com.

30. Fouts, Raymond Parker. 2007. 1720 Acreage List for Chowan Precinct. North Carolina Genealogical Society Journal. 33(1). p. 37.

31. North Carolina Visitor Center. 2019. History of Chowan. Website. http://ncvisitorcen ter.com/Chowan.html.

32. Wikipedia. 2020. Edenton, North Carolina. https://en.wikipedia.org/wiki/Edenton, _North_Carolina

33. Testamentary records. USA Bertie, North Carolina 1749 MEWBOORN, Thomas. Collection: North Carolina, Wills and Probate Records, 1665-1998. www.ancestry. com.

34. Testamentary records. USA. North Carolina. 1717. GOREHAM, John. Collection: North Carolina, Wills and Probate Records, 1665-1998. www.ancestry.com.

35. Hathaway, James Robert Bent ed. 1900. The North Carolina Historical and Genealogical Register. 1(3). Edenton, North Carolina: J.R.B. Hathaway. p. 346.

36. Testamentary records. USA. North Carolina. 1717. GOREHAM, John. Collection: North Carolina, Wills and Probate Records, 1665-1998. www.ancestry.com
37. Watson, Alan D. 1979. The Colonial Tax List, Table 1, Bertie Co., NC, Tax List, 1768 North Carolina Genealogical Society Journal. 5(4). p. 228

38. Testamentary records. USA. Bertie, North Carolina. 1774. MEWBOORN, Nicholas. Collection: North Carolina, Wills and Probate Records, 1665-1998. www.ancestry. com.

39. Marriages. USA. Chowan, North Carolina. 1788. PRICE, James Seth and NEWBERN, Elizabeth. Collection: North Carolina Marriage Records, 1741-2011. www.ancestry. com.

40. Marriages. USA. Chowan, North Carolina. 1791. PARKER, Seth and PRICE, Elizabeth Collection: North Carolina Marriage Records, 1741-2011. www.ancestry.com.

41. Testamentary records. USA. Bertie, North Carolina. 05 November 1815. McDOWELL, Stephen. Collection: North Carolina, Wills and Probate Records, 1665-1998. www. ancestry.com

42. Winslow, Raymond A. Jr. 1999. 1815 Tax List of Bertie Co., N.C. North Carolina Genealogical Society Journal. 25(4). p. 367.

43. Ainsworth, F. C, Brig Gen and Kirkley, J.W. 1901. The War of the Rebellion: A Compilation of the Official Records of the Union and Confederate Armies. Series II. Washington: Government Printing Office. p. 4.

44. Service records. USA. Fayette, Tennessee. 1890. NEWBERN, William W. Collection: 1890 Veterans Schedules. www.ancestry.com.

45. Winslow, Raymond A. Jr. 1989. Five "Lost" Tax Lists of Chowan County, N.C., 17841799. North Carolina Genealogical Society Journal. 15(4). p. 206.

46. Testamentary records. USA. Bertie, North Carolina. 1817. NEWBORN, Nicholas (Mrs Dolby petition, 4 Dec 1820). Collection: North Carolina, Wills and Probate Records, 1665-1998. www.ancestry.com.

47. Testamentary records. USA. Bertie, North Carolina. 1821. NEWBERN, Nicholas. Collection: North Carolina, Wills and Probate Records, 1665-1998. www.ancestry.com.

48. Testamentary records. USA. Bertie, North Carolina. 1817. NEWBORN, Nicholas (William Bains petition, undated). Collection: North Carolina, Wills and Probate Records, 1665-1998. www.ancestry.com.

49. Testamentary records. USA. Bertie, North Carolina. 05 November 1815. McDOWELL, Stephen. Collection: North Carolina, Wills and Probate Records, 1665-1998. www. ancestry.com.

50. Winslow, Raymond A. Jr. 1989. Five "Lost" Tax Lists of Chowan County, N.C., 17841799. North Carolina Genealogical Society Journal. 15(4). p. 206.

51. Winslow, Raymond A. Jr. 1988. North Carolina Apprentice Indentures Through 1850 (Part 4). North Carolina Genealogical Society Journal. 14(1). p. 32.

52. Watson, Alan D. 1979. The Colonial Tax List, Table 1, Bertie Co., NC, Tax List, 1768 North Carolina Genealogical Society Journal. 5(4). p. 228.

53. Winslow, Raymond A. Jr. 1989. Five "Lost" Tax Lists of Chowan County, N.C., 17841799. North Carolina Genealogical Society Journal. 15(4). p. 206.

54. Roebuck, Heywood. 1975. North Carolina Colonial Corner's Inquests, 1738-1775. North Carolina Genealogical Society Journal. 1(1). p. 14

55. Hathaway, James Robert Bent ed. 1903. The North Carolina Historical and Genealogical Register. 3(1). Edenton, North Carolina: J.R.B. Hathaway. p. 447.

56. Service records. USA. North Carolina. 1776. NEWBURN, Thomas. Collection: US Revolutionary War Rolls, 1775-1783. www.ancestry.com.

57. Testamentary records. USA. Newton, Georgia. 1831. MEWBORN, Thomas. Collection Georgia Wills and Probate Records, 1742-1992. www.ancestry.com.

58. Mewborn, Ima Eula. In: 1997. website http://www.bjhughes.org/parrmew.html.

59. Watson, Alan D. 1979. The Colonial Tax List, Table 1, Bertie Co., NC, Tax List, 1768. North Carolina Genealogical Society Journal. 5(4). p. 228.

\section{ABOUT THE AUTHOR}

Dr lan G. Macdonald, MSc (Genealogical Studies), C.Eng, CITP, FBCS, is a zoologist, explorer, information engineer, quality award assessor and latterly genealogist. lan is a tutor for the University of Strathclyde's online postgraduate genealogy courses.

He was the first Chairman of the Register of Qualified Genealogists. Email: i.g.macdonald@qualifiedgenealogists.org

ORCID iD: https://orcid.org/0000-0002-7424-1259 